\author{
W \\ UNIVERSIDADE DE BRASÍLIA \\ Decanato de Pós-Graduação e Pesquisa \\ Instituto de Letras \\ Departamento de Teoria Literária e Literaturas \\ Programa de Pós-Graduação em Literatura
}

\title{
DA TRADIÇÃO INDIANISTA A QUARUP: UMA ANÁLISE DA TRANSFIGURAÇÃO DO ÍNDIO NA FORMAÇÃO DA LITERATURA BRASILEIRA
}

Dapheny Day Leandro Feitosa

Alexandre Simões Pilati

Orientador

Brasília - 2015 


\section{DA TRADIÇÃO INDIANISTA A QUARUP: UMA ANÁLISE DA TRANSFIGURAÇÃO DO ÍNDIO NA FORMAÇÃO DA LITERATURA BRASILEIRA}

Dissertação de Mestrado Acadêmico apresentada ao Programa de Pós-Graduação em Literatura (PPGL) do Departamento de Teoria Literária e Literaturas - TEL, do Instituto de Letras - IL, da Universidade de Brasília UnB, como requisito parcial à obtenção do grau de Mestre em Literatura.

Orientador: Prof. Dr. Alexandre Simões Pilati 
Dapheny Day Leandro Feitosa

\section{DA TRADIÇÃO INDIANISTA A QUARUP: UMA ANÁLISE DA TRANSFIGURAÇÃO DO ÍNDIO NA FORMAÇÃO DA LITERATURA BRASILEIRA}

Dissertação defendida no Programa de Pós-Graduação do Departamento de Teoria Literária e Literaturas do Instituto de Letras da Universidade de Brasília, para a obtenção do grau de mestre, aprovada em de de 2015, pela Banca Examinadora constituída pelos seguintes professores:

Prof. Dr. Alexandre Simões Pilati - (TEL/UnB)

Orientador e Presidente da Banca

Prof. Dr. Luiz Alberto Nogueira Alves (UFRJ)

Membro externo

Prof. Dr. Edvaldo Aparecido Bergamo (TEL/UnB)

Membro interno

Prof. Dra. Ana Laura dos Reis Correa

Suplente 


\section{DEDICATÓRIA}

À minha filha, Alice, para quem estive ausente em alguns momentos durante esta jornada. Você é para mim força motivadora de vida e de realização de sonhos. Você é a razão. 


\section{AGRADECIMENTOS}

Agradeço, primeiramente, a Deus.

À minha mãe, Doris, por me apoiar e acreditar em mim de forma incondicional.

À minha filha, Alice, por ser inspiração em tudo que tenho feito desde o seu nascimento e por me motivar a contribuir para um mundo melhor.

Ao meu marido, companheiro, amigo e amante, Emanuel, pelo amor, a paciência e o apoio. Por me ajudar com palavras de incentivo em momentos de grande desânimo.

Aos meus avós, Inês e Bosco, por contribuírem ainda na infância para pessoa que sou hoje.

Ao meu orientador, professor Dr. Alexandre Pilati, pela dedicação, as ricas contribuições e pelo exemplo de profissional que representa para mim nesta trajetória que se inicia ainda na graduação.

Aos amigos que estiveram torcendo e me incentivando com doces palavras durante esses dois anos.

À CAPES, pelo apoio financeiro. 


\section{RESUMO}

Neste trabalho buscamos retratar o panorama literário em que o índio é configurado como protagonista na literatura brasileira. Para isso, acreditamos ser necessário criar uma linha temporal que se inicia nos relatos dos cronistas e viajantes e se estende às produções literárias do período colonial. Como não poderia ser diferente observamos as aproximações e distanciamentos das produções literárias do período colonial com o indianismo do Romantismo do século XIX. Toda essa análise respalda-se na observação de como fato histórico e fato estético em diferentes momentos articulam diferentes representações dos indígenas de acordo com a dinâmica do sistema literário. Após esse resgate temporal da representação do índio, tomamos como ponto de chegada a obra de Antonio Callado, especificamente, Quarup (1967). Assim, nos propomos a analisar como essa obra difere, das anteriores que tratam da temática indígena, considerando o projeto literário de Callado que tinha como intenção ser um instrumento de desalienação e de conscientização de seus leitores diante das injustiças do país.

Palavras-chave: Indianismo, sistema, literário, transfiguração, Antonio Callado 


\begin{abstract}
In this work we aimed to present the literary scene in which the indigenous people were the main characters in Brazilian literature. Thus, we traced a time line, beginning with the first documents from the travellers and chroniclers, up until the literary production of the colonial period. We observed the similarities and differences from the literary production of the colonial period and the Indianism presented in the $19^{\text {th }}$ Century Romanticism. Our analysis, based on the relation between historical and aesthetical facts, supports the thesis that these different moments articulate different representations of indigenous people. After this analysis, we focused on the novel Quarup (1967), by Antonio Callado, trying to observe how this work differs from the previous ones that present the same theme, considering the author's literary project of being an instrument to increase the reader's awareness of the injustices of the country.
\end{abstract}

Keywords: Indianism, system, literary, transfiguration, Antonio Callado, Quarup 
INTRODUÇÃO.......................................................................................................................................... 08 CAPÍTULO 1 - OS PRIMEIROS RELATOS E A TRADIÇÃO DA LITERARIZAÇÃO DO ELEMENTO INDÍGENA …................................................................................. 15

1.1 Dos cronistas ao Arcadismo: o índio como elemento estético ………………………...16

CAPÍTULO 2 - INDIANISMO E O ÍNDIO POSSÍVEL ...................................................... 38

CAPÍTULO 3 - ANTONIO CALLADO: HERDEIRO DA TRADIÇÃO EMPENHADA 59

CAPÍTULO 4 - QUARUP: TRADIÇÃO E SUPERAÇÃO ................................................... 80

CONSIDERAÇÕES FINAIS ..................................................................................................... 103

REFERÊNCIAS BIBLIOGRÁFICAS ............................................................................ 105 


\section{INTRODUÇÃO}

Nesta dissertação temos como objetivo analisar a questão do indianismo tomando como ponto de chegada a obra de Antonio Callado, especificamente, Quarup. Esta pesquisa surgiu da necessidade desenvolver algumas problematizações a partir da minha monografia de fim de curso que tinha como tema Sociedade e Pensamento Literário: a transfiguração do índio como elemento constitutivo da nacionalidade. Assim, motivada pelo interesse em analisar como se desdobrou essa tradição que tomava o índio como elemento estético para falar sobre Brasil, debruço-me sobre a obra Quarup, de Antonio Callado, publicada em 1967, no contexto da ditadura militar.

O trabalho está dividido em quatro capítulos. No primeiro, buscamos retratar o panorama literário em que o índio é configurado como protagonista na literatura brasileira reconstruindo uma linha temporal que tem início nos relatos dos cronistas e viajantes, estendendo-se às produções literárias do período colonial, buscando, principalmente, compreender como essas primeiras representações contribuíram para a formação do sistema literário brasileiro. No segundo capítulo, nos propusemos a analisar os distanciamentos e aproximações do movimento Indianista em relação às produções literárias citadas anteriormente. Para este capítulo sobre o indianismo nos detemos conscientemente a analisarmos a tríade alencariana, O Guarani (1857), Iracema (1865) e Ubirajara (1874) observando como José de Alencar, e outros escritores românticos, lidaram com o passado colonial e a dizimação dos povos indígenas formulando um projeto de nação que elegeu o índio transfigurando-o como elemento constitutivo e representante desta nação. Além de compreender como essa representação está ligada à uma tradição literária.

Em seguida, no capítulo 3, a partir da análise da trajetória de Antonio Callado procuramos compreender como este escritor se apresenta como sucessor de uma literatura empenhada que busca dar conta do país através da escrita, e, que, ao elencar o índio para sua produção literária, passa a pertencer a uma tradição. Para mais, nos desafiamos a compreender o dilema artístico de pertencer a essa tradição e de atualizá-la segunda as exigências contemporâneas.

Por fim, no capítulo 4, tendo como base o que já foi trabalhado nos capítulos anteriores, analisaremos Quarup como herdeiro de uma tradição literária empenhada. Para 
isso, elencaremos elementos na narrativa que revelem a relação entre fato estético e fato histórico buscando compreender a razão pela qual os elementos indianistas ainda estão presentes no romance, ainda que se distancie e supere o indianismo em vários momentos.

O apanhado histórico da presença do índio que construímos neste trabalho serve como suporte, a partir da perspectiva que relaciona o fato estético com o fato histórico, para sustentar a tese de que esses diferentes momentos articulam diferentes representações dos indígenas que sintetizam a dinâmica da história brasileira. Tomaremos como pressuposto, dessa forma, que a literarização do elemento indígena teve sempre uma função social e política na literatura, além de que a transfiguração do indígena surge no texto literário como uma mediação estética que possibilita a formação de uma consciência acerca da história como um todo e não como partes ou momentos desarticulados entre si. Dessa forma, temos como base o princípio estruturante de Antonio Candido (2006a, p. 16) que considera a estrutura histórica do país como "componente da estruturação da obra", elaborando uma crítica que torna intrínsecos à obra elementos que antes eram considerados periféricos como, por exemplo, a história e a sociologia.

Nos primeiros contatos dos índios com os portugueses, é provável que não tenha havido temor ou qualquer presságio do que se tratava e nem premonição do que estava por vir, tendo em vista que vários são os registros de como facilmente os índios entravam e exploravam as naus. Certo deve ter sido o espanto dos índios ao verem aqueles homens que chegavam sobre o mar. Não era possível diante do mundo em que viviam prever a futura dizimação dos seus valores, costumes e credos. Neste sentido, Darcy Ribeiro avalia assim a dimensão desse contato:

Esse conflito se dá em todos os níveis, predominantemente no biótico, como uma guerra bacteriológica travada pelas pestes que o branco trazia no corpo e eram mortais para as populações indenes. No ecológico, pela disputa do território, de suas matas e riquezas para outros usos. No econômico e social, pela escravização do índio, pela mercantilização das relações de produção, que articulou os novos mundos ao velho mundo europeu como provedores de gêneros exóticos, cativos e ouros. (RIBEIRO, 1995, p. 32)

A partir daquele momento, não era mais possível manter ou mesmo reconstituir seu ethos. Para que os índios se tornassem "civilizados", do ponto de vista europeu, era necessário que houvesse um esvaziamento de tudo que os diferenciassem e, portanto, de tudo - credo, cultura e costumes - que compunha a identidade dos índios. Esse processo de 
anulação da identidade autóctone se deu em primeira estância, pela catequese jesuítica que se apresentou de forma confusa, vertiginosa diante dos credos dos índios, já que estabelecia uma relação entre o bem e o mal baseada em um conceito distante e até mesmo incompreensível sobre o pecado para os índios. O fato é que dentro da cultura indígena esses conceitos e dogmas católicos não encontravam equivalentes, muitas vezes não havia equivalência nem mesmo para nomeá-los na língua dos aborígenes. Aos que se recusavam aceitar esse caminho sem escolhas, já que de um lado estava a completa negação de tudo o que os configuravam como índio e por outro a morte, só lhes restava sair da costa adentrando como podiam, levando as doenças adquiridas pelo contato com o europeu e a desilusão com o retorno do que um dia foram. Mais tarde nem mesmo essa opção desesperada lhe seria possível, pois viriam os Bandeirantes.

Quando aportaram em nosso litoral os portugueses encontraram índios principalmente do tronco Tupi que somavam, aproximadamente, 1 milhão ${ }^{1}$ de nativos divididos em inúmeros grupos locais, que foram denominados mais tarde pelos cronistas europeus de "aldeia". É preciso ressaltar que esse número aproximado não é pouco se considerarmos que a população portuguesa na época teria praticamente o mesmo tamanho.

Os índios que viviam por aqui distribuídos em seus grupos locais possuíam organização social, crenças e rituais, além de estarem submetidos aos conselhos e reuniões de seus chefes. Organizavam-se em malocas, entre quatro e sete por grupo local que, segundo Florestan Fernandes (1948), reuniam de 650, 750 ou 850 indivíduos por maloca ligados por laços sanguíneos. Dentro das malocas realizavam seus rituais, sacrifícios e festas, o que nos leva a afirmar que sua vida social acontecia dentro delas. Florestan tenta descrevê-las no trecho a seguir,

levantam em torno delas (as malocas) uma estacada de troncos de palmeira rachados. Este cerca, de mais ou menos braça e meia de altura, fazem na tão cerrada, que nenhuma flecha pode atravessá-la. Porém, aí tem pequenos buracos pelos quais atiram. Em torno desta estacada erigem ainda outra cerca, uma palissada de paus grossos e compridos, não os colocando, entretanto, junto um do outro, mas a uma distância pela qual não pode passar um homem. (FERNANDES, 1948, P. 61)

Tanto os índios tupis quanto os tapuias, como designaram os portugueses os índios inimigos dos tupis, viviam em guerra frequente devido à necessidade de um território que garantisse lavoura, pesca e caça. Mesmo tendo algum domínio sobre a agricultura, entre

\footnotetext{
${ }^{1}$ Informação disponível em: < http://lusotopia.no.sapo.pt/indexPTPopulacao.html > Acesso em: 12 de maio de 2015.
} 
legumes, raízes e frutas, e tendo como vantagem o consumo da mandioca que se mantinha viva por muito tempo debaixo da terra sem precisar ser colhida e estocada, os índios necessitavam da caça e da pesca que exigia territórios adequados para que fossem praticadas.

A situação de guerrilha que viviam os índios, inclusive dentro do mesmo grupo social, acontecia quando o número de indivíduos dentro das malocas crescia demais e resultava na separação em novas entidades autônomas e hostis. No entanto, essas separações enfraqueciam os índios diante de um inimigo muito menor, porém mais organizado, o homem branco europeu.

Diante desse cenário os portugueses que chegam em naus desembarcam nessas terras embebidos em um desejo empreendedor por comércio sem, inicialmente, nenhuma intenção de povoamento e determinados a submeter os aborígenes que aqui viviam ao que fosse preciso para que atingissem seus objetivos . Para isso, tentaram fazer dos índios aliados de forma pacífica, tentaram submetê-los pela religião, dominaram a costa, avançaram para o interior do país e chegaram à quase total dizimação dos indígenas em um genocídio feroz.

Todos os registros disponíveis sobre a população indígena durante o período colonial são de homens formados em Portugal ou em outros países da Europa e se configuram como relatos de viagens ou como textos que se submetiam às necessidades da Igreja. Eram, portanto, escritos designados ao consumo luso ou europeu.

Neste trabalho consideraremos a distinção feita por Antonio Candido em "Literatura como sistema", do livro Formação da Literatura Brasileira entre manifestações literárias e literatura. Candido afirma que esta para que exista como "aspecto orgânico da civilização" é preciso que entre suas características internas estejam elementos "de natureza social e psíquica que se manifestam historicamente" (CANDIDO, 2009, p.25), além de um conjunto entre produtores literários, receptores formando diferentes públicos e um mecanismo transmissor, no caso, a linguagem. Somente como resultado desse somatório é possível que a literatura apareça “como sistema simbólico, por meio do qual as veleidades mais profundas do indivíduo se transformam em elementos de contacto entre os homens, e de interpretação das diferentes esferas da realidade" (CANDIDO, 2009, p.25).

Neste ponto, interessa-nos saber que para Candido as produções feitas no século XVI são manifestações literárias. Sua justificativa é a de que "em fases iniciais, é frequente não encontrarmos esta organização, dada a imaturidade do meio, que dificulta a formação de 
grupos, a elaboração de uma linguagem própria e o interesse pelas obras" (CANDIDO, 2009, p.25). Mesmo reconhecendo a importância e qualidade de textos como os de Anchieta, Antonio Vieira e Gregório de Matos, Candido esclarece que a formação de um sistema se liga, e só se torna possível, quando ocorre uma "continuidade ininterrupta de obras e autores, cientes quase sempre de integrarem um processo de formação literária” (CANDIDO, 2009, p.25), o que só acontece, de fato, em meados do século XVIII e se torna concreto no século XIX.

Para Candido (2009, p. 28), o sistema literário brasileiro se configura de forma efetiva quando há um público leitor, um conjunto de autores reunidos em torno dos mesmos interesses - assim, consideravam "a atividade literária como parte do esforço de construção do país livre" - além de, uma produção sistemática de obras literárias de maneira a construir uma tradição.

No século XVI e XVII o que tínhamos em termos de manifestações literárias eram, em sua maioria, produções ligadas à Igreja e à catequese. Nesse momento, presenciava-se o período Barroco o que representava para os escritores um terreno fértil para disseminação de sua ideologia se valendo do artifício da religião como doutrina na catequização dos índios. Essa catequização por meio das produções literárias relacionava de forma arbitrária os ritos e costumes dos nativos ao mal, enquanto que às diretrizes lusocatólicas eram associadas ao bem.

Como referencial teórico para justificarmos a tradição crítica brasileira que trata do problema da formação da literatura relacionando-a com a formação nacional utilizaremos os textos de Antonio Candido: o livro Formação da literatura brasileira, os ensaios "Literatura e Subdesenvolvimento", "A nova narrativa", além de "Letras e ideias no período colonial", "Estrutura literária e função histórica" e "Crítica e Sociologia".

Após essa construção temporal da representação do autóctone, buscamos compreender e investigar, no terceiro capítulo quais foram as influências dos textos jornalísticos de Antonio Callado em suas obras literárias que tratam do elemento indígena, especificamente, Quarup. Para isso, analisamos o livro Esqueleto na Lagoa Verde, além de entrevistas concedidas pelo autor no período entre 1950 e 1959.

Aliado ao material produzido por Callado à teoria de Mikhail Bakhtin (2015) sobre os problemas do autor em Estética da criação verbal, buscamos compreender quais as 
influências e consequências das escolhas de Callado em sua vida jornalística que surgem em seus textos literários.

Como já dito anteriormente, no último capítulo, buscamos nos aprofundar na análise da obra Quarup, procurando compreender esse tipo de representação do elemento indígena que difere consistentemente do que já havia sido feito no período colonial e no Indianismo com os escritores românticos, mas que, no entanto se revela como herdeira de uma tradição. Buscamos compreender a forma segundo a qual os elementos indianistas ainda estão presentes no romance e se Callado foi capaz de elevar sua subjetivação (LUKÁCS, 1970) ao ponto de alcançar uma certa universalização.

Abordaremos, neste último capítulo, como a cerimônia do quarup perpassa toda a narrativa e seus personagens no sentido de revelar transformações e renascimentos, mesmo em um momento histórico de forte pessimismo e sentimento de impotência. Além disso, analisaremos o personagem Nando sob a perspectiva do "idealismo abstrato" e o "herói problemático" de Lukács (2000).

Diante disso acreditamos ser possível um trabalho que, considerando a composição do romance e sua composição com abordagem de temáticas tão diversas, seja capaz de representar de forma potente a realidade ao revelar criticamente nossa incompletude como nação, além da profunda distância ainda não superada e nem resolvida, sob vários aspectos, entre homem branco e índio. 
Quando um indígena passa da condição de índio tribal - em que sua consciência é seu ethos específico - para a condição genérica de "índio civilizado", a antiga consciência começa a ruir e a se decompor para dar lugar a uma forma que permanece sendo étnica, mas já corresponde, como mentalidade, à sua nova condição. [...] Nessas circunstâncias cada um dos corpos ideológicos apresentados ao índio é uma consciência "do outro" que busca minar a consciência do índio em suas bases de sustentação.

Darcy Ribeiro 


\section{CAPÍTULO 1}

\section{OS PRIMEIROS RELATOS E A TRADIÇÃO DA LITERARIZAÇÃO DO ELEMENTO INDÍGENA}

O objetivo deste capítulo é recuperar representações do elemento indígena em textos anteriores ao período Romântico, que é, como se sabe, o marco fundamental do indianismo na literatura brasileira.

Ao pensar o tema, já bastante discutido, do indígena no sistema literário brasileiro, buscam-se elementos que problematizem a sua representação e, consequentemente, a transfiguração do índio como elemento auxiliar na constituição da ideia de nacionalidade brasileira. Contudo, é preciso estar consciente de que a problematização da transfiguração do índio no nosso sistema literário não deve ser analisada como um recorte da nossa história, mas, pelo contrário, deve ser vislumbrada como um elemento que negrita os problemas da formação do país.

Nesta dissertação, buscamos pensar o tema do indígena no sistema literário brasileiro encarando a transfiguração literária como um processo interno ao sistema literário nacional. Neste sentido, os elementos que anteriormente figuravam nas produções literárias cujo tema se aproximavam do índio permanecem recriados de forma renovada em obras posteriores. Nessa perspectiva, buscamos compreender a transfiguração literária como uma condição para a eficácia artística na representação da realidade, já que ao transfigurar a realidade a obra literária deixa de ser mero documento e se torna capaz de revelar o movimento da história em sua totalidade.

Assim, escolho iniciar minha análise a partir da presença dos índios em textos escritos desde os "cronistas", viajantes e religiosos que estiveram por este território que viria a ser o Brasil, entre os séculos XVI e XVII, pelo que consensualmente denominamos "literatura de informação".

Diante desse ponto inaugural devo demonstrar, neste capítulo, como e quais foram as influências desse primeiro contato e as impressões do europeu sobre o índio que, de certa forma, resultaram no movimento elaborado e consciente do indianismo no Romantismo 
do século XIX articulado ao aporte teórico que aborda a origem e a expansão do nacionalismo (ANDERSON, 2012).

Em seguida, analisarei aspectos relevantes para construção do nosso panorama e rastreamento da presença do índio, em um breve panorama ${ }^{2}$, observando as obras de José de Anchieta, Bento Teixeira e Gregório de Matos, além de O Uraguai, de Basílio da Gama e Caramuru, de Santa Rita Durão.

\subsection{Dos cronistas ao Arcadismo: o índio como elemento estético}

Ao optar por analisar e observar os registros dos viajantes, que como dito anteriormente serviam aos interesses metropolitanos, nós rejeitamos a possibilidade de compreender a literatura como entidades distintas e separadas, mas como, algo em processo e que é capaz de captar a dinâmica histórica.

Buscaremos analisar como a representação ficcional literária do índio na literatura brasileira a partir dos registros dos "cronistas" e viajantes diante da exuberância e liberdade comportamental do índio, em relação aos costumes europeus, articularam a representação ficcional literária em textos narrativos. De certo, o registro que os viajantes fizeram em seus relatos e em suas cartas muito tinham do fascínio quase cosmogônico que possuíam esses desbravadores ao chegarem à terras como as da América, como as do Brasil. É a esse fascínio, exatamente, que se refere Sérgio Buarque de Holanda no prefácio de Diários da descoberta da América, de Cristóvão Colombo:

Para numerosos viajantes, o cenário americano estava repleto de misteriosas e inegáveis possibilidades. Ali, o milagre parecia novamente incorporado à natureza: uma natureza ainda cheia de graça matinal, em perfeita harmonia e correspondência com o Criador. (HOLANDA, 1998, p. 1)

Benedict Anderson, no livro Comunidades Imaginadas, no capítulo intitulado "A biografia das nações", afirma que,

\footnotetext{
${ }^{2}$ Tendo conhecimento da amplidão do tema indígena na literatura brasileira procuramos nos deter aos aspectos que fossem importantes para compreender o processo de transfiguração da presença literária do indígena. Para isso, na linha temporal que nos propomos a construir deixamos de fora obras com alto nível de relevância para a literatura brasileira, mas que, de alguma forma, desviariam o objeto de nosso estudo ao considerarmos que tais obras trariam outras problematizações ao trabalho. São elas: Macunaíma, de Mário de Andrade, "Meu tio, o Iauaretê", de Guimarães Rosa, a poesia de Gonçalves Dias, entre outros.
} 
Todas as mudanças profundas de consciência, pela sua própria natureza, trazem consigo amnésias características desses esquecimentos, em circunstâncias históricas específicas, nascem narrativas ${ }^{1}$. (ANDERSON,2012, p.266)

Discorrendo sobre o assunto, Anderson utiliza do exemplo da fotografia como registro de uma lacuna de tempo entre a nossa infância e a vida adulta e tudo mais que se apaga nesse trajeto, afirmando que por não lembrarmos dessa fase infantil precisamos que ela seja narrada. Diante disso, álbuns de fotografia, certidões de nascimento e diários tornam legítimas nossa concepção de identidade. Ao pesquisar a literatura de informação, as crônicas dos viajantes e os textos dos jesuítas, que são o recorte escolhido aqui para representar a presença do índio no período anterior ao Romantismo, nos propomos a reconstruir essa linha apagada na nossa memória para compreendermos por onde passa nossa construção literária e nossa nacionalidade. E, principalmente, perceber um possível liame do sistema literário entre o que é pré-romântico e o que é pós-romântico no que se refere à transfiguração do índio.

Certamente, todo e qualquer rastreamento da presença do indígena nesses textos deve levar em consideração que se trata do colonizador europeu nos dizendo como eram os aborígenes, como viviam e o que aconteceu. Portanto, o enfoque é unilateral, trata-se do índio como objeto do discurso do dominador. Ainda assim é possível perceber que essa imagem relatada pelo homem europeu ou seu descendente não é homogênea para os autores, já que parece não haver, mesmo para os romancistas, uma concordância em relação à constituição do personagem indígena. Como explica Alcmeno Bastos em $O$ índio antes do indianismo,

Até entre os românticos há diferenças notáveis. José de Alencar não aceitou as virgens índias de Gonçalves de Magalhães por que lhes pareceram inautênticas, desprovidas de "cor local" identificadora de sua americanidade. Por outro lado, a cordialização do confronto indígena x colonizador europeu processada na sua ficção contrapõe-se a antagonismo manifesto entre brancos e índios observável na poesia de Gonçalves Dias. Dicotomia equivalente - não necessariamente semelhante, porém - é observável entre os índios de Basílio da Gama e Santa Rita Durão, especialmente na sua relação com os representantes da fé cristã: os padres jesuítas e o náufrago português Diogo Álvares Correia, o Caramuru." (BASTOS, 2011, p. 20.)

A literarização do elemento indígena está diretamente ligada à representação que a sociedade faz do indígena, bem como os objetivos dessa representação e o intuito de legitimação do discurso conferido a ela, que mudam em cada recorte de tempo e que ainda no mesmo recorte podem se demonstrar heterogêneo.

Contudo, algumas descrições físicas e comportamentais da impressão dos cronistas e viajantes e até mesmo dos jesuítas parecem servir de construção coerente ao índio 
do Romantismo. Todos os cronistas que se detiveram a escrever sobre aparência do índio exaltaram a força, a beleza, a cor e, obviamente, a naturalidade com que viviam com a nudez, além de um possível senso estético ligado aos adornos e pinturas que os índios faziam em si, como descreve a carta de Pero Vaz de Caminha, escrita em 1500:

A feição deles é serem pardos, maneira de avermelhados, de bons rostos e bons narizes, bem feitos. Andam nus, sem nenhuma cobertura. Nem estimam de cobrir e mostrar suas vergonhas; e nisso tem tanta inocência como em mostrar o rosto. Ambos traziam os beiços de baixo furados e metidos neles seus ossos brancos e verdadeiros, do comprimento de uma mão travessa, e da grossura de um fuso de algodão, agudo na ponta como um furador. Metem-nos pela parte de dentro do lábio, e a parte que fica entre o lábio e os dentes é feita á roque de xadrez, ali encaixado de maneira a não prejudicar o falar, o comer e o beber. (CASTRO, 2014, p.90)

De modo semelhante, Jean Lery ${ }^{3}$, que viveu no Brasil durante o ano de 1557 juntamente com Nicolau de Villegagnon na empreitada francesa pelas Américas, afirma que,

Os selvagens do Brasil, habitantes da América, chamado Tupinambás, entre os quais residi durante quase um ano e com os quais tratei familiarmente, não são mais maiores nem mais gordos do que os europeus; são porém mais fortes, mais robustos, mais entroncados, mais bem dispostos e menos sujeitos a moléstia. (LERY, 1980, p. 111)

Sempre presentes nesses relatos de viajantes e jesuítas estão o vigor físico e as habilidades para caça, pesca e toda coragem e desenvoltura nas lutas em combate, como diz Anchieta que "são guerreiros e grande frecheiros; basta ver um olho só descoberto a um homem para lhe pegar; [e] são tão destros que não lhe escapa passarinho que não matem, e a frechadas matam o peixe na água" (ANCHIETA, 1988, p. 441-442). Mesma opinião de Jean Lery:

Já disse a que ponto os indígenas manejam destramente os seus tacapes; quanto ao arco dirão comigo os que os viram em exercício que, embora nus e sem braçal, o envergam com tanta envoltura e atiram com tanta rapidez que não desagradariam aos ingleses, considerados ótimos flecheiros, pois um índio, com molhos de flechas na mão lançaria uma dúzia de setas mais depressa do que um inglês meia dúzia delas. (LERY,1980, p. 147-148)

Contudo, há também outras fontes históricas europeias que influenciaram nossos escritos, a saber, a visão do selvagem pacífico que vive em lugares paradisíacos sob suas próprias regras também pode ter sido fonte de Thomas Morus em Utopia (1516), de Voltaire

\footnotetext{
${ }^{3}$ Jean de Léry (1534-1613) esteve no Brasil na mesma época em que Nicolau Durand de Villegaignon tentou desenvolver o projeto de estabelecer no Rio de Janeiro a 'França Antártica', uma colônia que serviria à exploração mercantil e abrigaria os protestantes perseguidos na França. No livro Viagem à Terra do Brasil (1557), Jean de Léry documentou a incompreensão do nativo em relação à necessidade de acumulação de bens por parte dos colonizadores.
} 
ao descrever o Eldorado de Candide (1759). Vigor físico, disposição, valentia, coragem e precisão na caça e pesca surgem como elementos importantíssimos na construção do índio mitificado de José de Alencar, por exemplo, e de outros escritores.

Assim, consideramos que a transfiguração do indígena inicia-se a partir desses primeiros relatos dos europeus sobre a Terra do Brasil. Dessa forma, podemos considerar que esses cronistas foram os primeiros a de alguma forma esboçar em suas narrativas o processo de transfiguração do indígena. Compreender a motivação e intenção dos cronistas/viajantes considerando Pero Vaz de Caminha, Hans Staden, Pedro Álvares Cabral, Jean Lery, Henry koster, André Thevet, entre outros - é, de certa forma, sob essa perspectiva compreender um elemento importante da transfiguração do índio na literatura brasileira.

De certo, a visão dos primeiros cronistas e viajantes esboçou a base para uma tradição da literarização do indígena que de forma progressiva foi se tornando cada vez mais presente nas produções seguintes e na expressão das contradições históricas e estéticas com que os escritores brasileiros precisavam lidar. Mesmo a visão deformada ideologicamente dos primeiros cronistas permaneceu nas produções posteriores, contudo, devido tanto ao atraso quanto pelo desejo de elevação da vida da colônia agregavam novos aspectos às obras literárias. Como esclarece Antonio Candido (2009, p.28),

Os escritores neoclássicos são quase todos animados do desejo de construir uma literatura como prova de que os brasileiros eram tão capazes quanto os europeus; mesmo quando procuram exprimir uma realidade puramente individual, segundo os moldes universalistas do momento, estão visando este aspecto. É expressivo o fato de que mesmo os residentes em Portugal, incorporados à sua vida, timbravam em qualificar-se como brasileiros, sendo que os mais voltados para temas e sentimentos nossos foram, justamente, os que mais viveram lá, como Durão, Basílio ou Caldas Barbosa.

Esses textos não ficcionais revelam-se como contribuição para pelo menos dois livros de Alencar, Iracema (1865) e Ubirajara (1874), como podemos observar nas notas longuíssimas de esclarecimento e nas citações às fontes documentais como as crônicas dos viajantes. O prefácio de Ubirajara, que o autor nomeia como Advertência, revela uma mostra do que buscamos explicitar. Neste Alencar (1999, p.15) chega a pedir que o leitor não se impressione com suas “apreciações muitas vezes ridículas”, já que elas, segundo o autor, são necessárias para dar ideia exata dos costumes e caráter dos índios. Em Iracema também estão presentes exageradas explicações, notas e epílogos. Além disso, o autor romântico chega a alertar ao leitor, 
Quem por desfastio percorrer estas páginas, se não tiver estudado com alma brasileira o berço de nossa nacionalidade, há de estranhar em outras coisas a magnanimidade que ressumbra no drama selvagem a formar-lhe o vigoroso relevo (ALENCAR, 1998b, p.13)

Tal afirmação do autor nos revela um aspecto ainda mais complexo de nossa análise, a questão da sobreposição do conquistador à própria idealização do indígena. Como se fossemos capazes de contornar e compreender a relação colonizador/índio se olhássemos com "alma brasileira", como se a partir desse olhar fosse possível que o índio, inventado, transfigurado e poetizado conseguisse substituir, nos fazendo esquecer ou minimizar, a quase dizimação dos índios, sua escravidão e as violências sofridas neste processo.

Nos textos literários essas referências às informações histórico-etnográficas são utilizadas pelos autores como mais um mecanismo para, de alguma forma, tentar trazer veracidade para o texto literário. De fato, no que concerne aos romancistas indianistas, sabíamos que estavam empenhados em um projeto estético-ideológico que trataria de destacar o índio e a natureza exuberante como elementos dessa construção de nacionalidade que deveria, necessariamente, resgatar em um passado relativamente distante, cor local, exotismo, além da evocação de civilizações longínquas e de sociedades diferentes ou desaparecidas e sentimentos não individuais, mas partilhados pela comunidade e representativos das informações históricas que sustentassem esse projeto e esse sentimento de desejo de nação. É dessa forma que o aporte da literatura de informação escrita por viajantes e jesuítas é utilizada como a fotografia a que se refere Anderson, e a quem já mencionamos anteriormente, na tentativa de propositalmente nos fazer lembrar do que em nossa essência sempre fomos ou no que, genuinamente, temos como herança do índio.

No entanto, se por um lado os apelos e retomadas às cartas e aos relatos de viajantes eram utilizados pelos românticos como suporte que fosse capaz de trazer veracidade a esse índio esteticamente transfigurado, por outro, esses mesmos escritores precisavam se valer das notas, prefácios e de outros textos auxiliares para justificar como os índios eram vistos e tratados como bárbaros, como podemos observar Alencar no prefácio de Ubirajara, em que o autor posiciona-se de forma a defender o caráter humanizado do indígena,

Releva ainda notar que duas classes de homens forneciam informações acerca dos indígenas: a dos missionários e a dos aventureiros. Em luta uma com outra, ambas se achavam de acordo nesse ponto, de figurarem os selvagens como feras humanas. Os missionários encareciam assim a importância da sua catequese: os aventureiros buscavam justificar-se da crueldade com que tratavam os índios. Faço estas advertências para que ao lerem as palavras textuais dos cronistas citados nas notas seguintes não se 
deixem impressionar por suas apreciações muitas vezes ridículas. (ALENCAR, 1999, p. 14)

Não podemos nos esquecer de que a visibilidade dada aos índios através dos inúmeros textos de cronistas e jesuítas eram produzidas a partir das vertentes do colonizador, que, certamente, eram embebidas da ideologia predominante na Europa, que por sua vez acreditava que o índio era um bárbaro que deveria ser catequisado e domesticado. Entre a literatura de informação e os romances indianistas do romantismo, o índio foi descrito e representado das mais diferentes e diversas formas, desde a exaltação e valorização da bravura e características diretamente ligadas à fauna e a flora, até mesmo a demonização dos rituais com os mortos, a antropofagia ou o total descarte que davam aos bebês que nasciam com alguma deficiência que eram vistos “como sintomas de barbárie” (BOSI, 1992, p. 73).

Pela ótica do colonizador, se os índios eram bárbaros precisavam ser domesticados, por não terem a mesma fé precisavam ser catequisados. E é com os jesuítas, principalmente Anchieta, que podemos perceber a existência de uma polarização em suas principais linhas de produção literária sobre os índios. Primeiramente, temos os poemas escritos em tupi que revelavam um índio dócil, admirável e receptivo ao credo católico; e então, do outro lado, surgia o índio bárbaro, antropófago e disponível espiritualmente para conversão, já que para o colonizador os indígenas não possuíam qualquer concepção religiosa.

Para os jesuítas, e dessa forma também para José de Anchieta, a catequese dos nativos se tornou uma obsessão, algo que, de certo, já estava presente na carta de Carta de Caminha $^{4}$, escrita em 1500:

\begin{abstract}
parece-me gente de tal inocência que, se nós entendêssemos a sua fala e eles a nossa, seriam logo cristãos, visto que não entendem crença alguma, segundo as aparências. E, portanto, se os degredados que aqui hão de ficar aprenderem bem a sua fala e os entenderem, não duvido que eles, segundo a santa tenção de Vossa Alteza, se farão cristãos e hão de crer na nossa santa fé, à qual praza o Nosso Senhor que os traga porque certamente esta gente é boa e de bela simplicidade. E imprimir-se-à facilmente neles todo e qualquer cunho que quiserem dar, uma vez que Nosso Senhor lhes deu bons corpos e bons rostos, como a homens bons. E portanto Vossa Alteza, que tanto deseja acrescentar a santa fé católica, deve cuidar da salvação deles. E aprazerá a Deus que com pouco trabalho seja assim. (CASTRO, 2014, p.108-109)
\end{abstract}

Contudo, a catequese que servia convenientemente aos interesses europeus não aconteceu de forma pacífica, se, inicialmente, não existiram agressões físicas, certamente, esteve presente a violência impositiva contra a cultura e costumes indígenas, além da total

\footnotetext{
${ }^{4}$ Neste trabalho, utilizamos trechos da Carta de Caminha retirados do livro A carta de Pero Vaz de Caminha, de Silvio Castro - Porto Alegre: L\&PM, 2014
} 
anulação do espírito autóctone. Se anteriormente dividimos a produção de Anchieta em dois polos, o trecho abaixo se refere à escrita do padre em que é notório um total repúdio e estranheza à cultura indígena,

Estes entre os quais vivemos estão espalhados 300 milhas (segundo nos parece) pelo sertão; todos eles se alimentam de carne humanas e andam nus; moram em casas feitas de madeira e barro; cobertas de palhas ou com cortiças de árvores; não são sujeitos a nenhum rei ou capitão, só tem em alguma conta os que alguma façanha fizeram, digna do homem valente, e por isso comumente recalcitram, porque não há quem os obrigue a obedecer; os filhos dão obediência aos pais quando lhes parece; finalmente, cada um é rei em sua casa e vive como quer; pelo que nenhum ou certamente muito pouco fruto se pode colher deles, se a força e o auxílio do braço secular não acudirem para domá-los e submetê-los ao jugo da obediência. (ANCHIETA, 1988, p. 55)

Era de se esperar que um padre jesuíta destinado a "salvar" bárbaros que, em seu entendimento necessitavam da fé cristã, um pouco mais de cuidado diante da cultura nativa. Aliado ao seu espanto diante da cultura autóctone, Anchieta se valia do formato literário do auto medieval, poemas e sermões que se estruturavam nas oposições mal e bem, céu e inferno, anjo e diabo. No entanto, aqui o que nos interessa como análise, é o fato de que, as escolhas feitas pelo padre no que diz respeito à construção do mal e do inferno transpunham para o tupi, conforme Bosi (1992), a mensagem católica adentrando ao imaginário indígena, em correlações que nem sempre eram apropriadas e que devido a isso se esvaziavam de sentido para o nativo. Como exemplo dessa inadequação podemos observar a relação TupãDeus. Para o índio Tupã era o nome dado a uma força cósmica que eles identificavam no trovão, enquanto que Deus para os católicos, segundo o Novo Testamento da Bíblia, como sabemos, se trata de um ser uno, onipotente, no entanto, também trino e filho de mortais, no caso, José e Maria.

Em termos de religião, os costumes indígenas eram vistos pelos europeus como diabólicos, primeiro devido ao canibalismo e adoração aos elementos da natureza, e segundo porque as convicções cristãs na Idade Média classificavam assim as comunidades "pagãs".

Imbuído dessas certezas Anchieta desenvolve textos como $\mathrm{Na}$ Aldeia de Guaraparim $^{5}$, escrito em 1585, que tem como temática central quatro diabos que são denominados com nomes indígenas e que tentam dominar a aldeia contra a força do bem, identificada como Anjo. O pecado e as ações diabólicas são apontados nos textos como algo

\footnotetext{
${ }^{5}$ ANCHIETA, José S. J. (1954) Poesias. Manuscrito do século XVI, em português, castelhano, latim e tupi. Tradução de Maria de Lourdes de Paula Martins. São Paulo: Comissão do IV Centenário.
} 
sempre ligado a costumes ou "vícios" dos índios como, por exemplo, a antropofagia, a bebida, o fumo e a poligamia. O Diabo se apresenta nos poemas de Anchieta como a representação perniciosa dos costumes indígenas, de acordo com a visão europeia. Como no trecho, "- Sou Guairaxá, o bêbado, Grande boicininga, jaguar, Antropófago, agressor, Andira-guaçu, que voa, Demônio assassino “(ANCHIETA, 1989, p.701), o que podemos observar é que para o jesuíta a cultura indígena estava em uma posição inferior e reprovável diante dos preceitos cristãos.

Temos na obra de Anchieta a presença do índio, contudo, não há vestígios de indianismo, já que para o autor o índio e sua condição cultural e de fé estavam em uma situação inferior em relação ao colonizador, assim como para os escritores contemporâneos a ele. Ao mesclar o teatro ibérico, dogma católico e rituais indígenas, Anchieta militava na visão missionária da igreja católica provocando a aculturação dos índios e sua conversão religiosa.

Florestan Fernandes chega a afirmar em sua tese, Organização Social dos Tupinambás (1948) que,

Os portugueses esforçaram-se por obter pacificamente a submissão dos Tupinambá ${ }^{6}$; a missão de Nóbrega e Anchieta foi feita com este objetivo. Contudo, os missionários só conseguiram capturar a simpatia dos Tupinambá de Iperoig. Os demais prepararam-se para a guerra, atacando os portugueses com maior violência ainda [...] Em quinze anos, de 1560 a 1575, os portugueses conseguiram conquistar a terra, expulsar os franceses da região e impor o seu domínio aos aborígenes. (FERNANDES, 1948, p.2728)

Alguns índios conseguiam fugir, outros se submetiam e milhares eram mortos até que os portugueses atingissem o objetivo de retirá-los da costa. Como nos diz Florestan Fernandes a respeito dos Tupinambás instalados em Cabo Frio,

a maioria dos sobreviventes emigrou para o sertão. Alguns dos sobreviventes que fugiram para o sertão constituíram um novo grupal, com o nome de Ararapes. Alguns, entretanto, se submeteram e tornaram-se cristãos. (FERNANDES, 1948, p.30)

O fato é que, por mais que os jesuítas estivessem em um primeiro momento intencionados em submeter o índio de forma pacífica - o que também nos parece contraditório

\footnotetext{
${ }^{6}$ Florestan explica que "o termo Tupinambá é empregado nesta monografia para designar o conjunto de grupos tribais descritos sob este nome nas fontes compulsadas. Assim, estão compreendidos nestes estudos os grupos tribais Tupi que, na época da colonização do Brasil, entraram em contacto com os brancos no Rio de Janeiro e na Bahia; e os grupos tribais Tupis que, depois, povoaram o Maranhão, o Pará e a Ilha dos Tupinambarana." (FERNANDES, 1948,p.16)
} 
e impossível já que esta "submissão pacífica" somente se daria diante do esvaziamento de credo e fé por parte dos índios - eles estavam intrinsecamente envolvidos neste processo violento de colonização. Certamente, os rituais praticados pelos indígenas - como, por exemplo, os de iniciação, de nascimento, de renomação e funerários, além do sacrifício ritual - eram impossíveis de serem aceitos pelo homem branco, europeu e católico. Costumes próprios da cultura indígena que possuíam extrema importância na vida social das aldeias como o rito de iniciação das mulheres. Florestan Fernandes relata tal rito com base nos escritos de Thevet $^{7}$, e revela que as meninas eram iniciadas quando aparecia o primeiro fluxo menstrual que se chamava nhemõdigara, em que,

as raparigas, quando chega o tempo da menstruação, elas deitam imediatamente, nas suas redes as envolvem e costuram realmente como fariam com um defunto em sua mortalha e deixam unicamente de costurar para o lado da boca para que elas possam respirar. (FERNANDES, 1948, p. 228)

Fernandes (1948) explica que o rito referia-se à morte e renascimento e que dentro do grupo local tinha importância vital, pois fazia com que essa menina se tornasse mulher, o que implicava que agora ela estaria pronta para assumir as tarefas destinadas às mulheres e, além disso, "podiam entreter aventuras amorosas e contrair matrimônio" (FERNANDES, 1948, p.229).

Seguindo a linha temporal da presença do índio como protagonista nas produções literárias, temos em um segundo momento do período da colonização a obra de Bento Teixeira, Prosopopeia (1601). Nesta obra observamos observar com grande exaltação, assim como algumas obras de Anchieta, aos feitos do colonizador luso, em seu caso, mais especificamente, das ações e triunfos de Duarte Coelho Pereira, primeiro donatário da Capitania do Pernambuco e que era pai do herói do poema, Jorge de Albuquerque Coelho. O sucesso das capitanias se dava pelo princípio de que com uma costa da extensão da qui tínhamos era preciso "aplicar à medida do possível o método predileto dos colonos portugueses dividir para reinar" (FERNANDES, 1948, p.29).

Contudo, há dois aspectos relevantes e que diferenciam a Prosopopeia da obra de Anchieta. Primeiramente, a presença mínima do índio e o abandono à perspectiva religiosa. Durante todo o poema só há referência ao índio como "bárbaro", "bárbaros cruéis", "Bárbaro

\footnotetext{
${ }^{7}$ Frei André Thevet era franciscano, explorador, escritor e cosmógrafo da expedição do calvinista Nicolas Durand de Villegaignon. Thevet esteve no Brasil nos anos de 1555 e 1556 e escreveu sobre os costumes dos índios.
} 
difuso e roto", etc. Ao analisarmos a retomada sempre constante do bárbaro como definição do índio no poema épico de Bento Teixeira o que percebemos é o desprezo e depreciação do índio, além da despersonalização do nativo, já que não há subjetivação na representação do índio, o que somente acontecia com os heróis. Estes eram nomeados, louvados, individualizados. Ao se recusar a associar o índio à terra em que vive, buscando seu aspecto de "nacionalidade", o autor da Prosopopeia faz com que, na obra, o colono negue o direito do nativo a terra e que, assim, por sua vez, acaba lhe negado o direito de ser índio.

O fato é que, este momento é uma outra etapa da colonização o que resulta em uma representação diferenciada da anterior. Se antes o índio era um elemento carente de catequização e conversão, no século XVII o cenário é do "Brasil que se desdobra como um portento de glórias nos três reinos da natureza, enquadrando a glória do homem, - que converte o gentio, expulsa o herege e recebe como salário as dádivas vegetais e minerais, a cana e o ouro" (CANDIDO, 2006a, p.103).

Nesse sentido, a transfiguração do indígena está a serviço dos escritores barrocos como instrumento de doutrina. Candido (2006a, p.103) afirma que,

Não suprimindo, mas envolvendo e completando o conhecimento objetivo da realidade, a visão ideológica e estética da colônia se fixa de preferência na apoteose da realidade e no destino do europeu, do pecador resgatado pela conquista e premiado com os bens da terra, quando não redimido pela morte justa.

Essa visão transfigurada se integrou de forma permanente à nossa literatura e mesmo a nossa educação, como afirma Candido (2006a), configurando nossa visão teológica sobre as coisas e sobre a existência, além do drama interno entre a carne e o espírito.

A negação ao ser índio, elaborada por Bento Teixeira e outros autores barrocos, envolve inúmeros aspectos sociais da vida dos índios, já que o aborígene que vivia por aqui estava diretamente ligado a ela. A escolha do território para fixação do grupo local era um problema de dimensão vital. Isto porque para os indígenas esta terra deveria proporcionar acesso fácil e seguro às fontes de subsistência necessárias. Eram consideradas as proximidades com terras que fossem agrícolas e férteis, além de rios ou mesmo da costa marinha. Estavam os índios, como já sabemos, diretamente ligados à terra e à natureza, contavam o tempo através das lunações e esperavam ansiosamente pela chuva. Todas essas práticas só confirmam a sua estreita dependência dos ciclos do mundo natural. Portanto, quando Bento Teixeira, ou qualquer outro poeta, nega a relação entre indígena e terra, ele o faz em uma dimensão ainda maior que a de proprietário dela, ele nega ao índio seu direito de 
ser aborígene, de ter seus hábitos, sua cultura, suas práticas sociais, ele lhe nega o direito de existir.

Como explicitamente podemos ver no trecho abaixo do poema,

O Princípio de sua Primavera,

Gastarão seu destricto dilatando,

Os bárbaros cruéis e gente Austera,

Com meio singular, domesticando.

E primeiro que a espada lisa e fera.

Arranquem, com mil meios d'amor brando,

Pretenderão tirá-la de seu êrro,

E senão porão tudo a fogo e ferro. (TEIXEIRA, 1601, p. 39)

O trecho destacado de Prosopopeia (1601) se refere às ações dos heróis Jorge de Albuquerque e Duarte Coelho contra os índios no processo de ampliação da capitania, caso isso não acontecesse de forma pacífica. É a confirmação da total aniquilação do indígena, caso não se integrasse aos desejos do colonizador.

Se nos textos de Anchieta a religião serviria como escape e objeto de conversão para o índio perdido em relação aos preceitos católicos, em Bento Teixeira a "correção" vem sempre acompanhada do pronto braço forte do colonizador, "Pretenderão tirá-la de seu êrro, / E senão porão tudo a fogo e ferro", ou seja, se necessário fosse não hesitariam em usar a força contra os índios. É com esse índio caracterizado como bárbaro, que atrapalhava os objetivos de expansão do colonizador que a figura do índio estreia na literatura brasileira - isso ao considerarmos Prosopopeia como a primeira obra literária produzida na colônia - um índio bem diferente do descrito pelos viajantes que primeiro estiveram por aqui e que pudemos observar no início desse capítulo.

Esta narração do período colonial e, portanto, do início da formação do que seríamos como nação é incompleta porque se apresenta como uma memória selecionada de alguém. Inicialmente, do colonizador e seu lugar de explorador, em seguida, de jesuítas que se posicionavam politicamente em sua obsessão de catequese e aculturação diante dos índios. É por ser construída a partir de aspectos selecionados, já que se trata de autores brancos, colonizadores ou filhos dele, com boa escolarização ou que dominavam além do português o 
tupi, que a literatura foi, no caso desse rastreamento do índio que nos dispomos a fazer, capaz de capturar contradições e dilemas que, somente, através da arte se tornaram perceptíveis. Como esclarece Octavio Ianni em Nação e Narração:

A literatura é até mesmo uma forma sofisticada de conhecimento, no sentido de compreensão e esclarecimento, ainda que difusa e inconsciente. Surpreende o momento, a situação, o impasse, a tensão, e a realização ou a frustração. Pode revelar o real e o virtual, antes que contemporâneos se deem conta do que vai pelo mundo; prefigurando ações e sentimentos, subjetividades e entendimentos, probabilidades do ser e do devir. (IANNI, 1999, p. 79)

Gregório de Matos, assim como Bento Teixeira, não tem em suas produções literárias o índio como preocupação. Pelo contrário, na obra de "O Boca do inferno", como fora apelidado o poeta baiano, o aborígene surge, apenas, para lembrar de forma sádica e irônica para nobreza baiana o seu passado mestiço, entre branco e índios, resultando nos Caramurus. Como podemos observar no primeiro quarteto do soneto, "Aos principais da Bahia chamados os Caramurus", para Gregório a descendência mestiça era motivo de desprezo:

Há cousa como ver um Paiaiá

Mui prezado de ser Caramuru,

Descendente do sangue de Tatu,

Cujo torpe idioma é o cobé pá. (MATOS, 1990, p.640)

Nos sonetos de Gregório de Matos, especificamente, “Aos principais da Bahia chamados os Caramurus", "A Cosme Moura Rolim insigne mordaz contra os filhos de Portugal" e "Ao mesmo assunto" (MATOS, 1976, p. 108, 109), o que se torna aparente é a inserção do léxico tupi como artefato provocador da estranheza pelo fator linguístico empregado da poesia, além de em percepções mais complexas a desqualificação da cultura indígena que é articulada nos poemas como inferior. Em, "Ao mesmo assunto", temos por duas vertentes a inferiorizarão do indígena: primeiramente, pela aparência física:

Um calção de pindoba à meia zorra

Camisa de urucu, mantéu de arara,

Em lugar de cotó arco e taquara

Penacho de guarás em vez de gorra.

Furado o beiço, e sem temor que morra (MATOS, 1976, p. 109) 
os mesmos "beiços furados" e corpo pintado com urucu, que na Carta de Pero Vaz de Caminha (CASTRO, 2014, p.90) surgem como aspecto de noção e valorização estética no poema de Gregório de Matos aparecem como motivo para ridicularizarão. O segundo aspecto é o psicológico, retratado no trecho,

\author{
Alarve sem razão, bruto sem fé, \\ Sem mais leis que a do gosto, quando erra \\ De Paiaiá tornou-se em abaité. \\ Não sei onde acabou, ou em que guerra: \\ Só sei que deste Adão de Massapé \\ Procedem os fidalgos desta terra. (MATOS, 1976, p.109)
}

Ao descrever aspectos e valores culturais dos indígenas o poema inferioriza o autóctone diante da cultura europeia. Além do mais, afirma que é desse índio ridicularizado por seus costumes que advém a aristocracia baiana. É o índio "alarve", sem educação, um bárbaro, assim como o índio de Prosopopeia, de Bento Teixeira, que não tem fé como também se mostra os índios dos jesuítas ou, mesmo o de Caminha que ao enxergar o índio nu atribuía a sua nudez como inocência, da mesma forma que Adão no paraíso e, por isso, prontos a receber o evangelho. Até aqui o que podemos perceber da leitura desses textos dos tempos coloniais é a total estranheza e ignorância diante dos costumes, hábitos e crenças da cultura aborígene, o que na verdade está articulado ao processo de colonização do novo mundo.

Geralmente, entendemos a história como uma evolução linear do pior para o melhor. Isto existe, mas a história é dialética e contraditória. Como podemos perceber no olhar um pouco mais humanizado no pensamento crítico de Michel de Montaigne em seu ensaio, "Os Canibais", sobre a questão de relacionar o nativo, aborígene, o índio como "bárbaro" diante de todos os relatos que eram feitos sobre o índio:

(...) não vejo nada de bárbaro ou selvagem no que dizem daqueles povos; e na verdade, cada qual considera bárbaro o que não se pratica em sua terra. $\mathrm{E}$ é natural, porque só podemos julgar da verdade e da razão de ser das coisas pelo exemplo e pela ideia dos usos e costumes do país em que vivemos. Neste a religião é sempre a melhor, a administração excelente, e tudo o mais perfeito. A essa gente chamamos selvagens como denominamos selvagens os frutos que a natureza produz sem intervenção do homem. No entanto aos outros, àqueles que alteramos por processos de cultura e cujo 
desenvolvimento natural modificamos, é que deveríamos aplicar o epíteto" (MONTAIGNE, 2000: 195).

Contudo, há, sem dúvida, uma diferença entre o índio do contexto brasileiro, com o qual o processo mercantil precisava lidar em termos reais e o índio vislumbrado por Montaigne, já que o Iluminismo não precisava lidar com ele da mesma forma.

Ainda que possamos reconhecer que dentro de um mesmo período histórico os fatos possam levar, dentro de uma perspectiva particular, a fenômenos diferentes, como no tratamento dos índios como bárbaros por tantos poetas e no olhar humanizado diante do aborígene de Montaigne, é preciso compreender que existe em uma perspectiva geral e, portanto, maior e histórica o que Caio Prado Júnior denominou como "sentido da colonização". Para o autor, este sentido é percebido "não nos pormenores de sua história, mas no conjunto dos fatos e acontecimentos essenciais que a constituem num largo período de tempo" (PRADO JR., 61, p.13). A nós interessa pensar, nestes termos, em como fomos direcionados a transfigurar o índio, um elemento autóctone que sofre um genocídio violento em suas inúmeras esferas, já que lhe foram negados durante todo o processo de colonização e até mesmo nos dias atuais o direito de ser índio dentro de tudo que isso engloba - terra, costumes, crenças - de acordo com a necessidade. Em termos literários, até aqui, sabemos que os índios foram usados na literatura como carentes de catequese, foram utilizados como cenário para defesa do colonizador em detrimento aos jesuítas e que foram transfigurados em sua forma de ser, de pensar e de agir para, finalmente, serem dignos de representar a gênese do povo brasileiro.

Diante disso e a partir das considerações de Caio Prado Júnior é possível perceber que essa transfiguração do índio "se forma de uma linha mestra e ininterrupta de acontecimentos que se sucedem em ordem rigorosa, e dirigida sempre em determinada orientação" (PRADO JR., 61, p.13). Mesmo que Caio Prado esteja se referindo à história não podemos e nem devemos encarar a literatura como algo externo a ela e, sendo assim, podemos avaliar que a construção literária que tem o índio, como protagonista ou mesmo como cenário, desde o início passando pelas crônicas dos viajantes até sua consolidação com os românticos no século XIX, sempre esteve desenhada por esta "linha ininterrupta" de total desprezo do índio e da conservação de seus costumes e crenças. Se no século XVI os índios foram usados para, através da catequese, se tornarem "aliados" no processo de colonização, nos séculos 
posteriores eles serviram, respectivamente, para justificar o processo violento de aculturação e em seguida como base para a construção e implementação de um sistema literário brasileiro.

De fato, o sentido de haver uma literarização do elemento indígena é que o índio só se torna protagonista porque foi dizimado. É sua dizimação que consente seu sentido na representação.

Em meados do século XVIII os autores e os letrados brasileiros começam a buscar, de alguma forma, produzir uma literatura própria. Esse movimento pode até ser compreendido como uma possível configuração para um sistema literário, ainda que precária se compreendermos o sistema como algo que deve ser orgânico ${ }^{8}$. Até o Arcadismo a literatura que produzíamos era feita ou por europeus ou por homens que estudaram na Europa, tratava de religião e dogmas e assim estavam a serviço da catequese e, consequentemente, serviam de justificava à colonização.

No período do Arcadismo atingimos um número maior de leitores das obras produzidas aqui - que é um dos requisitos no conceito elaborado por Antonio Candido sobre o sistema literário - e com a possível maior circulação das obras literárias iniciamos um longo processo na constituição de um sistema literário:

À medida que se prossegue no tempo, vai-se passando de um Arcadismo tout court (os sonetos de Cláudio Manuel da Costa, por exemplo), ao engajamento pombalino da épica de Basílio da Gama, para chegarmos enfim à sátira política, velada no Gonzaga das Cartas Chilenas, mas aberta no Desertor de Silva Alvarenga. (BOSI, 1994, p.55).

Se até o Barroco, para Candido, a terra nova produzia manifestações literárias, com o Arcadismo é possível afirmar que iniciamos o processo de constituição de um sistema literário, tendo em vista os três princípios, segundo Candido - primeiramente, um grupo de autores que estivessem envolvidos por um propósito em comum, em seguida, o surgimento de um público leitor e, por fim, obras que ao passarem a ser conhecidas constituem um legado de tradição.

O Arcadismo, como sabemos, não anulou características das produções dos períodos anteriores, mas acrescentaram novas características, como no esquema feito por Candido,

\footnotetext{
${ }^{8}$ Antonio Candido no texto Letras e ideias do período colonial afirma que um sistema é orgânico quando "é capaz de dar lugar a uma vida literária regular, servindo de base a obras ao mesmo tempo universais e locais".(CANDIDO, 2006,p. 99)
} 
1)que a confiança na razão procurou, senão substituir, ao menos alargar a visão religiosa; 2) que o ponto de vista exclusivamente moral se completou - sobretudo nas interpretações sociais - pela fé no princípio do progresso; 3) que, em lugar da transfiguração da natureza dos sentimentos, acentuou-se a fidelidade ao real.

A partir dessas características nos encaminhamos para a independência política, além de alguma emancipação intelectual. Neste contexto surge O Uraguai (1769), de Basílio da Gama (1741-1795), poema que se propõe a relatar o massacre dos indígenas provocado nas missões dos jesuítas, especificamente, dos Sete Povos das Missões.

Precisamos ressaltar que no período arcádico a literarização do índio estava ligada a uma disputa ideológica, tendo em vista que, de um lado, estavam obras como Caramuru (1781) que tratavam da catequização jesuítica e, por outro, o cenário do pombalismo como pano de fundo d'O Uraguai. Para Candido (2006a, p.103), o pombalismo era,

muito propício ao Brasil e aos brasileiros, e exemplo do ideal setecentista de bom governo, desabusado e reformador. Para uma colônia habituada à tirania e carência de liberdade, pouco pesaria o despotismo de Pombal; em compensação, avultaram a sua simpatia pessoal pelos colonos, que utilizou e protegeu em grande número, assim como os planos e medidas para o nosso desenvolvimento.

Sobre $O$ Uraguai nos interessa destacar: seu teor antijesuitismo e encantamento notório pelos índios e sua cultura. Assim como nos parece confirmar o esclarecimento de Antonio Candido a respeito de O Uruguai (1769), “um poema narrativo de assunto épico e político, banhado por um lirismo eterno ou heroico que permite ver com simpatia a vida do índio brasileiro“(1970, p. 172)

Alcmeno Bastos, afirma que,

não há acordo no que se refere à possível brasilidade do poema. Nunca passou despercebida certa contradição entre o propósito declarado de exaltação do herói português e a indiscutível simpatia manifestada em relação aos índios, funcionalmente seus antagonistas, o que poderia ser tomado já como manifestação do indianismo. Afinal, a favor de quem estaria o poeta? (BASTOS, 2011, p.77)

Dessa forma, n'O Uraguai a presença do índio, através de Sapé e Cacambo, é engradecida pela bravura e pela altivez de seu caráter:

Já para o nosso campo vêm descendo

Por mandado dos seus, dous dos mais nobres.

Sem arcos, sem aljavas; mas as testas

De várias e altas penas coroadas, 
E cercadas de penas as cinturas,

E os pés, e os braços e o pescoço. Entrara

Sem mostras nem sinal de cortesia

Sepé no pavilhão. Porém Cacambo

Fez, ao seu modo, cortesia estranha. (GAMA, 1998, p. 56)

Contudo, para que possamos compreender a situação e representação do índio em O Uraguai é preciso, primeiramente, que possamos nos situar nos acontecimentos históricos que envolvem o Sete Povos das Missões e que resultam no poema que aqui analisamos. Após a anulação do Tratado de Tordesilhas surge, em 1750, o Tratado de Madri que estabelece uma nova remarcação de territórios aos índios guaranis. Ao violento conflito, entre índios guaranis e as tropas espanholas e luso-brasileiras no sul do país, que foi ocasionado por esse evento denominou-se Guerra Guaranítica.

Os guaranis que fugiam do massacre a cada vez que se reestabelecia uma nova reorganização de fronteiras, ou dos bandeirantes que aprisionavam os índios com intuito de submetê-los ao trabalho escravo, buscavam se refugiar juntamente aos jesuítas. Todavia, Sete Povos das Missões não era um paraíso de liberdade para os indígenas, já que os índios não possuíam liberdade para a prática de seus cultos, pelo contrário, caso mantivessem suas práticas corriam o risco de serem expulsos ou de sofrerem clausura, jejuns e "castigos" físicos por parte dos jesuítas.

Neste cenário histórico trágico, O Uraguai, de Basílio da Gama, se vale da inserção do índio na poesia nacional como possibilidade estética de narrar toda a força impositora da Europa contra América. Das críticas que temos sobre o texto de Basílio da Gama um ponto que aqui nos parece bastante relevante é a questão de uma possível brasilidade do poema. Veríssimo (1998), em seu texto História da literatura brasileira, contrapõe as manifestações do índio entre $O$ Uraguai e as obras indianistas do Romantismo. Segundo o autor, em Basílio da Gama o nativo surge como "um artifício poético; o índio entra como uma necessidade de assunto, um simples recurso estético ou retórico", enquanto que para os românticos "o índio passa de acessório a essencial, é ele o assunto e o objeto do canto" (VERÍSSIMO, 1998, p. 424). O índio do Arcadismo ainda se apresenta como selvagem, assim como os relatos não ficcionais já analisados anteriormente, como elemento de empecilho para desbravadores de terras e riqueza, ou ainda, como aquele que poderia ser 
escravizado, sempre em posição desfavorável diante do herói, rude e desprovido de artifícios que o colocasse em nível de igualdade. E, mesmo quando se levanta o índio não demonstra autonomia, mas se apresenta manipulado pelos jesuítas, como nos versos do Canto I:

Quem poderia esperar que uns índios rudes

Sem disciplina, sem valor, sem armas,

Se atravessassem no caminho aos nossos,

E que lhes disputassem o terreno!

Não sofrem tanto os índios atrevidos:

Juntos um nosso forte entanto assaltam

E os padres os incitam e acompanham.

Que, à sua discrição, só eles podem

Aqui mover ou sossegar a guerra. (GAMA, 1980, p. 42 )

Sabemos, contudo, que $O$ Uraguai (1769) não era um texto que se voluntariasse sem maiores interesses à defesa dos índios e seu genocídio dizimador. Antonio Candido em seu texto A Dois séculos D’O Uraguai já esclarece que, "Em 1769 foram publicados o dito poema, Epitalâmio da excelentíssima senhora Dona Maria Amália e O Uraguai, este, segundo Kaulen, por encomenda de Pombal e usando dados fornecidos por ele" e ainda mais, que "nos seus aspectos mais ostensivos, o poema serve aos mesmos fins de propaganda que o panfleto". (CANDIDO, 2011, p. 130,131). E entre portugueses e índios, nesse dilema entre colonizador e aborígenes o poeta insere no poema um terceiro elemento, no caso, o jesuíta.

Nesta mesma tríade criada pelo poeta, entre português, jesuíta e índio, ele é traído por suas motivações, já que era preciso exaltar o português, execrar o jesuíta e ao índio sobrava, como caminho mais fácil deixá-lo ligado ao natural como "recurso estético", como já nos referimos à fala de Antonio Candido. O poema de Gama, de fato, se opõe aos jesuítas e, por conseguinte a catequese dos indígenas, todavia, o faz em defesa do projeto de Pombal que disputava com os jesuítas o modelo colonialista que deveria se estabelecer no momento.

Basílio da Gama não era um estudioso da vida e dos costumes dos índios, como mais tarde se revelaria Santa Rita Durão (1722-1784), e, talvez, por isso, O Uraguai possua este traço mais lírico e menos engajado nos revelando muito mais um índio que compõe um cenário do que um elemento essencial ao texto. Mesmo percebendo no poeta árcade uma certa 
identificação com o índio e a defesa das suas causas ele impõe a sua visão de mundo ilustrada a partir da defesa ideológica do pombalismo, que, segundo Candido (2004, p. 7), "estava mais perto daquilo que no tempo era progresso. Mesmo sendo progresso de déspota esclarecido, useiro da brutalidade e do arbítrio".

Caramuru (1781), assim como O Uraguai, foi um texto que de forma geral se fixou pelos românticos como um dos textos fundadores da literatura brasileira. Todavia, ao contextualizarmos o poema na própria trajetória intelectual do autor e, ainda, em sua época de composição e publicação, não podemos negar seu caráter enaltecedor da colonização portuguesa. Esta leitura "nacionalista" é posterior à obra de Durão, já que não é provável que o autor presenteasse ao rei de Portugal, que pretendia reinstalar o sistema colonial, com um texto nacionalista.

Sabemos que os românticos buscavam uma identidade nacional que era inexistente ou, pelo menos, embrionária e que para justificá-la se valeram de uma leitura seletiva dos textos do período colonial no intuito de classificá-los como nacionalistas. Para Durão, o Brasil só teria algum futuro caso se tornasse uma extensão de Portugal e de seu legado católico, discurso coerente aos propósitos do rei. Contudo, podemos perceber em Caramuru a busca de Durão por integrar ao mundo americano - com destaque para os índios e a natureza - a expressão culta das fontes civilizatórias, como no trecho a seguir:

Dormindo estava Paraguaçu formosa,

Onde um claro ribeiro a sombra corre;

Lânguida está, como ela, a branca rosa,

E nas plantas com a calma o vigor morre;

Mas buscando a frescura deleitosa

De um grão maracujá, que ali discorre,

Recostava-se a bela sobre um posto,

Que, encobrindo-lhe o mais, descobre o rosto. (Canto II, XVI)

Neste cenário criado por Durão temos a idealização de um lugar tranquilo e pacífico o que se revela um intervalo diante dos constantes movimentos de violência. Os conflitos gerados no poema são em nome da fé e da justiça justificada como forma, aliás, como única forma, de salvação dos índios. Sabemos, portanto, que considerando as alterações, essa ideia do índio salvo pela fé também esteve presente em outros momentos da literatura, 
sobretudo no Romantismo. Sobre essas modificações, mas com permanência de tantos elementos, Antonio Candido (2009, p.327) esclarece:

(...) como as formas e temas tradicionais já se iam revelando insuficientes para traduzir os modernos pontos de vista, foi uma fratura salutar, que permitiu sensível desafogo, devido à substituição, ou quando menos reajuste dos instrumentos velhos, com evidente benefício da expressão.

Dessa forma, em Caramuru são claros os aspectos marcantes da identidade portuguesa, como a fé católica, o que também podemos perceber no jogo de conflito cósmico, baseado no mito judaico-cristão, entre Deus e o Diabo relacionados com o encontro entre europeus e nativos. Obviamente, identificando a ordem e o divino ao europeu e relacionando o índio à desordem e ao demoníaco. Assim, como fazia Anchieta em seus autos e sermões.

No livro de Santa Rita Durão, Caramuru, o canibalismo, a barbárie e a selvageria são "corrigidos" pelo processo violento da colonização legitimado através das armas do personagem Diogo. Aliás, a morte dos índios é justificável e necessária para que a terra atinja sua dimensão paradisíaca e, assim, se redima do mal. A intervenção do narrador na cena em que os índios devoram ainda crus os náufragos, afirmando que a Europa também teria vivido sua era de barbárie, mas que havia superado a partir da conversão ao cristianismo, traça um paralelo entre o índio e o europeu atribuindo-lhe alguma humanidade, mesmo que o reconhecendo como primitivo. O Uraguai e Caramuru aparecem não com o teor nacionalista que os escritores românticos tentaram atribuir, mas sim como legitimações do Brasil colônia. O que não chega a ser culpa desses artistas, já que diante da situação em que estavam e do desejo eminente de construir um sistema literário brasileiro a leitura seletiva que fizeram só poderia ser a de encontrar algo "nacionalista" nas obras de Basílio da Gama e Santa Rita Durão.

Em Caramuru também está presente a aversão à antropofagia praticada pelos índios e Durão demonstra ela já em seu primeiros versos quando relata o naufrágio de Diogo Álvares nas costas da Bahia e a recepção dos indígenas,

Correm depois de crê-lo, ao pasto horrendo;

E, retalhando o corpo em mil pedaços,

Vai cada um, famélico, trazendo,

Qual um pé, qual a mão, qual outros os braços;

Outros na crua carne iam comendo, 
Tanto na infame gula eram devassos.

Tais há que as assam nos ardentes fossos. (Canto I, XVIII)

Em seguida, o poeta tratar de afirmar que não são os índios os únicos a praticarem o canibalismo e atribui o fim da prática à conversão ao cristianismo,

Não era aquela infâmia (o canibalismo), praticada

Só dessa gente miseranda e bruta:

Roma e Cartago o sabe no noturno,

Horrível sacrifício de Saturno[...]

Que horror da humanidade! Ver tragada

Da própria espécie a carne já corrupta!

Quanto não deve a Europa abençoada

A fé do Redentor que humilde escuta (Canto I, XVIII)

O Caramuru, segue assim, mesmo que carregado no título de uma palavra indígena que se refere ao português, com a temática centrada ao louvor do índio, porém que presta tributo a ação do colonizador português. Seu título, em termos simbólicos, segue como um infeliz desenho do que o poema propõe e cumpre. A formação católica de Durão apenas reforça as distâncias ideológicas e religiosas em que estão os indígenas e os colonizadores europeus - reforçando a ideia pré-concebida de que os índios estão em uma situação inferior diante do europeu - sua obra surge como ferramenta legitimadora do processo violento de colonização e aculturação.

No persoagem Diogo Alves, colonizador português, há uma ambiguidade fundamental para esta análise,

Na perspectiva da nossa formação histórica, Diogo - Caramuru é paradigma no encontro das culturas, que compuseram a sociedade brasileira e dialogaram muitas vezes em pé de igualdade, até que a ocidental predominasse em todos os setores, a partir da segunda metade do século XVIII, quando o Morgado de Mateus proibiu o uso da língua geral em São Paulo, seu último reduto em zona civilizada. A essa altura, já Durão e os seus contemporâneos se encontravam numa posição-chave, que permitiu interpretar e sistematizar o passado com certa coerência. (CANDIDO, 2006a, p.190)

Dessa forma, podemos analisar o herói de Caramuru de forma ambígua, tendo em vista que, o seu herói é concomitantemente Diogo, o colonizador, e também Caramuru, o 
náufrago identificado aos indígenas. Por isso, a obra de Durão foi tão facilmente retomada pelos românticos, uma vez que seria quase que espontâneo aderir a uma das vertentes de Caramuru, já que essa obra pode ser entendida tanto como expressão da colonização quanto do nativismo.

A literarização do indígena ao decorrer da literatura brasileira só revela que a questão do índio não é algo que tenha se restringido ao passado nacional. Após essa construção temporal da presença do índio, nas obras aqui analisadas, sabemos que a representação do indígena não pode ser observada como um elemento desconectado da literatura e nem da nossa vida social.

Diante disso, consideramos que o elemento estético indígena é transfigurado em nossa literatura em um processo que evidencia a ligação direta entre o índio e o processo contraditório da realidade nacional. Temos, portanto, na literatura a questão do índio integralizada à história, já que é através da literatura que temos representados o índio em relação ao europeu e seus descendentes, além da imposição da cultura, credos e crenças realizados pelo processo de colonização. 


\section{CAPÍTULO 2}

\section{INDIANISMO E O ÍNDIO POSSÍVEL}

Neste segundo capítulo analisaremos como os escritores brasileiros principalmente, José de Alencar- do Romantismo, no século XIX, encaram problemas e questões do tipo: Como foi nosso passado colonial? Quem são os brasileiros? Como o índio dizimado surge como possibilidade de representação brasileira? Como resolver os problemas brasileiros?

Como vimos no primeiro capítulo, a Literatura Brasileira tematiza o índio desde sempre e, junto com essa tematização, podemos observar que a literatura assume um papel eficaz na imposição da cultura do colonizador. Os autores das cartas, crônicas, sermões, poemas, autos e romances eram todos ligados diretamente aos interesses da igreja ou ao império luso e através da literatura trataram de impor a crença e a política do colonizador. $\mathrm{O}$ índio então surge desde as manifestações literárias ${ }^{9}$ como matéria temática moldada e manipulada para servir aos interesses do colonizador, ou do jesuíta, ou ainda do colono europeizado que almejava a posição de domínio do colonizador.

Todavia, é importante ressaltarmos o caráter de discurso contra-hegemônico da literatura, uma vez que é a partir da literatura que surge a possiblidade figurada de confronto entre indígena e colonizador. O professor e crítico literário Hermenegildo Bastos, em seu livro Literatura e colonialismo: rotas de navegação e comércio no fantástico de Murilo Rubião (2001), esclarece essa questão,

(...) a literatura praticada em condição colonial tem seu comprometimento com o projeto nacional das elites, mas também a possibilidade de produção do discurso contra-hegemônico. Partimos de uma desvantagem, uma vez que a literatura, como fator de civilização, serviu fundamentalmente ao colonizador no seu propósito de construção de um imaginário dócil aos seus interesses. A literatura é, entretanto, um lugar de conflitos e contradições, e o imaginário, por mais dócil que seja, sempre contém uma força transgressora. (BASTOS, 2001, p. 15)

Neste sentido buscamos compreender, inicialmente, no primeiro capítulo com as obras analisadas em como as manifestações literárias que tematizavam o índio, ainda que

\footnotetext{
${ }^{8}$ No livro Formação da Literatura Brasileira, Antonio Candido classifica as produções feitas no período das cartas de cronistas, sermões e período colonial como "manifestações literárias".
} 
buscassem criar a imagem de um índio dócil baseado no bom sauvage, acabava revelando na maioria das vezes as contradições e a violência impositiva e dizimadora da nossa colonização. Neste capítulo observaremos como os romancistas brasileiros se apropriaram do índio elegendo-o como personagem central do projeto de elaboração de uma literatura própria e de constituição da nação, reforçando a tese de que as letras não só molduraram, mas também serviram de sustento político nesse processo de afirmação de independência em relação a Portugal. Alguns fatos colaboraram para que a insatisfação com a dependência da metrópole começasse a surgir. Dentre eles podemos destacar o fato de Portugal ser um país atrasado e o estatuto de dependência ${ }^{10}$, vigente na época, impedir que as classes superiores ocupassem cargos de liderança e maior prestígio.

Certamente, em termos culturais também vivíamos um estado de atraso, tendo em vista que não tínhamos universidades e nem bibliotecas em números significativos e nem qualidade. Contudo, quando a Família Real Portuguesa muda-se para o Brasil o cenário se reconfigura. Antonio Candido (2002, p. 10) chega a afirmar que é a partir desse acontecimento que "inicia-se um processo de independência virtual, tornada efetiva em 1822". Obviamente, a proclamação da independência se deu como manobra política do então imperador D.Pedro I, que manteve as classes dominantes com seus privilégios e posições, ignorando por completo questões que estruturavam a vida colonial como a escravidão dos negros.

Diante das mudanças ocasionadas pela transferência da Família Real e tudo que ocorreu depois disso, Candido (2009, p. 241) classifica as produções nas letras em duas categorias: "um ciclo literário de pleito ao Rei" e as produções feitas por "homens de maior trato com a Europa que encaravam os fatos com realismo". Contudo, independentemente do objetivo e das intenções dessas produções, precisamos considerar o que Candido (2009, p. 241) define como "literatura vinculada à coisa pública" como um momento importante marcado pela promessa de cultura autônoma e livre que começam a ressoar nas artes e nas letras.

Esse sentimento de busca por uma autonomia política e cultural inicia-se como processo a partir do fim do século XVIII e desencadeia-se com a confiança adquirida pelos

\footnotetext{
${ }^{10} \mathrm{O}$ estatuto da dependência estabelecia a dominação da colônia pela metrópole. Dessa forma, a metrópole comprava da colônia matérias-primas por valores baixíssimos e vendia produtos manufaturados por preços exorbitantes. Esse pacto seguia lógica mercantilista de acúmulo de metais preciosos e de centralização econômica nas mãos do governo.
} 
intelectuais, após a vinda da Família Real e, consequentemente, com os acontecimentos sociais e culturais decorrentes dessa mudança. A cidade do Rio de Janeiro se estabelece como a capital em que os escritores moravam e produziam, onde estavam a maioria de seus leitores o que, de certa forma, também contribui para a construção da identidade, no aspecto nacional, desses escritores.

Interessa-nos compreender que as ideias iluministas, que vinham da Europa e que seriam trazidas - para um contexto político e estrutural contraditório como era o Brasil estavam diretamente ligadas com o desejo de nação e independência dos intelectuais e escritores brasileiros inseridos no processo de modernização do país. Essas ideias ligaram-se, inevitavelmente, ao desejo pulsante de independência estética em relação a Portugal. Para alcançar esse objetivo ou, pelo menos, para lançarem-se nesse desafio os escritores românticos precisavam destacar a realidade brasileira diferenciando-nos de Portugal pela natureza e, consequentemente, pela figura do índio. Além disso, encararam como necessidade uma diferenciação linguística que marcasse a distinção - mesmo na mesma língua - entre a língua portuguesa falada aqui e em Portugal.

Paulo Arantes, em seu texto Nação e Reflexão (2006), ao refletir sobre o texto de Benedict Anderson (1989), esclarece que a ideia de "comunidades imaginadas" e, por conseguinte, de nação nascem das leituras diárias dos jornais locais, mas também dos romances - uma vez que, ambas as leituras traziam um cenário cotidiano comum aos seus leitores - além de, trazerem como referência a pátria e o local levando eficiência na produção de sentimentos comuns de uma comunidade:

Foi o caso do romance, como era de se prever, numa palavra, o romance como um instrumento privilegiado de descoberta do país e de interpretação social, como Antonio Candido caracterizou o aparecimento da ficção entre nós, quando a ex-colônia recentemente emancipada também estava carecida não só de se tornar politicamente viável, mas igualmente "emocionalmente plausível" (ARANTES, 2006, p.35)

Dessa forma, caberia aos escritores, segundo Antonio Candido (2002, p.63),

Não apenas focalizar a realidade brasileira, privilegiando as diferenças patentes na natureza e na população, mas elaborar a expressão que correspondesse à diferenciação linguística que nos ia distinguindo cada vez mais dos portugueses, numa grande aventura dentro da mesma língua.

Dos escritores românticos que assumiram com maior empenho a questão da identidade nacional pelo aspecto da linguagem, José de Alencar é o que mais se destaca. $\mathrm{O}$ 
fato de que no século XIX boa parte dos escritores brasileiros já se formava no Brasil contribuiu para uma busca da forma brasileira de escrever.

Para melhor compreendermos o Romantismo no Brasil é preciso esclarecer e relembrar que o Romantismo na Europa surge no cenário histórico entre a segunda metade do século XVIII e a primeira do século XIX. Nesse contexto estavam a Revolução Francesa, que ocorre em 1879, e a Revolução Industrial, essas revoluções eram inspiradas pelo iluminismo e mudaram definitivamente o cenário social, político e econômico da Europa, pois desencadearam mudanças estruturais na sociedade da época, além de formarem as condições essenciais para ascensão e permanência da classe burguesa. Diante desse cenário há uma alteração significativa no equilíbrio das nações o que provoca um forte sentimento nacionalista.

De fato, é contra os princípios políticos absolutistas que os programas políticos revolucionários do século XVIII se levantam e, consequentemente, tais ideias ultrapassam os limites das metrópoles e chegam até as colônias despertando também nas Américas desejos libertários e nacionalistas. Esses anseios, tão essenciais ao Romantismo, nos aproximavam do cenário Europeu, mas também despertavam um movimento conflitante e contraditório de nos diferenciarmos da metrópole, a partir do desenvolvimento de uma literatura que tivesse elementos próprios.

No entanto, esse desejo de diferenciação esbarrava no sentimento conflitante de buscar equivalentes nos modelos europeus. Antônio Paulo Graça (1998, p. 14-17) escreve sobre o desafio do deslocamento do índio para o formato europeu,

Quando o romancista americano (das Américas, bem entendido) resolve eleger o índio como personagem central, está, de fato, operando não apenas uma fusão conteudística - o índio como conteúdo - mas também estética, pois a inserção de tal personagem há de necessariamente impor estratégias, modos e meios de elaborar o romance. Além do mais, a criação de personagens, na literatura ocidental, é um processo que se arrasta por vinte e quatro séculos, pelo menos. Elaborar personagens a partir de um ser tão dissimilar na cultura, nos valores, hábitos e crenças consistiria, se bem sucedida, em verdadeira revolução ficcional.

Não podemos negar que o índio era mesmo um elemento legítimo do Brasil todavia, é preciso ressaltar que o índio só se torna protagonista porque foi dizimado e assim, não sendo mais necessário lidar com o índio real, inventa-se oportunamente um índio estético - o que só fortificava o movimento literário nacionalista que construía e apresentava o índio herói como produto legítimo dessas terras. Para elaborar os romances que serviriam como 
base sustentadora do movimento nacionalista era preciso forjar um herói aos moldes europeus. Roberto Schwarz (1992, p.35) chega a dizer que, "o romance existiu no Brasil, antes de haver romancistas brasileiros" o que implica que nossos parâmetros não se encontravam e nem eram, pelo menos em parte nossos, mas se tratavam de pressupostos alterados para se encaixarem no desejo de nação e de literatura que pretendiam criar nossos autores. Essas adaptações e ajustes à realidade nacional do Novo Mundo subvertiam a estética e a política, a partir da importação desse formato, no caso o romance, e da criação de personagens - que durante o romantismo se tornaram padrão - adaptados a um conjunto de valores e ideais que já existiam e que muito se diferenciavam dos nossos.

Para que fosse possível essa elaboração estética que criou o índio-herói para o Romantismo alguns fatores contribuíram, como, por exemplo, a condição de homem que os jesuítas concederam aos autóctones e a abolição de sua escravatura no século XVIII. De certo, essas concessões só contribuíram de forma favorável para estetização do índio graças à sua quase dizimação, e isto só acontece ao índio que morava nas áreas mais afastadas do país e, principalmente, o índio do passado.

Interessa-nos saber que o índio forjado e transfigurado pelos romancistas brasileiros era bastante baseado no mito do bon sauvage de Rousseau ${ }^{11}$, o homem bom, naturalmente bom e não corrompido pela civilização. Os índios brasileiros sofreram em seu processo de modificação na literatura e em outras artes a influência da noção filosófica do ameríndio que se compara a Adão, no estado que antecede a queda do Éden, obviamente, e que, portanto se apresenta como puro e bom. É esse o olhar que os românticos brasileiros jogam na matéria estética que se tornaria o índio dentro de uma leitura, ou melhor, releitura que fariam da "infância" da nossa literatura sob a orientação histórico-nacionalista. Se na Europa os países começavam a se organizar como nação e no Novo Mundo levantavam-se guerras pela independência - influenciadas pela dos Estados Unidos no final do século XVIII - aqui no Brasil já havíamos nos libertado desde 1822 de Portugal e agora buscávamos construir uma independência nacional.

O nacionalismo surge então, nesse período, aliado à literatura com forte papel político em nosso país. Mesmo que a construção da identidade fosse marcada, pelos escritores e intelectuais, com elementos que fossem genuinamente brasileiros - como a natureza e os

\footnotetext{
11 “A teoria do bom selvagem”, de J. J. Rosseau (1712-1778) surgiu em 1755, e diz que o homem por natureza é bom, nasceu livre, e sua maldade advém da sociedade - mais precisamente do processo civilizatório- que impõe e legitima a servidão.
} 
índios - ainda era preciso fazer resistir elementos "civilizados" europeus, que implicaria na coibição de eventos e costumes diferentes. Dessa forma, para Candido (2006b), a literatura desse período se tornou uma ferramenta eficiente do processo colonizador, fato que o autor justifica inclusive no nível popular ao relembrar, que:

as restrições opostas pela administração colonial a uma expansão possível das culturas dominadas. Assim, a Câmara da Vila de São Paulo estabelecia penalidades para os brancos, e considerados tais, que participassem dos festejos nativos ou os promovessem. (CANDIDO, 2006b, p. 164-165)

Se o romantismo na Europa surge na classe burguesa criada e fortificada com a Revolução Francesa embebida dos ideais liberais, no Brasil nós ainda éramos um país que vivia a escravidão como modo de produção e ainda assim ansiávamos nos inserir em uma tradição literária que tentava acompanhar os passos da Europa e seus ideais liberais, estava montada a "comédia ideológica" (SCHWARZ, 2014, p.48). Dessa forma, não era possível pensar no negro como o elemento que sustentaria o material cultural constitutivo de nacionalidade. Por isso, o negro e a escravidão foram completamente ignorados pelos romancistas, já que não era possível construir uma identidade literária valendo-se da natureza ignominiosa da sociedade escravista. Antes era preciso construir um passado que já fosse genuinamente nacional, a partir do qual seria possível reconhecer aqueles que haviam contribuído para sua criação.

Os escritores românticos brasileiros empenharam-se na elaboração de um projeto de nação que fosse capaz de criar uma particularização do Brasil em relação à Europa e que pudesse revelar-se como uma literatura nacional distinta e autônoma da portuguesa. Essa busca pelo nativismo que Antonio Candido (2006b) chamou de "tendência genealógica", buscava um elemento que representasse o espírito nacional e que parecia se realizar na idealização romântica do indígena. Mais do que isso, era preciso justificar o presente resgatando elementos do passado, à maneira de construir as próprias origens.

Para Antonio Candido, a tendência genealógica "corresponde à formação da consciência das classes dominantes locais que, depois de estabilizadas, necessitavam elaborar uma ideologia que justificasse a sua preeminência na sociedade" (2006b, p.171). Dessa forma, os escritores românticos tinham a difícil missão de criar uma história positiva para a mestiçagem brasileira e para o contato entre as culturas, além de excluir completamente o negro dessa mesma narrativa. 
Assim, por definição de Candido (2006b, p.172), a "tendência genealógica" consiste em escolher no passado local os elementos adequados a uma visão que de certo modo é nativista, mas procura se aproximar o mais possível dos ideais e normas europeias.

Diante desse contrassenso político e ideológico os escritores brasileiros desafiaram-se a (re) construir um índio estético que fosse capaz de equivaler ao soldado medieval como aquele que, de fato, seria o responsável por nos fazer reconhecer e até mesmo nos orgulhar de nossa identidade literária. Assim, segundo Flora Süssekind (1993, p.454) "abrir a cortina do passado, tirar um Brasil-nação de lá: esta a tarefa indiscutível do escritor romântico".

Diante dessa invenção, o índio se torna, assim, o personagem central na busca por uma tradição histórica. Os escritores românticos não hesitaram em utilizar a língua e os costumes dos indígenas como estoque estético para a construção dessa tradição e, dessa forma, mais uma vez o nativo servirá como matéria prima em um momento histórico e político.

Contudo, Flora Süssekind (1993, p.457) chama atenção para uma "espécie de imaginação geográfica todo-poderosa na escrita dos românticos brasileiros", o que se justificava pela falta de um passado glorioso e grandes tradições locais que havia na Europa. Assim como também buscou compreender Candido (2002, p.90),

no Brasil não tinha havido batalhas memoráveis, nem catedrais, nem divinas comédias, - mas o Amazonas era o maior rio do mundo, as nossas florestas eram monumentais, os nossos pássaros mais brilhantes e canoros.

Esse orgulho de uma natureza grandiosa e própria surge para os brasileiros como um sentimento que deveriam sentir de si mesmos e de sua história. Por isso, a natureza era sempre reivindicada pelos românticos neste processo de busca pela nacionalidade que é assumido pela literatura com intuito de configurar uma ideia nacional de pátria. Alencar (1980, p. 81) reivindica essas "cores" em sua crítica a A Confederação dos Tamoios (1856), de Gonçalves de Magalhães, "Por que não lhe dás as cores de tua paleta, a forma graciosa de tuas cores, a harmonia das auras da tarde? Por que não arrancas das asas de um dos teus pássaros mais garridos a pena do poeta que deve cantar-te".

Assim, essa natureza imaginada e mitificada se levanta na literatura com papel fundamental na constituição dos ideais nacionalistas de pátria. Além disso, outro pensamento nativista se organizava em alguns escritores românticos - como, por exemplo, José de Alencar 
- a instalação de uma língua que se diferenciasse da língua portuguesa falada em Portugal. Dessa forma, o romantismo surge como o momento propício para a busca pela fixação de uma língua literária brasileira.

Contudo, era preciso compreender que ao se referirem a uma língua brasileira de forma alguma esta seria sinônimo de língua indígena, mesmo que muitos elementos lexicais da língua tupi, principalmente, estivessem presentes na expressão literária. No entanto, se por um lado, os românticos brasileiros empenhavam-se em elementos que marcassem a diferenciação com a metrópole portuguesa, por outro, era preciso não se distanciar de Portugal, pois eram a língua e a religião herdadas que nos conferiam status de civilizados. Assim, para Joaquim Noberto,

ao menos cá de mim para mim tenho, que quando disser língua portuguesa, entenderão por tal o idioma que se usa na velha metrópole, e quando disser língua brasileira, tomarão por tal a que falamos, que é quase aquela mesma, mas com muitas mudanças. (Tomo III, p. 100)

Como temos tentado esclarecer, o indianismo é indiscutivelmente um dos elementos do nacionalismo literário e sua expressão não se limitava apenas aos protagonistas e à inserção de costumes indígenas na obra literária, mas também se tornava presente na inclusão do vocabulário tupi-guarani - língua que se convencionou atribuir aos índios negando a existência de outras línguas indígenas. Todavia, mais do que a inserção de vocábulos do tupi-guarani, Alencar busca recriar o tupi, como esclarece Flora Süssekind (1993, p. 466),

com aura poética Alencar enxerga o tupi e procura "traduzi-lo". Imagina uma língua tupi e, a partir dela, multiplica, então, onomatopeias, símiles, frases "mais simples e concisas" nos seus romances indianistas para que se aproximem, assim, das "tendências do espírito" dos selvagens.

Nesse projeto que visava uma nação independente e uma literatura própria podemos destacar autores como Gonçalves Dias e Gonçalves Magalhães, mas nenhum teve mais destaque com o romantismo indianista do que José de Alencar. Segundo Antonio Candido (2006b, p. 147), estes "foram considerados pelos contemporâneos como realizadores de uma literatura que finalmente era nacional, porque manifestava a nossa sensibilidade e a nossa visão das coisas". Candido ainda considera esse momento como o ápice da "tendência genealógica" que consistia na negação dos valores que estavam de alguma forma ligados à colonização. 
A tríade indianista alencariana, com as obras $O$ Guarani (1857), Iracema (1865) e Ubirajara (1874) sustentou a base do indianismo ao criar três personagens distintos, em momentos diferenciados, mesmo que tratando de um mesmo elemento indígena. Seus protagonistas expuseram o índio como épico, mito e lenda e é devido a essas possibilidades estéticas criadas pelo autor que escolhemos a obra de Alencar como o aporte para análise do indianismo no romantismo brasileiro reconhecendo-a como material possível de sublinhar as transformações e relações entre fato histórico e fato estético.

Para Alencar, assim como para outros autores indianistas, ao lermos um romance indianista deveríamos ser capazes de ler as Américas. Segundo Bosi (1992, p. 186), “Alencar empenha-se na construção ideal de uma nova nacionalidade: o Brasil que emerge do contexto colonial". As obras alencarianas atraíam os leitores de sua época porque concentravam dois aspectos literários estritamente românticos: o sentimentalismo e o heroísmo.

Dessa forma, enquanto o romantismo europeu tinha como características principais os ideais libertários e a luta por não reproduzir o modelo da época, no Brasil, além disso, somavam-se aspectos que o particularizavam como, por exemplo, o culto a natureza e a tentativa de se diferenciar das tendências europeias. Como dito pelo próprio Alencar, em Carta sobre a Confederação dos Tamoios (1980, p. 6),

Digo-o por mim: se algum dia fosse poeta e quisesse cantar a minha terra e as suas belezas, se quisesse compor um poema nacional, pediria a Deus que me fizesse esquecer por um momento as minhas ideias de homem civilizado.

Mais uma vez nos deparamos com a conflituosa e contraditória situação do escritor romântico brasileiro, tendo em vista que, se por um lado ele precisava construir uma postura capaz de produzir literatura para os termos europeus, por outro necessitava se distanciar para não ser mera cópia. Este esquecimento da civilização "por um momento" só nos revela a parcialidade na relação dúbia entre os valores indígenas e o do colonizador europeu.

Em $O$ Guarani (1857), primeiro livro da tríade indianista alencariana, há uma busca pela elaboração de sentimentos comuns da comunidade, que se constituem através da sonegação da própria história e, por exemplo, do genocídio cometido contra o povo indígena, além da mitificação do elemento local, o índio. O Guarani nos convidada a uma viagem ao passado colonial guiados pelo herói Peri, o herói estilo medieval, um gentleman que nos 
conduz na trajetória de mitificação do índio e que, em certo ponto, parece tornar justificável o processo violento da colonização, já que o índio se torna "civilizado" e, finalmente, apresentável dentro do nosso sistema literário e projeto de nação. Sobre $O$ Guarani, Antonio Candido (2002, p. 65-66) considera que, “amor, bravura, perfídia se combinam nele para dar ao leitor o espetáculo de um Brasil plasticamente belo, enobrecido pelas qualidades ideais do epônimo indígena".

Nas primeiras páginas do livro, Alencar utiliza da metáfora dos rios para explicitar seu posicionamento sobre o índio e sua relação com o colonizador,

Dir-se-ia que, vassalo e tributário desse rei das águas, o pequeno rio altivo e sobranceiro contra os rochedos, curva-se humildemente aos pés do suserano. Perde então a beleza selvática; suas ondas são calmas e serenas com as de um lago, e não se revoltam contra os barcos e as canoas que resvalam sobre elas: escravo submisso sofre o látego do senhor. Não é neste lugar que ele deve ser visto; sim três ou quatro léguas acima de sua foz, onde é livre ainda, como o filho indômito desta pátria da liberdade. (ALENCAR, 1998, p. 11)

É assim que se apresenta o índio de José de Alencar, como aquele que até se coloca em situação de submissão diante do colonizador, mas que não deveria, pois sendo assim perde sua "beleza selvática". Novamente retomamos o conceito basilar da construção do Indianismo, o homem natural, o bom selvagem.

As características do cavalheiro medieval são reconhecidas no índio Peri que é forte, belo, corajoso e ainda um vassalo diante do amor que sente por Cecília - a quem o índio chama por Ceci - vassalagem marcada pela escravidão que sabíamos ser algo incompatível com a cultura indígena. A servidão de Peri diante de Ceci beirava a devoção como "Em Peri o sentimento era um culto, espécie de idolatria” (ALENCAR, 1998, p.51) ou ainda quando,

de repente, entre o dossel de verdura que cobria esta cena, ouviu-se um grito vibrante e uma palavra de língua estranha:

-Iara!

É um vocábulo guarani: significa a senhora. (ALENCAR, 1998, p. 97).

O autor marca bem a diferença do amor dos pretendentes de Cecília por ela, "Ladeano desejava; Álvaro amava; Peri adorava. O aventureiro daria a vida para a gozar; o cavalheiro mostrava a morte para merecer um olhar, o selvagem se mataria, se preciso fosse, só para fazer Cecília sorrir" (ALENCAR, 1998, p.52) o que só reforça a postura servil de Peri diante de sua Ceci. É somente com a conversão ao cristianismo que Peri pode proteger Ceci, 
já que amá-la nunca foi uma escolha possível, afinal como seria possível transpor a relação entre uma mulher branca e um homem indígena? Sem saída, Peri se converte ao cristianismo negando mais uma vez seus valores e agora credos e, assim segue para o momento sacrificial da obra, como podemos observar no trecho a seguir:

- Se tu fosse cristão, Peri!....

O índio voltou-se extremamente admirado daquelas palavras.

- Por quê?... perguntou ele.

- Por quê?... disse lentamente o fidalgo. Porque, se tu fosse cristão, eu te confiaria a salvação de minha Cecília, e estou convencido de que a levarias ao Rio de Janeiro, à minha irmã. (...)

- Sê cristão! Dou-te o meu nome.

Peri beijou a cruz da espada que o fidalgo lhe apresentou, e ergue-se altivo e sobranceiro, pronto a afrontar todos os perigos para salvar sua senhora. (ALENCAR, 1998, p.291)

Dessa forma, somente um cristão - e não um pagão- poderia salvar a jovem Cecília do perigo, mesmo que esse "pagão" fosse alguém de "alma nobre". Nem todas as qualidades do índio Peri o tornariam nobre o suficiente para tal missão, isso só poderia acontecer mediante a conversão ao cristianismo. Metaforicamente podemos concluir que por melhor que seja o aborígene, por mais bon sauvage que ele se apresente, ainda assim precisa negar tudo o que lhe constitui como índio. E nem por isso será digno do amor da jovem branca e descendente do colonizador.

O desfecho romântico de $O$ Guarani não acontece e o romance já nasce na impossibilidade do amor entre Peri e Ceci. A questão é que os romances indianistas de Alencar não conseguem se encaixar plenamente no enredo romântico padrão do século XIX. A primeira obra indianista de Alencar é construída com intenção de formulação mítica, como narrativa fundadora do que podemos contemporaneamente chamar de democracia racial e tem sérios entraves em se realizar porque esbarra no patriarcalismo que impede o romance e a sua consumação entre uma mulher branca e um homem indígena, mesmo que o autor torne a relação possível em Iracema, apesar de ser entre um homem branco e a mulher indígena. Dessa forma, o que constatamos é a impossibilidade de superação diante do contexto social e histórica do escritor de construir uma relação possível entre uma mulher branca - elemento que já traria inferioridade social - e um homem indígena, um selvagem. 
Acima de discussões raciais ou patriarcais, não podemos negar que as obras indianistas debatem, quase que constantemente, o fato de que "o romance indianista procura responder não apenas se o indígena pode tornar-se personagem de romance, mas se pode atingir o nível de humanidade" (GRAÇA, 1998, p.35). Um exemplo disso é o momento da narrativa em que Aires Gomes - escudeiro e amigo de D. Antonio - tenta diminuir a importância do fato do filho de D. Antonio ter matado uma índia,

(...) - confessou que D.Diogo cometeu uma imprudência matando essa índia.

- Dize uma barbaria, uma loucura!... Não penses que com ser meu filho, o desculpo!

- Julguais com demasiada severidade.

- E o devo, porque um fidalgo que mata uma criatura fraca e inofensiva comete uma ação baixa e indigna (...)

- Mas é preciso ver que casta de mulher é esta, uma selvagem... (ALENCAR, 1998, p.36)

Segundo Graça (1998, p.40), O Guarani "é o mito cruel que se esconde sob a placidez do texto romântico: o indígena deve renunciar à sua cultura, à sua religião não para sobreviver, mas para merecer o destino sangrento dos mártires”. Assim, Alencar busca construir em $O$ Guarani o elo entre a cultura do colonizador e a do colonizado. Da família de Cecília, de D. Antonio temos a exaltação da família patriarcal através do senhorio feudal que não nos esqueçamos de que foram essas mesmas famílias que distribuídas em capitanias pela colônia se instalaram em latifúndios, impondo suas crenças, a força do trabalho escravo, servil e sua cultura- e, mesmo nesse contexto, o índio surge na narrativa dotado de atitudes exemplares mesmo que preso no conflito da relação entre os costumes locais e a inoculação dos valores eurocêntricos.

Ao definir Peri, D. Antonio de Mariz, o fidalgo português pai de Cecília, diz que é “um cavalheiro português no corpo de selvagem”. Graça (1998, p.39) nos alerta para o elemento que quase nos escapa despercebido sobre a "expropriação da alma indígena", revelando que:

Quando o nobre opõe português a selvagem, apenas indica o óbvio. Mas quando polariza cavalheiro e corpo trapaceia com seu ouvinte (e Alencar com seu leitor). Corpo na verdade se opõe a alma, a espírito. O índio, para D. Antonio Mariz, portanto, oferece seu vigor físico e sua saúde corporal, à alma portuguesa. 
Dessa forma, o destaque ao caráter na descrição de Peri se dá graças à "alma portuguesa" que se revela no contato com o homem branco e que atinge seu apogeu com a conversão ao cristianismo. Semelhantemente ao que acontece com o Brasil, essa terra selvagem de povos primitivos que é transformada pela boa e construtiva influência do homem branco e cristão. Assim, para Bosi (1974, p. 154),

Tanto nos romances nativistas (O Guarani, Iracema, Ubirajara) como naqueles em que o bom selvagem se desdobra em heróis regionais $(O$ Gaúcho, O Sertanejo), o selo da nobreza é dado pelas forças do sangue que o autor reconhece e respeita igualmente na estirpe dos colonizadores europeus. Ao heroísmo de Peri não deixa de apor a sobranceria de Dom Antônio de Mariz e sua esposa, os castelões impávidos de $O$ Guarani. (sic)

O índio Peri demonstra qualidades e virtudes na sua índole e personalidade melhores que a dos personagens "civilizados" na obra, o que demonstra como a narrativa caminha para a construção de uma legitimação do processo do colonizador, a partir da crença de que, ao ter contato com o homem branco, o índio não só aprende com ele, mas graças a sua inata "bondade" torna-se algo ainda melhor, ou seja, humaniza-se. Se essas legitimações se fizessem bem sucedidas, para o romancista, estaríamos enfim produzindo uma literatura, genuinamente, a partir da justificação impossível do processo violento colonizador que dizimou a quase totalidade da população indígena.

Quando os jesuítas chegaram imbuídos do desejo da catequese eles destruíram o ethos do autóctone porque reuniam crianças indígenas de diferentes grupos tribais e com isso faziam com que elas perdessem sua identidade, já que o que as faziam pertencentes daquele grupo eram as histórias de tradições, costumes e credos que eram passadas, através da oralidade, de geração a geração e que se firmavam como verdade absoluta. A mistura desses povos tribais rompia esse processo. Analogamente, Alencar também destrói a identidade do indígena quando, não só em $O$ Guarani, cria personagens que precisam perder tudo o que os identificam, seus costumes, suas crenças, seu modo de viver para se tornarem material estético possível de um projeto que visava uma literatura própria que se distanciasse da portuguesa, mas que se mantivesse próxima ao que era escrito na Europa.

No entanto, nem mesmo o empenho de Alencar em tornar o indígena próximo e, algumas vezes, superior ao europeu como já foi dito anteriormente, o fez escapar de estampar certa consciência de inferioridade em relação ao colonizador como no trecho em que Peri fala a D. Antonio de Mariz sobre as razões de sua amizade, 
Enquanto falava, um assomo de orgulho selvagem da força e da coragem lhe brilhava nos olhos negros, e dava certa nobreza a seu gesto. Embora ignorante, filho das florestas, era um rei; tinha a realeza da força. Apenas concluiu, a altivez do guerreiro desapareceu; ficou tímido e modesto; já não era mais do que um bárbaro em face de criaturas civilizadas, cuja superioridade de educação o seu instituto reconhecia. (ALENCAR, 1998, p.99-100).

Diante das contradições entre o índio real e o projeto estético do indianismo, assim como o deslocamento que ocorre dentro do texto literário, entre o que o autor gostaria de construir em sua representação e o que ele de fato faz da obra, é que podemos constatar que $O$ Guarani surge na tríade alencariana como um documento importante das contradições e condições históricas do século XIX no Brasil.

É imbuído do desejo de construir uma ideia de nação que Alencar consegue revelar e apreender em seu texto, se não a totalidade, pelo menos a essencialidade dos entraves que se estabeleciam entre a história e o desejo dos seus escritores, problematização que segue nas outras suas duas obras indianistas.

Iracema (1865) também traz em si elementos do bom selvagem quando ela passa a possuir elementos de submissão, uma índia "mansa", ou lida de outra forma, domesticada. Já não se trata de um índio bárbaro como o de Bento Teixeira, ou mesmo do selvagem e bruto dos cronistas. O índio alencariano tem projeção europeia, o que nos faz refletir sobre o papel benéfico da colonização impresso nos textos indianistas de Alencar.

O romance Iracema é ambientado no período da colonização do Ceará, início do século XVII, e de outras regiões do nordeste, esse momento histórico marcado pelo confronto entre os índios potiguaras que habitavam aquela região e o colonizador. Esse é o material histórico que serve como base para que Alencar dê o título de lenda ao seu romance. Em Iracema podemos perceber a construção estética que revela as contradições da relação colonizador e colônia diante da contradição de sentimentos e ações como o amor e o ódio, ou ainda, o amor e a escravidão.

Nessa relação, criada em um mundo inventado pelo autor entre nativo e colonizador, a história se torna mero objeto estético e revela que em Iracema não é o contar da história o que importa, mas sim a criação de um passado grandioso que estabelecesse a nação, mesmo que para isso o índio se apresente descaracterizado e desconectado de sua consciência primitiva. A descrição de Iracema já se revela em seu aspecto mítico e em sua caracterização e existência inteiramente ligada à natureza, sobrepondo-a ao conceito de pátria 
e remetendo-a à paisagem, o que faz com que em determinados momentos um elemento se dissolva no outro, como no trecho:

Iracema, a virgem dos lábios de mel, que tinha os cabelos mais negros que a asa da graúna, e mais longos que seu talhe de palmeira. $O$ favo da jati não era doce como seu sorriso; nem a baunilha recendia no bosque como seu hálito perfumado. Mais rápida que a corça selvagem, a morena virgem corria o sertão e as matas do Ipu, onde campeava sua guerreira tribo, da grande nação tabajara, o pé grácil e nu, mal roçando, alisava apenas a verde pelúcia que vestia a terra com as primeiras águas. (ALENCAR, 1998, p. 17)

E nessa invenção o olhar do criador, no caso o autor, de Iracema ainda é o olhar do outro, na verdade sempre será. É a índia que surge como a europeia deveria ser, debaixo dos preceitos católicos e submissa ao homem branco, é assim que Martin vê Iracema. No encontro dos amantes estão presentes a projeção da mulher-mãe e protetora,

Foi rápido como o olhar, o gesto de Iracema. A flecha embebida no arco partiu, gotas de sangue borbulham na face do desconhecido. De primeiro ímpeto, a mão lesta caiu sobre a cruz da espada; mas logo sorriu. O moço guerreiro aprendeu na religião de sua mãe, onde a mulher é símbolo de ternura e amor. Sofreu mais d'alma do que da ferida. O sentimento que ele pôs nos olhos e no rosto, não o sei eu. Porém a virgem lançou de si o arco e a uiraçaba, e correu para o guerreiro, sentida de mágoa que causara. (ALENCAR, 1998, p. 18)

Ao enxergar Iracema como mulher concebida pelo viés católico europeu, é impossível não lembrarmos de um trecho da carta de Caminha - de 1500, em que ele descreve uma índia e uma das missas realizadas aqui no Brasil:

Entre todos estes que hoje vieram não veio mais que uma mulher, moça, a qual esteve sempre à missa e a quem deram um pano para que se cobrisse, e o puseram em volta dela. Todavia, ao sentar-se, não se lembrava de o estender muito para se cobrir. (CASTRO, 2014, p. 112)

Seguimos, dessa forma, para mais uma representação criada e imposta por romancistas que não conseguem - talvez, nem mesmo pudessem - integrar a comunidade indígena respeitando e reconhecendo seus costumes e crenças como um povo diferenciado, mas não inferior ou carente de conversão religiosa e cultural.

A narrativa também retira do homem branco a culpa, valorizando o guerreiro que assume suas atitudes, pois, "ele não deixará o rastro de desgraça na cabana hospedeira" (ALENCAR,1998, p. 44), e o exime da violação, já que Martin deita-se com Iracema para que nasça Moacir - o primeiro cearense que surge no texto como a óbvia metonímia do brasileiro 
- porque "desce-lhe do céu ao atribulado pensamento uma inspiração" (ALENCAR,1998, p. 46).

Podemos observar a submissão da nativa diante do colonizador no texto de Machado de Assis, Instinto de Nacionalidade (1992), “a índia não resiste, nem indaga: desde que os olhos de Martim se trocaram com os seus, a moça curvou a cabeça àquela doce escravidão" (ASSIS, 1992, p.179), mesmo quando a índia percebeu que Martim estava triste com saudade da noiva ela não hesitou em adentrar a floresta de mãos dadas com o estrangeiro e lhe oferecer uma bebida que foi capaz de "revelar" o desejo de Martim por ela. Nesse momento, surge no texto um impasse no autor diante da configuração da índia Iracema. Se por um lado ela é a índia escrava do amor, submissa na relação com o amante branco, por outro ela parece saber manipular uma situação para se tornar amável e desejável por ele.

Ao afirmar que "a alegria voltará logo à alma do guerreiro branco, porque Iracema quer que ele veja antes da noite a noiva que o espera" (1998b, p.15), nos parece claro que Iracema já havia arquitetado um plano que resultaria em uma cena sensual e reveladora, que naquele momento era desconhecida de Martim, mas não de Iracema. Aliás, o sexo e a violência cometida contra os índios tanto por portugueses quanto por franceses durante a colonização do Ceará - região que se passa o romance - são elementos e informações cortadas ou censuradas dentro da obra de Alencar. Se em $O$ Guarani a vassalagem e servidão de Peri percorre toda a narrativa, em Iracema há um jogo que às vezes revela uma índia que deveria ser escrava na relação com Martim, mas que pode revelar-se como manipuladora da situação como no caso analisado.

Em Iracema também podemos, assim como em $O$ Guarani, encontrar a legitimação do processo de colonização. É possível observar que desde quando Iracema é apresentada temos uma personagem ligada intrinsecamente à natureza, e essa ligação nos revelava a já conhecida sintonia orgânica entre indígena e meio natural. No entanto, ao encontrar Martim, que durante todo o texto precisa ser visto como metáfora da cultura branca e europeia, a índia se distancia da sua cultura e dos seus instintos até chegar ao nível de desculturamento como o que vemos no trecho abaixo, no qual Iracema já não escuta mais o chamar da arara ará,

A ará pousada no jirau alonga para sua senhora os verdes tristes olhos. Desde que o guerreiro branco pisou a terra dos tabajaras, Iracema a esqueceu (...) Se repetia o mavioso nome da senhora, o sorriso de Iracema já não se 
voltava para ela, nem o ouvido parecia escutar a voz da companheira e amiga, que dantes tão suave era ao seu coração. (ALENCAR, 1998b, p.23)

Dessa forma, Alencar segue construindo um personagem indígena que precisa se desprender da sua própria cultura para que, somente, em contato com a cultura branca se torne algo melhor, civilizado, evoluído. O autor segue os jesuítas acreditando que o índio precisa de salvação. Contudo, há uma diferença entre Peri e Iracema, Peri se distancia de sua cultura e seu credo e todo o universo indígena parece na narrativa concordar com suas escolhas, mas em Iracema a natureza se entristece nesse distanciamento como a ará que "triste e muda, desdenhada de sua senhora, não parecia mais a linda jandaia e sim o feio urutau que somente sabe gemer" (ALENCAR,1998, p. 23). Em contrapartida, Martim não se distancia de sua cultura, pelo contrário, demonstra-se saudoso por sua terra, sua noiva, seus parentes e chega a avisar Iracema que irá partir e que ela deve voltar aos braços dos seus e esquecer as mortes provocadas pelo envolvimento deles dois.

Iracema apresenta-se como um texto construído para que não fale por si, ele precisa de intervenções, de "certezas" históricas, etnográficas e até literárias, intromissões na leitura que são feitas através de notas e esclarecimentos e dados pelo autor. A retomada aos textos dos cronistas, dos viajantes e as preocupações em esclarecer a cultura indígena do viés branco europeu direcionam o leitor no texto a compreender o índio retratado.

Como já sabemos as obras alencarianas indianistas preocupavam-se com uma reformulação da imagem do índio em uma relação quase que intrínseca entre o índio e a natureza, no entanto, essa relação construída esbarra na ambiguidade ideológica inerente ao processo de colonização.

No caso de Ubirajara (1874), Alencar constrói um herói indígena anterior à história da nação, portanto um recuo no tempo se o compararmos as outras duas obras indianista, O Guarani e Iracema. Ubirajara, assim como os outros personagens indígenas de Alencar, revelam uma preocupação do autor na construção e caracterização dos personagens. Na autobiografia Como e porque sou romancista (1898), podemos observar, especificamente, no caso do personagem indianista Peri esta preocupação na configuração de seus protagonistas,

N'O Guarani o selvagem é um ideal, que ao escritor intenta poetizar, despindo-o da costa grosseira de que envolveram os cronistas, e arrancando- 
o ao ridículo que sobre ele projetam os restos embrutecidos da quase extinta raça. (ALENCAR, 2000, p.9)

Em Ubirajara, por se tratar do índio antes do contato com o homem branco, Alencar preocupa-se em demasia em desconstruir as imagens negativas relacionadas aos índios feitas pelos cronistas e viajantes, como podemos observar na fala do autor, "Como admitir que bárbaros, quais nos pintaram os indígenas, brutos e canibais, antes feras que homens, fossem suscetíveis desses brios nativos que realçam a dignidade do rei da criação?" (TELES, 1986, p.185). Dessa forma, tentando reverter a imagem construída por esses relatos que tratavam o índio como bárbaro e animal selvagem, Alencar constrói um índio a quem atribui valores do homem branco e europeu.

Alencar ainda classificou esse homem branco que produziu os relatos a respeito do indígena em duas classes de homens,

(...) a dos missionários e a dos aventureiros. Em luta uma com outra, ambas se achavam de acordo nesse ponto, de figurarem os selvagens como feras humanas. Os missionários encareciam assim a importância da sua catequese; os aventureiros buscavam justificar-se da crueldade com que tratavam os índios. (ALENCAR, 1999, p.14-15)

O romancista tenta em seu prólogo esclarecer quais eram os interesses de missionários e aventureiros em retratar o índio daquela forma. No entanto, aqui nos cabe perguntar quais eram os interesses de Alencar em se contrapor a esses relatos?

Pelo menos uma diferença se faz notória entre Ubirajara e as outras duas obras indianistas de Alencar em Iracema e $O$ Guarani a temática era centralizada na questão da gênese do brasileiro e na sua formação. Por isso os protagonistas indígenas são sempre acompanhados do homem ou mulher branca para dar sustento a pauta da miscigenação. Em Ubirajara essa preocupação não existe, pois estamos diante de um tempo mítico, inaugural e fundador.

Em Ubirajara, Jaguarê, filho do líder da tribo Araguaia, procura em outras terras um inimigo para levar como prisioneiro a sua taba e assim, conseguir o título de guerreiro para só então tornar-se Ubirajara. Dessa forma , o índio Jaguarê percorre toda narrativa em um processo de autoconstrução para tornar-se um herói. Mas, para que isso aconteça, é necessário que ele passe de caçador a índio guerreiro. Assim o conflito de Jaguarê nasce entre a natureza e a cultura. Contudo, Jaguarê só atingirá o título de guerreiro com a criação de uma 
nova nação, "As duas nações, dos araguaias e dos tocantins, formaram a grande nação dos Ubirajaras, que tomou o nome do herói” (ALENCAR, 1999, p.52).

Ubirajara se configura como a reflexão sobre o problema da elaboração da nacionalidade brasileira, pois é a palavra literária o que torna possível a constituição da identidade brasileira a todos, assim como é pela palavra que mesmo sendo nobre Jaguarê busca se tornar guerreiro. Analogamente, é possível observar que assim como o índio que mesmo sendo honesto e valente precisa, a partir do combate, trocar de nome para se tornar guerreiro, nossa sociedade recém independente também precisa constituir uma literatura original para se tornar nação.

No entanto, mesmo tendo protagonistas com construções e características distintas, as narrativas apresentam pontos em comum. Como o direcionamento da leitura, como já mencionado. Em Ubirajara também temos um texto que, paralelamente à narrativa, orienta a nossa leitura. No caso, nos referimos ao texto introdutório do romance, o prólogo intitulado Advertência, como o denomina Alencar. Esse texto que nos "adverte" surge como o atestado de verossimilhança do índio mítico na prosa alencariana, ou seja, torna o enredo verídico por ser baseado em relatos não ficcionais da história.

É na figuração do índio, por assim dizer primitivo, anterior ao contato com o colonizador que Alencar tenta, valendo-se das notas e explicações, demonstrar a superioridade da nação recém-formada diante da metrópole. Para isso, justifica com antecedência os costumes indígenas inaceitáveis para o homem branco, como no trecho "não se lembravam, ou não sabiam que eles mesmos provinham de bárbaros e ainda mais ferozes e grosseiros do que os selvagens americanos" (ALENCAR, 1999, p.12). As narrativas paralelas que Alencar constrói em Ubirajara buscam justificar costumes não civilizados dos autóctones registrados nos relatos da Literatura de informação como, por exemplo, as guerras entre tribos e até mesmo a antropofagia, fazendo com que o romance surja como um produto da leitura do autor dos textos dos cronistas.

Os livros escolhidos para constituírem o corpus deste segundo capítulo se ligam e se relacionam dentro do projeto literário e também político de Alencar como material possível de contemplação pelo estrangeiro. A tríade indianista alencariana, pesada a particularidade de cada obra, torna o índio matéria prima de um projeto estético baseado em temas nacionais, mas que não se distanciasse dos padrões estéticos da formação dos grandes centros. 
Dessa forma, cada narrativa indianista de Alencar tentou construir alicerce tanto para formação estética da nossa literatura, como para a constituição ideológica da nação brasileira. Em $O$ Guarani o que temos é muito mais a constituição de uma nação pueril do que a revisitação das ações em um passado, o que revela o desejo do que o autor gostaria de criar. $O$ Guarani é criado em um momento em que as ideias se encontram ainda dispersas sobre como nos enxergávamos e o que desejávamos enquanto nação. Também era o momento inaugural na produção literária de Alencar na contradição entre o índio como inspiração, mas também como ameaça social.

Iracema, por sua vez, é a índia guerreira, aquela que seria copartícipe na gênese do brasileiro, a partir da fusão com o sangue do homem branco. Iracema é a força geradora, de Moacir, do primeiro cearense, dos brasileiros. Ubirajara criado em um tempo anterior a qualquer contato com o homem branco surge como a legitimação do que o aborígene não era um bárbaro como descreveram os cronistas e os viajantes. Afinal de contas, assumir o ponto de vista de assombro e ojeriza, mas também de assombramento, diante dos costumes autóctones, que tiveram os colonizadores quando desembarcaram em suas naus, era o mesmo que confessar o índio como ameaça na constituição do povo e da nação brasileira. Se isso se realizasse não nos restaria nada genuinamente nosso, do ponto de vista dos romancistas, para encabeçar nosso projeto literário e de constituição de nação.

Dessa forma, Ubirajara se apresenta como o índio honesto e corajoso e ainda como o responsável pela continuidade do ethos através de sua descendência, como no trecho, "mais tarde, quando vieram os caramurus, guerreiros do mar, ele campeava ainda nas margens do grande rio" (ALENCAR, 1999, p.110). Alencar não só cria um tempo literário anterior ao contato com o colonizador, como também parece ignorar por completo que mesmo uma "grande nação" como a dos Ubirajaras não resistiria ao violento e sangrento processo de colonização a que submeteram os portugueses os índios que aqui viviam.

Compreendemos, portanto, a Literatura Brasileira como a formulação tanto estética como histórica do processo social brasileiro. Dessa forma, sabemos que é a partir do Romantismo, no século XIX, diante da necessidade imposta de narrar a formação da nação brasileira que nossos escritores de alguma forma precisaram lidar com problemas históricos e sociais. Em seu processo criativo, José de Alencar precisou encarar com questões que eram reais, mas que até então eram impensáveis como nosso período colonial, a miscigenação, o 
genocídio dos índios e tantas outras, e tratou delas como seu contexto social, cultural e de escritor permitiram.

No próximo capítulo observaremos como muitas dessas questões também estão presentes em Quarup, de Antonio Callado. No entanto, acreditamos que encontraremos outras respostas de formas diversas para essas questões. Na narrativa de Callado analisaremos como o autor segue uma tradição que tenta ainda entender quem são os brasileiros, qual o nosso passado e como é o Brasil. 


\section{CAPÍTULO 3}

\section{ANTONIO CALLADO: HERDEIRO DA TRADIÇÃO EMPENHADA}

Neste capítulo trataremos de apresentar e discutir a trajetória literária de Antonio Callado considerando a noção de empenho, desenvolvida por Antonio Candido (2009), levantando e analisando aspectos do contexto social e literário do Brasil do século XX, bem como algumas de suas experiências sociais e profissionais. Não procuramos estabelecer uma ligação simplista e mecânica, e deformada entre a vida de Antonio Callado e suas produções literárias. Ao desenvolvermos este capítulo nos preocuparemos em observar algumas influências de Callado que cumpriram algum papel na construção de suas obras, especificamente Quarup (1967), como parte de um projeto que tinha como intenção a desalienação e formação da consciência crítica de seus leitores diante das injustiças do país.

No capítulo anterior buscamos compreender as questões pertinentes aos escritores românticos do século XIX, que incluíam: o passado colonial e suas contradições, elaboração estética do índio e os problemas sociais e políticos daquele momento. Neste capítulo também será necessário situar os acontecimentos históricos, principalmente, dos anos de elaboração e publicação de Quarup que foram marcados pelo pessimismo, a desesperança e o sentimento de impotência provocados pela ditadura militar. Essa correlação entre a trajetória de vida de Callado e o contexto histórico tem como objetivo revelar problematizações próprias do escritor e do seu momento, já que, para Antonio Candido (2009, p. 31),

O ponto de vista histórico é um dos modos legítimos de estudar literatura, pressupondo que as obras se articulam no tempo, de modo a se poder discernir uma certa determinação na maneira por que são produzidas e incorporadas ao patrimônio de uma civilização.

Antonio Carlos Callado nasceu em 26 de janeiro de 1917 na cidade de Niterói, que naquela época era a capital do estado do Rio de Janeiro. Callado foi o quarto, último e único filho homem da professora Edite Pitanga e do médico Dario Callado. A família de Callado era de classe média alta, mas os negócios e patrimônios da família não resistiram à doença do pai de Callado, que sofria de tuberculose.

Sérgio Miceli em seu livro Intelectuais à Brasileira (2001) fala sobre a carreira de escritor nas décadas de 30 e 40. Para o autor, essa carreira surge como uma alternativa de ascensão social para os filhos de uma classe que foi dominante, mas que agora se viam em 
decadência econômica que ocorria na maioria das vezes, pela perda paterna, como aconteceu na família de Callado.

Sobre as dificuldades financeiras após a morte do pai e o apego à casa em que passou sua infância, Callado responde em entrevista,

Há pouco tempo eu fui a Niterói, onde eu nasci, em 1917, fui especialmente porque eu soube que a casa onde eu passei os primeiros anos da minha infância, uma rua pertinho da praia de Icaraí, ia ser demolida. É uma casa grande; meu pai era médico e tinha um lugar para atender em casa; minhas tias tinham um colégio até, em baixo, durante um tempo [...] Depois passei um tempo em Petrópolis e um tempo em Teresópolis. Papai adoeceu tuberculose pulmonar - e, coitado, naquela época a recomendação era o clima [...] Então morei nessas duas cidades; daí também o meu apego a Petrópolis, de que eu gosto muito. Então, passou-se aí minha infância, nessas boas casas de Icaraí e, depois, em casas muito menos boas, porque meu pai, com a doença, gastou muito dinheiro, e a nossa vida ficou assim mais restrita. Aí, já no Rio, depois que minha mãe enviuvou, as casas vão ficando menos importantes, para a vida da gente. (CALLADO apud LEITE, 1982, p.249)

É, contudo, em outra casa que ele diz ter nascido sua determinação para escrever, "Uma outra casa, da rua Passos de Pátria, foi aquela onde (eu me lembro perfeitamente) nasceu a minha determinação de escrever”.(CALLADO apud LEITE, 1982, p. 3)

O pai de Callado possuía uma vasta biblioteca, o que tornou possível que o escritor se apropriasse da cultura literária, sobretudo da francesa, mesmo que naquela época já se iniciava a influência do imperialismo norte-americano, "Meu pai tinha lá uma biblioteca bastante boa de literatura, brasileira e francesa. Eu me lembro dos livros que li, de poesia, e das primeiras tentativas de ler em francês, que aprendi por minha conta" (CALLADO apud LEITE, 1982, p.3). Além de médico, o pai de Callado era poeta parnasiano e admirador de Bilac. Percebemos, portanto, que Callado viveu em um ambiente que lhe proporcionou o apego às letras. Ao ser perguntado em entrevista sobre se a família incentivava sua escrita, ele responde:

Nem tanto. O que havia era um ambiente muito literário em casa. Por exemplo, eu me lembro muito e com muita afeição do meu avô materno que, infelizmente, morreu na gripe espanhola, quando eu tinha uns dois anos. Ele era do Instituto Histórico e Geográfico e gostava muito de índio, de estudar esse assunto. Tem até dois trabalhos sobre isso: O Selvagem Perante o Direito e A Pena de Açoites. Então, o negócio de índio é uma espécie de parte da minha infância, também. (CALLADO apud LEITE, 1982b, p. 4)

Como influências familiares na obra de Callado, podemos destacar: a determinação de escrever, ler e a religiosidade. Callado reconhece em entrevista como foi 
importante em sua família e para sua formação a religião. Mas, ressalta que "é difícil comunicar isso às pessoas hoje, porque mudou tanto e tão bruscamente...Ainda há aulas de catecismo, por exemplo, mas naquele tempo era uma questão de intensidade" (CALLADO apud LEITE, 1982b, p.4). Certamente, esse intenso ensino religioso proporcionou a Callado a possibilidade de criar vários personagens religiosos como, por exemplo, o padre Nando, Fontoura, os irmãos Villas Boas, padre Paiva e outros. Callado chega a comparar sua formação religiosa com a do Padre Nando, como no trecho abaixo,

A gente está em todos os personagens. É claro que, no caso de Nando, havia uma identidade quase que de geração, da minha geração, em relação a de Nando. Apenas, no caso dele fica tudo ainda gravado porque ele era padre. Mas o tipo de educação, o tipo de treino religioso era muito semelhante. (CALLADO apud LEITE, 1982a, p.237)

Em A Estética da Criação Verbal (2011, p.20) Bakhtin afirma que,

Quando a personagem e o autor coincidem ou estão lado a lado diante de um valor comum ou frente a frente como inimigos, termina o acontecimento estético e começa o acontecimento ético que o substitui (o panfleto, o manifesto, o discurso acusatório, o discurso laudatório e de agradecimento, o insulto, a confissão-relatório, etc).

Para Bahktin, (2011, p. 11-13), é necessário reconhecer o caráter de “consciência criadora" do autor uma vez que,

a consciência da personagem, seu sentimento e seu desejo de mundo diretriz-volitivo-emocional concreta - , é abrangida de todos os lados, como em um círculo, pela consciência concludente do autor a respeito dele e do seu mundo.

Por outro lado, quando personagem e autor coincidem é necessário que o autor se coloque,

à margem de si, vivenciar a si mesmo não no plano em que efetivamente vivenciamos a nossa vida; só sob essa condição ele pode completar a si mesmo, até atingir o todo, com valores que a partir da própria vida são transgredientes a ela e lhe dão acabamento. (BAHKTIN, 2011, p. 11-13)

Neste capítulo e, principalmente, no próximo veremos que em alguns momentos os personagens de Callado estão "lado a lado" diante de seus posicionamentos, revelando críticas ou ainda suporte ideológico. Sabemos que Quarup, por definição de Callado, é "um livro engajado em vários sentidos" (CALLADO apud LEITE, 1982b, p.6). Todavia, se nesse capítulo buscaremos aproximações entre as práticas jornalísticas de Callado e sua produção literária, no próximo capítulo - de análise de fato da obra Quarup - nos deteremos a compreender como esta obra não é engajada em seu sentido depreciativo. 
Como vimos, Antonio Callado e sua família passaram por algumas privações financeiras após a morte de seu pai. Devido às circunstâncias, Callado começa a trabalhar em uma firma comercial para custear seus estudos, mas logo em seguida, precisamente em 1937 ano em que Getúlio Vargas instala o Estado Novo - inicia sua carreira jornalística,

Em 1937, aos vinte anos, iniciei minha carreira jornalística no Correio da Manhã. Apresentei-me a Paulo Bittencourt, parente distatnte, com uma carta de recomendação. Lida a carta, depois de ter sido avisado de que a questão de parentesco nada significaria do jornal, fui encarregado, de fazer uma reportagem, como experiência. Algo sobre Niterói. Esmerei-me no trabalho, mas quando mostrei ao diretor, vi que fizera uma crônica em vez de uma reportagem. Mas, como estava bem escrito, deram-me nova oportunidade. Dessa vez acertei e fui empregado. (CALLADO apud LEITE, 1982b, p.5)

O ano de 1937, que Callado inicia suas atividades como jornalista também é o ano marcado, como dito anteriormente, pela instalação do Estado Novo ${ }^{12}$ através do golpe do mesmo ano que foi primordial para que Getúlio Vargas se mantivesse no poder com poderes totais. Interessa-nos ressaltar que o Estado Novo estabelece uma nova Constituição para o país, que por sua vez garante que Getúlio Vargas governasse sem limites de mandato. No entanto, esse golpe só foi possível graças a uma falsa estratégia elaborada pelo capitão Olímpio Mourão Filho - o mesmo que seria o articulador iniciador do Golpe de 64.

Essa estratégia foi chamada de Plano Cohen e consistia na falsa divulgação de que havia um projeto elaborado por comunistas para assumirem o Brasil. Dessa forma, como o comunismo não era aceito na sociedade brasileira, Vargas se valeu disso e aproveitou para decretar o Estado de Sítio no Brasil, e com isso conseguiu restringir muitos direitos da população, além da concentração de poderes que durante sua vigência aproximou o Estado democrático do autoritarismo.

Mesmo exercendo o jornalismo neste período conflitante e extremamente decisivo para história e política brasileira, Callado, se forma em Direito em 1939, ainda que nunca tenha exercido a profissão. No jornalismo, desde aquela época e até a Guerra Fria, as discussões e debates giravam em torno do mundo estar dividido entre duas possibilidades, dois projetos de desenvolvimento para humanidade. Este foi um momento de grande importância para o rádio, que se afirmava como uma ferramenta de divulgação ideológica tanto dos países aliados quanto dos países do Eixo. E foi assim, que a rádio BBC (British Broadcasting Corporation) expandiu suas transmissões para vários países e, assim, teve que

\footnotetext{
12 Disponível em: http://www.centrocelsofurtado.org.br/arquivos/image/201211061122440.VARGASRepVelhaANPEC.pdf > Acessado em 14, de outubro de 2015.
} 
contratar jornalistas desses países para trabalharem em Londres. Callado, portanto, é um dos jornalistas que se mudam para Londres para trabalhar na BBC. Aos vinte e quatro anos, Callado, se torna redator roteirista do serviço brasileiro, atuando entre os anos de 1941 e 1942.

Antes de retornar ao Brasil, Callado, se muda para Paris para trabalhar na Radio Diffusion Française. Somente em 1947 Callado retorna ao Brasil com um desejo de redescobrir seu país, atividade que mais tarde seria exercida através do jornalismo e da literatura. Em entrevista, Callado esclarece como se sentia em Londres em relação ao Brasil,

De repente, começou a bater aquela saudade do Brasil. Tão grande...e assumiu várias formas, uma das quais era ir a uma rua, onde tinha os sebos todos, sebos gigantescos, e catar tudo que encontrasse sobre o Brasil, livros brasileiros e portugueses. (...) Voltando, então, logo que eu pude dei um jeito como jornalista, de viajar pelo Brasil. Fui ao Xingu, conhecer os índios, e me deu uma paixão pelo Brasil, e um desejo de ver essas coisas que o brasileiro raramente vê. (CALLADO apud LEITE, 1982a, p. 235)

Na voz do personagem Nando, em Quarup (1967), vemos reafirmado o desejo de Callado de redescobrir o Brasil viajando e conhecendo suas "entranhas",

Acho que para se pegar o espírito do Brasil e as raízes de sua vocação no mundo o roteiro seria outro. Pouquíssimos brasileiros o fazem e daí a confusão em que vivemos. Eu considero a ida ao centro do Brasil, onde vivem os índios em estado selvagem, mais importante, muito mais importante do que conhecer o Rio ou São Paulo. (CALLADO, 1984, p.19)

Callado é um dos escritores brasileiros mais importantes de seu tempo porque foi capaz de resistir ao silenciamento da ditadura para dedicar-se a pensar o sentido histórico de sua época e elaborar novos projetos utópicos. Para compreendermos a relevância do papel de Callado, como escritor no período da ditadura, acreditamos ser necessário uma retomada do contexto histórico da época através de uma breve explicitação.

Quarup foi publicado em 1967, mas o período da narrativa acontece entre os anos de 1950 e 1964, anos que antecedem, portanto, o golpe militar. Anos, portanto de grande 
tensão política e de decisões que determinaram os rumos do país, neste sentido, segundo o Relatório da Comissão Nacional da $\operatorname{Verdade}^{13}$ (2015, p. 82),

Entre 1946 e 1964, o Brasil viveu um período de democracia frágil, instável, hesitante. Democracia é sempre melhor do que ditadura. Os anos entre 1946 a 1964 foram, certamente, bem melhores do que os da ditadura que os sucederam. Esses anos carregam, entretanto, o peso de uma polícia política gestada pelo Estado Novo - deformada pela crença de que os que detêm o poder tudo podem e por práticas violentas que absorveram o pior de nossa tradição escravocrata e das lições de agentes da repressão estrangeiros, especialmente da Central Intelligence Agency [Agência Central de Inteligência] (CIA).

Essa incerteza que pairava no cenário político brasileiro foi tomando a forma da ditadura militar através de uma sequência de acontecimentos e articulações que, de forma reduzida, tentaremos expor para melhor compreensão do contexto histórico que precede o tempo narrativo de Quarup. A renúncia de Jânio Quadros, no início dos anos 60, trouxe para o cenário político uma situação de deterioração institucional agravado pela tentativa de golpe contra a posse do vice, João Goulart, além da imposição do parlamentarismo. O governo de João Goulart trazia uma base nacionalista e grande aproximação com setores populares o que, obviamente, desagradava os setores dominantes. Com isso, os Estados Unidos temendo que o Brasil se aproximasse da revolução Cubana passou a financiar essas camadas descontentes, mas foi com a regulamentação da Lei de Remessa de Lucros - que limitava a saída dos ganhos das multinacionais que atuavam no Brasil - que a crise se instalou. A partir disso, a direita passou a acusar o governo de declarar guerra contra a iniciativa privada e de instalar o comunismo, assim após forte tensão e um trabalho de sabotagem política e ideológica liderado pela direita, com o apoio dos Estados Unidos, é deflagrado em 31 de março de 1964 o golpe de Estado que deu início a longos 21 anos de ditadura militar ${ }^{14}$.

Neste cenário, Callado escreve suas obras, mas mesmo tendo que lidar com o silenciamento imposto pela ditadura, abordou questões que se configuraram no impasse entre a desesperança e a negatividade, mas acima de tudo na impossibilidade das incertezas políticas e ideológicas.

No capítulo anterior, em que tratamos do indianismo, elencamos um elemento indispensável para a formação do sistema literário brasileiro que é o conceito de empenho desenvolvido por Antonio Candido na Formação da Literatura Brasileira - da literatura na

\footnotetext{
${ }^{13}$ Disponível em: < http://www.cnv.gov.br/index.php?option=com content\&view=article\&id=571 > Acessado em 28 de outubro de 2015.

${ }^{14}$ Disponível em: < http://www.acervoditadura.rs.gov.br/contextoh.htm > Acessado em 30 de outubro de 2015.
} 
construção da nação. Assim, para Candido (2009, p. 19- 20), empenho não implica que a literatura seja "social, nem que deseje tomar partido", "Mas apenas que é toda voltada, no intuito dos escritores ou na opinião dos críticos, para a construção duma cultura válida no país. Quem escreve contribui e se inscreve num processo histórico de elaboração do país”. Há, portanto, dois aspectos que se apresentam quando o "empenho" se dá esteticamente, por um lado o descritivismo exótico, nacionalismo e a caracterização estereotipada dos personagens, e por outro lado a possibilidade de revelação das contradições da sociedade brasileira.

Neste sentido, acreditamos que Callado, diante do conceito de empenho de Candido e do exposto até aqui sobre o autor, é um escritor diante do cenário da ditadura militar que parece figurar a relação dialética entre o empenho e o engajamento. Através da temática desenvolvida em sua produção literária, podemos considerar que Antonio Callado se mostrou um escritor consciente de que sua produção poderia colaborar para educar a consciência política do povo brasileiro. Por isso, nos parece que suas obras constituíam o desejo do autor de dar conta da história do país, como um desejo latente de compreender o Brasil. Assim, sua produção literária revela um desejo de interpretação e de reelaboração da história, em modo de uma continuidade, uma vez que uma obra sempre se remete ao contexto histórico obra anterior. Para entendermos melhor temos Quarup (1967) com a consolidação das Ligas Camponesas, em seguida, Bar Don Juan (1971) resgatando os momentos que precedem a declaração da Anistia , Reflexos de Baile (1976) e a decadência e frustração do imaginário utópico comunista, e, por fim, Sempreviva (1980) com a violência e o silenciamento devastador dos tempos da ditadura militar.

Em relação aos índios, em Quarup, temos um romance que ao optar por fazer a questão indígena ser o fio condutor de tanto outros problemas do país se liga de forma direta à tradição romântica que buscamos explicitar no capítulo anterior. No entanto, o índio de Quarup não é, de forma alguma, o índio herói, nobre e mitificado de José de Alencar, pois já não é mais possível ignorar o efeito do processo colonizador sobre esses povos, além do cenário capitalista e suas implicações como, por exemplo, o interesse dos seringueiros e a questão dos latifúndios.

Candido (2009) esclarece, que tanto a literatura brasileira quanto a dos outros países latino-americanos,

é marcada por este compromisso com a vida nacional no seu conjunto, circunstância que inexiste nas literaturas dos países de velha cultura. Nelas, os vínculos neste sentido são os que prendem necessariamente as produções 
do espírito ao conjunto das produções culturais; mas não a consciência, ou a intenção, de estar fazendo um pouco da nação ao fazer a literatura. (CANDIDO, 2009, p.20)

Nesse sentido podemos dizer que a obra de Callado se configura como uma atualização tardia dessa "síndrome" da literatura brasileira de buscar dá conta do país e de compreendê-lo através da escrita. Sartre (2004), em seu ensaio intitulado Que é a literatura? argumenta a respeito da relação do autor perante o grupo social que o lê. Para o autor, a burguesia é um grupo social que está presente na produção da obra e no consumo dela, o que faz com que seja uma necessidade o autor estar ligado estreitamente ao seu momento social, dessa forma,

como as liberdades do autor e do leitor se procuram e se afetam através de um mundo, pode-se dizer igualmente que a escolha que o autor faz de determinado aspecto do mundo é decisiva na escolha do leitor, e, reciprocamente, que é escolhendo o seu leitor que o escritor decide qual é o seu tema. (SARTRE, 2004, p. 58)

Contudo, não é certo que todos os autores de uma época estejam ligados de forma efetiva ao seu momento histórico ao ponto de serem capazes de construir obras literárias que promovam a consciência de uma situação política, ainda que a obra literária se destine a um público específico. No entanto, tanto a declaração do pronunciamento do escritor quanto seu silêncio revelam sua ação e influência. Em contrapartida, ao posicionamento de Sartre sobre a relação entre autor e o grupo que o lê, temos situações específicas como em casos de ditaduras como a que o Brasil viveu.

Tânia Pelligrini (2014) ressalta um aspecto importante para este trabalho que é a situação das produções intelectuais e culturais no Brasil antes do Ato Institucional $\mathrm{n}^{\circ} 5$, em 1968. Então, antes desse marco,

literatura, teatro, música, cinema e educação buscavam "conscientizar o povo", estabelecendo um circuito coletivo de comunicação e de troca de experiências que, se por um lado acreditava serem os intelectuais e artistas os faróis do povo, por outro, a despeito disso, estabelecia mediações e constituía uma promessa de socialização da cultura e de modernização em termos democráticos (PELLIGRINI, 2014, p. 170).

E, assim, os anos que se seguiram ao A5 foram marcados pelos esforços sem medida do governo de cercear as produções culturais de esquerda. Neste sentido, sabemos que as produções que eram liberadas ou eram aquelas que conseguiam disfarçar de forma heroica seu conteúdo esquerdista, ou ainda seriam aquelas consideradas "neutras" e que já não se ligavam aos interesses e necessidades da sociedade naquele momento. 
Ainda no ensaio de Sartre (2004), citado anteriormente, o autor escreve sobre "O que é, por que e para quem escrever?” e esclarece o que é um escritor engajado. Para Sartre, o engajamento e empenho do autor é mediação, no sentido que, um conjunto de atitudes se convertem em obras literárias, uma vez que tudo que não é literário se transfigura em literário. Dessa forma, essas atitudes se apresentam numa clara posição política que na obra literária surge como veículo para o debate sócio-político. Assim, o conceito formulado por Benoît Denis também pode ser aplicado ao escritor brasileiro,

o escritor engajado é aquele que se assumiu, explicitamente, uma série de compromissos com relação à coletividade, que se ligou de alguma forma a ela por uma promessa e que joga nessa partida a sua credibilidade e sua reputação. (DENIS, 2002, p.31)

As obras literárias de Callado - especificamente, Quarup, Bar Don Juan, Reflexos de Baile e Expedição Montaigne, colaboraram para uma construção da memória histórica da esquerda propondo uma forma de repensar o projeto político que era pensado por ela para o Brasil. Ainda que se posicione claramente como um autor engajado, sua produção literária, principalmente Quarup, possuía uma crítica ao engajamento da esquerda. Sem jamais ter se aliado a nenhum partido, Callado, segundo Martinelli (2006, p. 76),tinha "posições políticas liberais - críticas tanto à esquerda quanto à direita - compatíveis com sua posição de editor ou redator dos grandes órgãos de imprensa burguesa"

Martinelli esclarece ainda que,

Nos anos 50 e 60, ser de esquerda era, antes de mais nada, se opor aos aspectos arcaicos da sociedade identificados no latifundiário, propagando a reforma agrária. Com este ideário se identificavam setores da burguesia nacional, militares progressistas, católicos e padres de esquerda, intelectuais comunistas e socialistas, estudantes e vanguardas operárias, inclusive a maior força política das esquerdas da época, o PCB. (MARTINELLI, 2006, p. 77)

A aproximação de Callado com a esquerda e seu efetivo engajamento não necessariamente o aproximaram de um partido político, ou ainda do comunismo. Callado dizia acreditar no socialismo e mesmo sem nunca filiar-se a nenhum partido político estava sempre ligado a movimentos que buscavam transformações sociais. Em entrevista, o autor revela,

(...) Não acho que seja absolutamente obrigatório o autor fazer uma obra de cunho político. O que me choca é a tendência crescente de nossos grupos intelectuais se alienarem da vida do país. Quanto a mim, ainda que pudesse ou sentisse possibilidade de fazer uma obra literária inteiramente abstrata, 
jamais conseguiria ir contra minha natureza: preciso, sempre, exprimir alguma coisa. (CALLADO apud COELHO, 1976, p. 3)

Callado também tinha suas críticas ao comunismo e ao marxismo. Em sua leitura do marxismo criticava o determinismo econômico e o encarava como dogma. Além do marxismo, se posicionava contra as esquerdas de uma forma geral, ou porque lhes cobrava ação ou condenava suas atitudes impensadas. Para Callado, o projeto utópico comunista foi fracassado, como expõe seu ponto de vista em entrevista, além de uma certa desesperança em novos projetos utópicos,

A menos que acontecesse, como ainda pode acontecer, uma coisa muito
inesperada... porque aquela esperança de transformações, a partir das greves,
dos movimentos estudantis... essa caiu. E, para começar o quê? Uma
tremenda revolta popular, a partir da fila do feijão, ou coisa parecida? É
muito difícil imaginar, porque o Exército Brasileiro é muito bem organizado,
o seu poderio de ataque e repressão é uma tremenda arma...de modo que
custa a ver como o país vai sair desse atoleiro que se meteu. (CALLADO
apud LEITE, 1982, p. 236)

Neste ponto do trabalho, diante da defesa de engajamento de Callado na situação política do país, acreditamos ser necessária uma nota para um suposto apoio de Callado ao golpe militar que destituiu João Goulart e deu início aos anos de ditadura no Brasil. Especificamente, sobre a frase dita por Callado "O triste, no episódio tão pífio e latrinoamericano da deposição de Jango, é que realmente não se pode desejar que as Forças Armadas não o traíssem"15. Idos de Março - nome emprestado de Shakeaspare - foi um livro de contos organizado pelo escritor e jornalista Luiz Ruffato que buscava ilustrar o peso do "chumbo" daqueles anos e o clima trágico. Antonio Callado teria dito sobre Joao Goulart, “e quando, eventualmente, chegar à Presidência da República um homem de esquerda, Jango talvez reapareça. Como vice"16. Entretanto, Ana Arruda Callado, repórter e viúva de Antonio Callado, em defesa do escritor esclarece que "acho muito severo com o João Goulart. Se a gente ler direito, os pecados do João Goulart eram muitos também. Mas, evidentemente, que apontar pecados do João Goulart não significa querer uma ditadura militar. Longíssimo disso." 17

\footnotetext{
15 Disponível em < http://www.correiodopovo.com.br/blogs/juremirmachado/?p=5720 > Acessado em 2 de novembro de 2015.

${ }^{16}$ Disponível em < http://observatoriodaimprensa.com.br/marcha-do-tempo/o_golpe passo_a_passo/ $>$ Acessado em 2 de novembro de 2015.

${ }^{17}$ Esse trecho da fala de Ana Arruda Callado teria sido dito em um programa que marcava os 50 anos do golpe de 1964, exibido pela TV Brasil em uma série intitulada "Chumbo Quente". Disponível em < http://observatoriodaimprensa.com.br/marcha-do-tempo/o_golpe_passo_a_passo/ > Acessado em 2 de novembro de 2015.
} 
A nós, diante do que pesquisamos sobre Callado e sua trajetória social, sua produção literária e sobre tal comentário tão infeliz, acreditamos que diante das circunstâncias políticas o escritor ao não ver saída, talvez, tenha visto o golpe como uma saída. Mas, o certo é que até os intelectuais possuem direito ao equívoco e sabemos que nos anos e nas produções que se seguiram Callado foi um combatente ferrenho da ditadura militar e das atrocidades cometidas em defesa da sua manutenção no poder.

Em Quarup, Padre Nando se posiciona contra o regime comunista, revelando a crítica de Callado que acusava os comunistas de abandonarem os povos indígenas. Dessa forma, o personagem comunista Otávio é descrente de lutas especificas e localizadas - como as lutas indígenas - para Otávio, esses problemas e outros da sociedade só seriam resolvidos a partir de uma revolução comunista que mudaria todas as estruturas de todos os segmentos da sociedade. Como no trecho,

Depois de outro silêncio Olavo falou:

- Só mesmo uma revolução.

- Já tivemos quantas?

- Ou a Revolução, como diz Otávio.

A palavra subiu nas trevas oca e sem peso como uma bolha.

- O que é que a revolução adiantaria aos índios? Disse Nando.

- Ah, aos índios nada neste mundo adiantaria - disse Olavo, o Fontoura neste ponto está com a razão. (CALLADO, 1984, p. 164)

Nas primeiras páginas de Quarup, quando Nando é questionado por Leslie e Winifred sobre o "caminho para se formar uma ideia deste gigante país" (1984, p.21), ele explica o que chama de República comunista cristã. Nando explica com entusiasmo como os jesuítas criaram com os índios uma República teocrática e comunista. Assim, para Nando os cristãos antecederam no Brasil e na América do Sul as teorias marxistas,

Espanha e Portugal destroem a fulgurante República Guarani. A ideia comunista, fundamental no homem, é torcida e recriada no século seguinte pelo Manifesto Comunista. Para sempre a igreja perde a primazia" (CALLADO, 1984, p. 20)

Callado, a respeito do seu papel como escritor e sobre o projeto que diz ter desenvolvido com suas obras literárias, revela que,

(...) Quarup, o Bar Don Juan e, sobretudo o Reflexos de Baile (...) esse conjunto é que dá o meu projeto de escritor, que é evidentemente parte da 
minha vida. Como você já viu, meus livros todos têm essa marca da realidade brasileira. Não são livros desligados nem do meio geográfico nem do Brasil político e social. Então, o meu projeto de escritor está, digamos, nesse ponto. (CHIAPPINI, 1982, p. 235-236)

Em entrevista a Lígia Chiappini, Antonio Callado fala sobre o que ele acreditava ser o papel do intelectual naquele momento,

Em todos os campos, artes, literatura, jornal, as pessoas estão começando a achar que o Brasil não pode continuar como está. Então aí me daria a esperança de que o intelectual, mais especificamente, o homem que escreve, portanto, que pensa...supõe-se não? Quem escreve, pensa. Que essas pessoas dessem uma contribuição muito maior. Porque o Brasil precisa de gente. A verdade é essa. (CALLADO apud LEITE 1982a, p. 259)

Dessa forma, seja como jornalista ou literato Antonio Callado não se eximiu de seu compromisso com a nação e por isso fez da linguagem um instrumento de luta e resistência de seus ideais, já que para ele "um intelectual, sobretudo num país como o Brasil, não tem o direito de se eximir como pessoa, e como intelectual, de opinar sobre a situação do país”. (CALLADO apud LEITE, 1982a, p.152)

Através dos textos jornalísticos e as entrevistas concedidas pelo o autor o que fica claro é o seu compromisso com a conscientização nacional que resultasse na modificação da realidade brasileira, ainda que se demonstrasse um escritor ligado à tradição da literatura empenhada, dessa forma, para o escritor, Quarup é "a transformação em ficção, em romance da história recente do Brasil, a história do Brasil, a história contemporânea que nós estamos vivendo agora no país.” (CALLADO apud LEITE, 1982a, p. 68)

Se desde a infância, através do avô, o escritor já demonstrava um interesse pelos índios, quando retorna ao Brasil, após o período no exterior como correspondente, Callado cria então, uma relação intensa e estreita entre o jornalismo e sua produção literária. Em 1947, Callado faria sua primeira viagem à Amazônia e em 1952 receberia o convite de Assis Chateubriand para uma expedição pela selva amazônica à procura do coronel Fawcett que se perdeu na floresta. Esta expedição resultaria no livro-reportagem $O$ esqueleto da lagoa verde (1953).

Segundo Callado, em O esqueleto da lagoa verde, o coronel Percy Harrisson Fawcet teria se aventurado em 1925, pelo interior do Brasil, em busca de uma cidade perdida no sertão. Essa não teria sido a primeira expedição do coronel em busca da tal cidade, mas, infelizmente, foi a última, pois nesta viagem ele e seus companheiros teriam desaparecido na mata. Após vinte e sete anos, portanto em 1952, Callado segue em expedição organizada 
pelos Diários Associados de Francisco de Assis Chateubriand Bandeira de Melo até o Xingu. Na expedição estavam, além de Callado e Chateubriand, o sertanista Orlando Villas Boas e o filho do coronel, Brain Fawcet. Sem dúvida, essa viagem serviu de matriz experiencial para a construção narrativa que marcaria a produção literária de Antonio Callado. Para Arrigucchi Jr. (2001, p.114), Esqueleto na lagoa verde possui um "nítido corte ficcional”, que supera o texto jornalístico e avança no terreno do imaginário como uma "reportagem paradoxal, pois tem seu objeto ausente, como se tratasse de uma busca cujo foco de interesse vai além do factual, do imediato".

O esqueleto da lagoa verde é, assim, considerado o ponto de partida para a criação do romance Quarup (1967), como afirma o próprio autor em entrevista,

Quarup é fruto de um contato de um contato jornalístico que eu pude fazer por conta própria (...) quando resolvi conhecer os índios selvagens. Fiz uma série de reportagens e a impressão que aquilo me causou foi tão forte, tão profunda, que guardei esse material para elaborar um romance depois. (CALLADO apud LEITE, 1982, p.2)

Vale ressaltar que, além de Quarup (1967), o livro Expedição Montaigne (1982) e a peça teatral Frankel (1956) se valem, em sua construção, de informações colhidas pelo autor nos postos do Serviço de Proteção aos Índios durante as viagens feitas à Amazônia entre 1947 e $1952^{18}$. Ao retomar o tema indígena em seu romance, Antonio Callado integra-se na construção de uma narrativa ainda incompleta sobre índios e brancos, sobre o povo brasileiro, mas, principalmente, sobre nossa história e sobre a formação da nossa literatura.

Ao analisarmos a construção de Quarup podemos perceber aproximações bastantes significativas entre história e ficção -entre o jornalístico e literário- se considerarmos que personagens reais estão na narrativa de Callado possuindo o mesmo nome. Como é o caso do índio Anta, que está presente em Quarup e em O esqueleto da lagoa verde. Considerando que $O$ esqueleto da lagoa verde é um relato de reportagem dos dias vividos na expedição em busca do coronel Fawcett, podemos crer que o Anta descrito nesta obra serviu de livre inspiração para o Anta personagem de Quarup. Observemos a descrição de Anta em Quarup,

- Tem machado, Olavo? - perguntou um rapagão de penas de arara nas orelhas, joelheira e braçadeiras nas pernas.

\footnotetext{
${ }^{18}$ Segundo Marcos Martinelli (2006, p. 56), a primeira viagem à Amazônia de Callado teria sido em 1947 "percorrendo o rio Amazonas de Belém a Manaus em uma gaiola". E em 1952 teria acompanhado a expedição em busca do coronel Fawcett.
} 
- Machado pra que, seu Anta sacripanta? - disse Olavo. - Tu não trabalha mesmo. Já botou tua noiva para Matsune pra trabalhar?

- Matsune faz beiju. (...) - Anta vai trabalhar com o machado de Olavo.

- Não vai não porque Olavo não vai te dar coisa nenhuma gigolô das selvas. Esse Anta - disse Olavo a Nando - é o único que fala português melhor que o Canato. Vive assim como está vendo. Penas nas orelhas, miçanga na cintura, braçadeira e joelheira, como se todo dia fosse dia de festa. Toca umas gaitinhas de cana. Este se quisesse falava português feito Camões. (CALLADO, 1984, p. 155)

Em seguida, observemos o trecho do livro $O$ esqueleto na lagoa verde (CALLADO, 2010, p.103), em que Callado descreve suas percepções de quem era e como vivia o Anta,

O Anta sentou na beira do barranco. Fomos e voltamos ao cabo de uma meia hora e ele ainda estava no mesmo lugar. Tinha uma história pronta a contar, uma perna machucada que não queria meter n'água antes de se escarificar (...). Tanto os índios como, sem dúvida, os caraíbas pareciam gostar dele. Era simpático, risonho, pronto a fazer pequenos serviços e sabendo evitar os grandes com graça e boas desculpas, sem jamais se confundir com o malando congênito, que nada quer fazer apenas para ficar sem fazer nada. $\mathrm{O}$ Anta, em suma, em toda a tribo, parecia o mais próximo de ser aquilo a que damos o nome de artista (...) Quando ele me apareceu um dia no terreiro tocando uma flauta, confirmaram-se as minhas suspeitas.

Em Quarup a figuração do indígena se estabelece como uma retomada ao indianismo romântico, por aspectos que iremos analisar de forma mais precisa no último capítulo, todavia é um momento da literatura em que não é mais possível tratar de forma amena o choque dizimador dos povos indígenas provocados pelo colonizador. Neste sentido, também não é possível ignorar que as questões indígenas, na maioria das vezes, são utilizadas como manobra de promoção política e que em raros casos há um interesse real de preservação da etnia e cultura desses povos.

Martinelli (2006) aborda uma questão caríssima para esta pesquisa, na aproximação entre jornalista de esquerda e literato:

não deixava de ser uma forma de penetração no mercado cultural e uma forma de se posicionar no campo literário, no caso como Sentinela do Bem, como aliás convém a qualquer escritor engajado. E que esta posição artística se coadunava com a de jornalista da grande imprensa burguesa. (MARTINELLI, 2006, p.71-72)

Contudo, não podemos negar que a produção literária de Callado refletia seu envolvimento na superação do subdesenvolvimento e da pobreza do país e seu engajamento se dava, justamente, por essa consciência de atraso e subdesenvolvimento. Ainda que a censura 
tenha sido uma medida permanente durante o período da ditadura, também foram tomadas inúmeras medidas que desenvolveram órgão de contenção, mas também de estímulo como, por exemplo, Concine (Conselho Nacional de Cinema), em 1976, e a Funarte (Fundação Nacional de Arte), em 1975.

Segundo Pellegrini (2014, p.7),

Articulam-se, portanto, nesses documentos, metas muito claras de consolidação da indústria cultural no Brasil, que já existia de forma incipiente, com muito de artesanal e voluntário, desde décadas anteriores (lembre-se, por exemplo, da "era do rádio"), e cuja importância política, institucional e econômica, nesse momento, é estratégica para o projeto modernizador do regime.

Assim, esses temas, que eram compatíveis com a causa e com os escritores de esquerda encontravam um mercado receptivo. Essa recepção incluía o Estado, como também a Igreja e os grandes veículos de comunicação, que continuavam a determinar a produção cultural e a receber investimentos. Dessa forma, para Martinelli (2014), a opinião dos grandes jornais estava diretamente relacionada aos seus interesses empresariais e para exemplificar isso descreve o caso da série de reportagens produzida por Callado com tema sobre a reforma agrária,

Embora contrário à reforma agrária, o Correio da Manhã publicou as reportagens efetuadas por Callado em fins de 1959 no Nordeste, sobre as Ligas Camponesas nascentes, uma vez que também estava interessado na consolidação da Sudene enquanto agência modernizadora do capitalismo no campo.(MARTINELLI, 2014, p. 80)

Outra aproximação entre fato e ficção é o personagem Januário, claramente inspirado em Francisco Julião, que também era líder das Ligas Camponesas, a quem Callado atribui sua aproximação ao seu maior engajamento tanto político, quanto literário,

Só depois (das reportagens) que eu engajei, critiquei com voz mais alta. Foi depois do meu contato com Julião, Arraes etc., que eu fui insistindo mais na crítica, até entrar em choque com o governo. Então ocorreram aquelas minhas prisões (...). (CALLADO apud LEITE, 1982, p.238)

É neste contato com Francisco Julião que as terras do Engenho da Galiléia, em litígio há quatro anos, são desapropriadas pelo governo de Pernambuco e é nessa viagem ao Nordeste que Antonio Callado produz uma série de reportagens em apoio ao governo de Miguel Arraes como esclarece,

Pretendo, nesta série de reportagens que aqui se inicia, mostrar como me convenci de que o Pernambuco saiu de um marasmo de quatrocentos anos 
para uma marcha redentora. É por enquanto uma revolução manhosa, mas será heroica se for necessária. Eu prefiro, tendo conhecido o Pernambuco de 1959, quando o processo mal despontava no Engenho da Galiléia, ao que lá vi agora. E acho que se o atual governador não aprovasse o que está acontecendo no Estado, não haveria uns poucos camponeses mortos, e sim chacinas e o IV Exército garantindo a ordem. Acho que é uma revolução que merece viver. Acho, mesmo, que não precisa de licença de ninguém para viver. (CALLADO, 1979, p.61)

Segundo Brandileone (2010, P. 21), essa aproximação entre literatura e jornalismo no Brasil e a presença constante de escritores nas redações dos grandes jornais brasileiros "levaram a contribuição da literatura para o jornalismo através de sua produção cronista, gênero híbrido que transita entre o fato e a ficção", particularidade de autores como Carlos Drummond de Andrade, Érico Veríssimo, Rubem Braga e outros. Todavia, Antonio Callado era um jornalista que também era escritor, na via contrária acabou trazendo elementos estéticos do jornalismo para sua produção literária, como buscamos exemplificar com a construção estética dos personagens Anta e de Januário.

Essa mescla entre jornalismo e literatura é denominada, nos Estados Unidos na década de 60, com o termo literary journalism ou new journalism para designar um novo gênero que então rompia com os limites convencionais do jornalismo ao se valer de técnicas literárias (BRANDILEONE, 2010, p. 19). No Brasil, no entanto, é somente nas décadas de 1960 e 1970 que o jornalismo literário começa a ter um papel relevante em forma de romance-reportagem. Este se configura, como,

um gênero que resultou do entrecruzamento do gênero 'literário' com o gênero 'não-literário' da reportagem, ou em outras palavras, da intersecção das marcas constitutivas e condicionadoras da narrativa romanesca e da narrativa jornalística" (COSSON, 2001, p. 32 apud BRANDILEONE, 2010).

Em particular, no Brasil, esse novo gênero ganha apreciadores devido à ditadura e a espreita que cercava as produções literárias naquele momento. É, contudo, outro aspecto que já discutimos neste capítulo que traz eficácia a esse gênero. A literatura empenhada - conceito desenvolvido por Candido (2009) - vista na literatura brasileira, mas também na literatura da América Latina de forma geral, como aquela que busca contemplar e intervir na realidade do país através da escrita é o fator que impulsiona o romance reportagem, uma vez que para Flora Sussekid "não é o romanesco, o literário, o que importa, mas a possibilidade de tais narrativas retratarem com "verdade" e "honestidade" aspectos da "realidade brasileira" (SUSSEKID, 1984, p.38 apud BRANDILEONE, 2010 ). 
Em 1968, quando era correspondente, Antonio Callado participou da cobertura da guerra do Vietnã, sendo o único jornalista sul-americano a entrar em Hanói, capital do Vietnã. Em 1967, ano de publicação de Quarup, foi cassado pelo regime militar e perdeu seus direitos políticos por dez anos. No entanto, o conjunto de obras literárias de Callado, e mesmo suas produções jornalísticas, são marcadas pelo anseio de uma transformação social e pelos questionamentos das ações dos movimentos de esquerda no Brasil e no mundo. Quatro anos após ser cassado pelo regime militar e a publicação de Quarup, Callado publica a novela Bar Don Juan (1971) em que demonstra sua total descrença na luta armada contra a ditadura.

Ao lermos a obra de Callado, suas entrevistas e reportagens, é possível perceber um movimento pendular que revela uma questão importantíssima sobre a relutância e a crise da utopia em intelectuais contemporâneos a ele apresentados, principalmente, em Nando. Dessa forma, se Quarup possui o enredo que levanta a utopia da transformação político-social do país, por outro lado suas obras subsequentes Bar Don Juan (1971), Reflexos do Baile (1976) e Sempreviva (1980) revelam em suas temáticas desiludidas o cenário de repressão e censura que acometia o país. Todavia, mesmo sendo um autor que se ligava profundamente ao seu momento histórico e suas obras demonstram um,

Mergulho no local e no histórico que resulta a concretização desses temas universais: pelo confronto das classes sociais em luta no Nordeste, chega-se à temática mais geral da exploração e do homem pelo homem e das centelhas de revolta que periodicamente acendem fogueiras entre os dominados; pela história individual do padre Nando, tematiza-se a situação geral da Igreja, dos padres e do intelectual que se debate entre dois mundos; pela sondagem da consciência de torturadores brasileiros, chega a esboçar uma espécie de tratado da maldade, que nos faz vislumbrar os abismos de todos nós. (LEITE, 1982, p. 100)

Antonio Candido, no texto A nova narrativa (2006b, p.208), esclarece que a produção literária da década de 70 é marcada por uma "legitimação da pluralidade" que,

Resultam textos indefiníveis: romances que mais parecem reportagens (...) A ficção recebe na carne mais sensível o impacto do bom jornalístico moderno, do espantoso incremento de revistas e pequenos seminários da propaganda, da televisão, das vanguardas poéticas que atuam desde o fim dos anos 50, sobretudo o concretismo, storm-center que abalou hábitos mentais, inclusive porque se apoiou em reflexão teórica exigente. (CANDIDO, 2006b, p. 208)

Quarup tem muito do jornalismo de Callado, inclusive por estabelecer essa constante comunicação entre os fatos e a ficção que se fazia necessária devido à censura imposta aos documentos oficiais naquele momento, aspectos, que como vimos anteriormente, se apoiam nas implicações ideológicas e estéticas do romance reportagem. Antonio Callado e 
outros escritores como, por exemplo, Ivan Angelo foram autores que incorporaram procedimentos jornalísticos na literatura, de uma certa forma como herança dos escritores Euclides da Cunha e Lima Barreto.

Neste sentido, a trajetória de Nando revela as transformações da nação em seu percurso histórico e, assim, o amadurecimento do padre se torna também o da consciência nacional. Para Gullar (1967, p.258), Quarup pode ser considerado como um "romance realista porque a ação dos personagens se desenvolve em função de fatos concretos. Não se trata, porém, de um realismo que apenas constate a vida como ela é, mas que (...) indaga a vida como ela deve ser".

Segundo Antonio Candido (2006a, p. 26), a formação da literatura brasileira sempre esteve vinculada ao empenho dos escritores de considerarem "a atividade literária como parte do esforço de construção do país livre". Candido ressalta em Quarup seu aspecto inovador,

Na ficção, o decênio de 60 teve algumas manifestações fortes na linha mais ou menos tradicional de fatura, como os romances - de Antonio Callado, que renovou a "literatura participante" com destemor e perícia, tornando-se o primeiro cronista de qualidade do golpe militar em Quarup (1967), a que seguiria a história desabusada da esquerda aventureira em Bar Don Juan (1971). (CANDIDO, 2006b, p. 208)

Ao analisarmos a obra de Callado notamos claramente essa herança de compreender e dar conta do país através da literatura. Podemos ainda afirmar que o escritor desenvolveu um projeto crítico e estético voltado para o entendimento histórico do Brasil. Callado era um intelectual consciente de seu papel no contexto social brasileiro e, para, além disso, assumia sua responsabilidade de intelectual latino-americano,

Quem escreve, pensa. Porque o Brasil precisa da gente. A verdade é essa. Há países que podem prescindir do intelectual. A França, será que precisava muito do Mallarmé? Acho que não. Tem tanto estadista importante. Um país tão rico de tudo quanto há intelectualmente falando. O Mallarmé podia ficar no canto dele, fazendo a poesia dele, sem sequer se preocupar ou achar que estava recusando uma participação no futuro da França. A França não precisava de Mallarmé, como tal, como França, como país. (...) O intelectual latino-americano - ele sim - devia se compenetrar de que a divisão do trabalho é ainda muito mal feita na América Latina. $\mathrm{O}$ intelectual não pode dizer: 'Eu sou um intelectual; prefiro a minha torre de marfim, não quero saber de mais nada.' Eu acho que um intelectual pode ser um Mallarmé, mas o Mallarmé tem que ter uma opinião sobre o que está acontecendo no país dele, sobretudo se houver uma crise. O Mallarmé mesmo não podia ignorar uma guerra na França. Ele tinha de ter opinião. O Proust lutou pelo Dreyfus. Não é porque era judeu. O Proust era judeu muito avacalhado. De terceiro 
time, inclusive, era meio-sangue. Mas lutou pelo Dreyfus, em nome da liberdade. Ele achou que aquele homem estava sendo violentado, esculhambado; ele não tinha culpa. O Proust participou daquilo, não tanto como o Zola (que participou muitíssimo), mas participou. O próprio RobertGrillet, homem do nouveau roman, do romance praticamente hermético, sabe que ele lutava ao lado do Sartre contra o recrutamento para a guerra da Argélia? Era um intelectual, sua obra de um lado, de outro, sua participação na política de um país que precisava muito menos deles, do que o Brasil precisa de nós, ou a Argentina precisa de um Borges. (CALLADO apud LEITE, 1982, p. 236)

Em 1980, com a abertura política, a obra de Callado parece tomar novos rumos, mais uma vez acompanhando o fluxo político, e o autor publica Expedição Montaigne (1982), Concerto Carioca (1985), Memórias de Aldenham House (1989). Sobre essas obras Ligia Chiapini Leite (1982, p.221) esclarece que,

é como se, em cada livro posterior, Callado desdobrasse Quarup, aprofundando e atualizando, muitas vezes pela negação, uma de suas múltiplas vertentes. Assim, Bar Don Juan, Reflexos do Baile e Sempreviva retomam as andanças do padre Nando, procurando retratar diferentes brasis (das guerrilhas, dos sequestros, do submundo dos torturadores e torturados). O que se busca são sempre alternativas para o "atoleiro em que o Brasil se meteu", embora cada vez mais desesperança, com ironia minando a epopéia e desvendando o quixotesco nas mais belas utopias. (LEITE, 1982, p.221)

Por isso, é possível afirmar que Quarup é um núcleo irradiador de questões na obra de Callado, já que é a partir dele, e sua justificativa da revolução como agente transformador dos problemas nacionais, que sua produção romanesca segue nas obras subsequentes revelando a desesperança dos anos que se seguem após o golpe militar. Aliadas a isso estão as características centrais recorrentes na obra de Callado: política, história e religiosidade. Além da utopia, do desencanto e da ironia que, provavelmente, são heranças da carreira jornalística do autor.

Ainda que Callado seja um escritor ligado à tradição desenvolvida com empenho pelos românticos para explicar e compreender o país através da literatura, Lígia Chiappini Leite revela aspectos de superação imprescindíveis para esta pesquisa,

(...) o escritor que deu os seus primeiros passos na esteira do romance católico, preocupado com as grandes batalhas desenroladas na consciência do homem, não abandonará de todo o terreno íntimo. A tensão entre a perspectiva externa do romance histórico-político e a perspectiva interna do romance intimista, com maior ou menor insistência, será uma característica da ficção de Callado, de Quarup a Sempreviva e Expedição Montaigne (...). Essa dimensão interna vai minando ironicamente, já desde Quarup, o tom eufórico do romance que, na trilha de Alencar e Gonçalves Dias, redescobre um Brasil gigante, de belas florestas, belas flores e belas Iracemas. É uma tendência contrária àquela, menos evidente; é talvez Machado com sua 
ironia e seu profundo ceticismo que vai tomando conta dessa ficção de início tão esperançosa nos destinos do País Novo e exuberante. É a desconfiança minando as certezas na vitória da revolução. (LEITE, 1982, p. 146)

Quarup é, portanto, a tentativa de problematização das questões pós-golpe militar, a reorganização histórica e geográfica para um escritor que passou anos fora do país, mas também atualizações de questões ligadas a nossa formação nacional que estão presentes na nossa literatura desde José de Alencar, como Chiappini esclarece,

No entanto, se em Quarup não aparecia ainda, explicitamente, uma reflexão sobre o processo de construção do romance, ele já demonstrava o mal estar da ficção realista no século XX e se a intenção primeira do escritor era traçar um novo Retrato do Brasil, 'organizando o país' na sua cabeça, e no papel, esse retrato aparece como novo justamente porque a ficção o transforma num retrato plural contraditório, onde se expõe o descaráter brasileiro, pelo contraponto de perspectivas em jogo que ironicamente subvertem o projeto alencariano de representação de nacionalidade harmônica, estilhaçadas nos retratos desfocados pela fantasia de cada um. (LEITE, 1983a, p. 149)

Contudo, Quarup mesmo com uma historicidade tão marcada pelos problemas sociais nacionais consegue alcançar uma certa universalidade em sua elaboração estética,

De fato, Quarup falou aos leitores da década de 60, nacionalistas, desenvolvimentistas, populistas, anti imperialistas, pequeno-burgueses e 'revolucionários'. Mas continua falando aos leitores de 90, ainda pequenos burgueses, porém mais cosmopolitas e céticos tanto diante dos programas desenvolvimentistas e modernizadores quanto diante dos radicalismos de uma esquerda festiva. E consegue essa façanha porque é um livro profundamente histórico e profundamente artístico, desmentindo os preconceitos que freqüentemente levam a crítica a opor o histórico ao estético. (LEITE, 1994, p. 30)

Como vemos tentando explicitar, Callado é um escritor que busca elaborar um projeto político em suas obras literárias considerando seus interesses. Neste sentido, Lukács (1970) desenvolve o conceito de arte autêntica - que devemos compreender como a arte capaz de revelar a realidade e suas conexões - precisa ser capaz de elevar a subjetividade do autor à condição genérica, o que significa levar as preocupações do autor ao nível de preocupações do gênero humano. A respeito disso, do que chamou de subjetividade estética, Lukács esclarece,

A subjetividade dos que participam criativamente da obra unitária tem assim valor positivo, significativo do ponto de vista estético, tão somente enquanto for capaz de se tornar um elemento estrutural orgânico da individualidade do autor. As subjetividades imediatas, particulares, são, porém incomensuráveis em sua singularidade de mônadas. (LUKÁCS, 1970, p. 181)

Sabemos que os problemas sociais do Brasil, as questões dos índios e as desigualdades sociais são preocupações de Callado que o escritor transfere para sua obra 
literária, todavia, ainda que um leitor não esteja inteirado do contexto brasileiro é capaz de se conectar à obra literária através do seu caráter genérico de seu desenvolvimento que se elevou de subjetivo a genérico. Contudo, quando o artista é capaz de superar a subjetividade imediata não significa que deva perder seu aspecto subjetivo e pessoal. Para Lukács (1970, p. 181),

a objetividade é aferida pelo modo como uma subjetividade assim universalizada na particularidade - subjetividade que com isso, ao mesmo tempo, como vimos, introduz também a unive rsalidade como momento no seu meio organizador - é capaz de dar uma reprodução da realidade, verdadeira e original, que possua eficácia imediata.

Quarup é construído para se tornar um retrato policrônico da identidade brasileira, elaborado metaforicamente como uma aldeia e suas malocas revelando nos personagens e seus planos sociais diferentes pontos de vista sobre o Brasil. Essa estrutura supera as limitações de representação da imagem do país fragmentada em sua constituição histórica, cultural e social e aprisionada a um clichê imutável. Dessa forma, essa análise de Quarup que o encara como uma aldeia vista por cima com inúmeras habitações em que cada uma guarda um significado próprio e todas interferem de forma significativa no resultado final nos leva à percepção de que Nando não é figurado no romance como um personagem principal - a não ser pela frequência de suas ações - ele nos parece mais um catalisador entre os acontecimentos e os personagens, pela qual se reúnem as demais visões do itinerário narrativo e ideológico.

Como vimos, Callado tinha um projeto com suas obras literárias que, ligado ao desejo de organizar e ainda descobrir a história, social e política do país, buscava visar novos caminhos para mudanças diante da negatividade e da desesperança dos anos de ditadura. Quarup é, portanto, a visão condensada de diferentes brasis, suas possibilidades e impossibilidades que são figuradas a partir dos interesses e problematizações que estavam na vida pessoal e profissional de Callado e que são mantidas no texto. Há, no entanto, na obra de Callado uma superação da literatura empenhada dos escritores românticos do século XIX, já que ela não faz mais parte de um projeto de nação, uma vez que, naquele momento, a nação não se completa. E é por essa sensação de incompletude que Callado se manifesta como intelectual engajado através da sua ocupação pública, no caso, o jornalismo. 


\section{CAPÍTULO 4}

\section{QUARUP: TRADIÇÃO E SUPERAÇÃO}

Neste último capítulo faremos uma análise mais detalhada do romance Quarup, publicado por Antonio Callado em 1967, recuperando na argumentação questões e pressupostos que foram elencados nos capítulos anteriores. Em nossa análise evidenciaremos na narrativa questões que revelem a relação entre fato estético e fato histórico apontando as aproximações e os distanciamentos do indianismo visto através da obra de Antonio Callado.

Darcy Ribeiro, em seu texto Gentilidades, alerta "que é a história senão esta reconstituição alegórica do passado vivente que nos ajuda a compor nosso próprio discurso sobre o que estamos sendo?" (RIBEIRO, 2011, p. 25). Nesta perspectiva consideraremos a literatura como história quando essa é capaz de partindo da transfiguração do imediato revelar o verdadeiro reflexo da vida. Neste sentido este capítulo tratará de analisar a literarização do elemento estético indígena ligada à estrutura histórica do Brasil.

Antonio Candido (2006a), em seu texto Crítica e Sociologia, desenvolve o princípio estruturante, que nos é de grande valia para este capítulo. Sabemos que a análise crítica que considera não apenas o texto em si, como também elementos "externos" a ele pode, facilmente, se deixar levar por uma apreciação que separe elementos "externos" de "internos", o que - para este trabalho - seria um aspecto que implicaria em uma análise simplista da obra. No entanto, Candido esclarece que devemos realizar uma crítica que leve em consideração,

o elemento social, não exteriormente, como referência que permite identificar, na matéria do livro, a expressão de uma certa época ou de uma sociedade determinada: nem como enquadramento, que permite situá-lo historicamente: mas como fator da própria construção artística, estudado no nível explicativo e não ilustrativo. (CANDIDO, 2006a, p. 15-15, grifo meu)

Isto é, quando é possível elaborar uma crítica que integre aspectos, anteriormente, periféricos da obra como - a história e a sociologia - o que era de fora da obra se torna intrínseco a ela. Afinal, segundo Candido é,

neste nível de análise, em que a estrutura constitui o ponto de referência, as divisões pouco importam, pois tudo se transforma, para o crítico, em 
fermento orgânico de que resultou a diversidade coesa do todo. (2006a, p. 16)

Diante disso, consideramos que para este capítulo - assim como para todo este trabalho - a literarização do elemento indígena teve sempre uma função social e política na literatura o que nos leva de forma direta à ligação com a estrutura histórica do país como “componente da estruturação da obra" (CANDIDO, 2006a, p. 16).

Ao encararmos esses elementos como parte intrínseca à obra nos afastamos da perspectiva crítica que enxerga Quarup somente como uma eficaz elaboração sócio histórica ressaltando neste capítulo a valorização da construção estética de Callado que supera tais limitações. Dessa forma, para Arrigucci Jr (1999, p. 316),

Callado não adotou a perplexidade moderna sobre os impasses da narração, mas sempre de olho na história contemporânea em especial na de seu país, se arriscou nos meandros e dificuldades de como contá-la junto ao que imagina. O seu realismo crítico avança desconfiado de si mesmo e acaba deixando-se infiltrar por brechas que o desconcertam no meio do mato, aonde é levado a repensar os descaminhos de nossa já velha civilização litorânea. Aí nesse centro isolado, pode se deparar com imagens medonhas, como a do terrível formigueiro - 'o maior panelão de saúva' - por onde somem em Quarup, as esperanças últimas do encontro do centro geográfico e do verdadeiro coração do Brasil. Na intersecção de natureza e história, sua prosa de ficção buscará imagens que, com força alegórica, espelhem a inabarcável totalidade.

Para tanto, analisaremos elementos do tema e da composição de Quarup, buscando compreender que a obra de Callado é herdeira do indianismo romântico. Todavia, naquele momento já não está mais a serviço da construção da nação romântica - ainda que ela não esteja em sua forma inteiriça - e, por isso, é capaz de uma literarização do elemento indígena mais ampla e consciente. Todavia, essa retomada da temática indígena só revela como esse ainda é um problema para a história do país.

Quarup é uma obra narrada em terceira pessoa por um narrador onisciente, uma vez que ele parece "atravessar" os personagens revelando seus pensamentos e sentimentos. Durante a narrativa a voz do narrador e a do personagem central, Nando, se fundem e se confundem, até que em um certo ponto da narrativa essa busca por uma neutralidade do discurso do narrador se perde e os elementos que constituem o "mundo" ficcional de Callado, personagens e enredo são revelados a partir do protagonista.

Podemos inferir que, para o autor, o narrador parece não ter reconhecido seu protagonista. A incerteza do narrador diante da escolha do narrador também nos parece com a incerteza de Callado sobre quem ou qual camada social seria capaz de protagonizar nossa 
história naquele momento. Situação compreensível se considerarmos as incertezas e impossibilidades do momento da ditadura militar brasileira.

Neste momento nos interessa compreender que essa incerteza do protagonista e do narrador se liga diretamente ao conceito de focalização que pode ser definida como "a representação da informação diegética que se encontra ao alcance de um determinado campo de consciência" (REIS; LOPES, 1988, p.119). Dessa forma, a focalização controla a quantidade de informações que aparecem na narrativa, tendo em vista que, a seleção dessas informações depende da focalização.

Desse modo, podemos analisar o narrador e, por sua vez, a focalização de Quarup que se figura na narrativa ainda por um narrador heterodiegético, ou seja - um narrador que narra uma história da qual não participa - centralizando na focalização onisciente, dado que, "faz uso de uma capacidade de conhecimento praticamente ilimitada" (REIS; LOPES, 1988, p. 255), quando "atravessa" os personagens, como dito anteriormente.

Quarup quase que completamente é construído por diálogos - o que parece ter sido a solução encontrada por Callado para dar conta de tantas vozes na narrativa - no entanto, é devido à focalização onisciente que se torna possível para o narrador construir um discursivo multisseletivo, que é capaz de se aproximar do interior dos personagens.

Quarup segue o tempo narrativo cronológico que compreende um período de dez anos que se inicia no segundo governo de Getúlio Vargas, entre os anos de 1950 e 1964. A narrativa ainda perpassa a deposição de João Goulart pelo golpe militar de 1964 e o estabelecimento da ditadura no Brasil. Quarup passa por diversos espaços geográficos como, por exemplo, o Xingu e o Rio de Janeiro, mas inicia e termina em Pernambuco. A história de transformação e evolução de Nando, que em certa medida é também a do Brasil, é estruturada em sete extensos capítulos, são eles: "O Ossuário”, “O Éter”, “A Maçã”, “A Orquídea”, “A Palavra", "A Praia" e "O Mundo de Francisca".

Como dito, anteriormente, nem sempre em Quarup o personagem principal é Nando, a não ser pela frequência das suas ações, mas não por sua centralidade, uma vez que entendemos que outras vozes e outros personagens disputam essa posição central. Parte dessa percepção de enxergar Nando como protagonista, talvez, seja explicada pela noção de tempo 
da história e tempo do discurso ${ }^{19}$ adotada por Reis e Lopes (1988, p.296), em Dicionário da Teoria Narrativa, estes esclarecem que,

A imagem da história que, através do discurso, o leitor vai configurando não é indiferente a efeitos temporais, constituídos a partir de certos procedimentos discursivos: assim, se um relato distanciado, de tipo onisciente, faculta da história a imagem temporal de um conjunto de um conjunto de eventos claramente passados, já uma representação em que o centro da orientação do leitor se situa na consciência de uma personagem ou num observador imaginário na cena da ação ficcional pode leva-lo a sentir essa ação como presente.

Dessa forma, a partir da construção da narrativa através da perspectiva e experiências de Nando, Quarup centra-se na figura do padre e sua trajetória pessoal. A personagem no início da narrativa mora no Mosteiro em Recife e nutre a ideia de construir, juntamente com os índios, no Alto Xingu, uma sociedade utópica que teria sido pensada pelos jesuítas, uma república teocrática e comunista que valorizaria o homem primitivo. Assim, Nando ignora os valores e costumes dos indígenas e considera, apenas, que a "missão" dos jesuítas era motivada pela necessidade dos índios de conversão ao cristianismo,

Se amolo vocês com minhas histórias - disse Nando - prometo não voltar ao assunto. Mas palavra que eu gostaria de ver a República Comunista dos Guaranis estudada pelos biologistas. Os jesuítas das Missões não aceleram a história de um povo. Aceleram a evolução de um povo. (CALLADO, 1984, p. 28)

Em nossa análise cabe compreendermos como o índio representado em Quarup é uma herança do índio romântico, mas também é uma nova representação do Brasil do século XX. Neste sentido, é importante para este trabalho, dentro da nossa perspectiva, estabelecer algumas relações entre fator estético e fator histórico. Assim, para compreendermos o índio literarizado na obra de Callado que se apresenta de forma multiétnica e pluralizado acreditamos ser necessário uma breve explicitação histórica do contexto da criação do Parque Indígena do Xingu.

Historicamente, a criação do Parque Indígena do Xingu (PIX) inicia-se com a expedição Roncador-Xingu - que tinha como participantes os irmãos Villas-Boas- foi a primeira no contexto da marcha para o Oeste com o objetivo de ocupar o centro-oeste brasileiro. O parque foi criado em 1961, mas desde 1952 já ocorriam discussões a respeito de

\footnotetext{
${ }^{19}$ Reis e Lopes (1988,p.294) estabelecem a distinção entre tempo da história e tempo do discurso. Para eles o "tempo da história é múltiplo e a sua vivência desdobra-se pela diversidade de personagens que povoam o universo diegético; por sua vez o tempo do discurso é linear e sujeita o tempo da história à dinâmica de sucessividade metonímica própria da narrativa.
} 
sua criação. Quando o então presidente Jânio Quadros cria o Parque ele beneficia o território de forma integral de algumas etnias, por outro lado, outros povos que viviam naquele território perderam suas terras. De fato, a criação do Parque contribuiu para a preservação de povos indígenas, como os Caiabi que sofriam uma dizimação por epidemias trazidas no contato com os homens brancos da expedição, no entanto, também trouxe prejuízo de

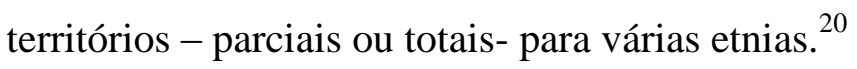

Segundo Silva, Santana e Betrão (2014, p. 197),

Por volta de 1961, aviões do Exército Brasileiro campeavam povos indígenas nas mais diversas regiões do Brasil com o objetivo oficial de preservar suas identidades em uma região única. Assim, ex abrupto, grupos inteiros foram transportados para a primeira demarcação indígena brasileira e obrigados a encontrar uma unidade multiétnica que lhes asseguraria a preservação diante do contato da exploradora e voraz sociedade do homem branco.

Diante dessas informações somos levados a avaliar que a narrativa tendo como título Quarup e, portanto, presumidamente com a temática indígena definida como principal, parece se perder, ou talvez, diluir entre tantos temas políticos e sociais - êxodo rural, Igreja, transferência da Capital da República entre outros - deixando de completar de forma mais inteiriça a complexa criação de um parque que agrupou tantas etnias indígenas.

Ao analisarmos o primeiro momento de Nando na narrativa podemos identificar nele aspectos da descrição feita por Georg Lukács, em Teoria do Romance, designada pelo crítico como "idealismo abstrato", identificando o personagem de Nando como "herói problemático. Para Lukács (2000, p. 110), “o espírito fundamental do romance, aquele que lhe determina a forma, objetiva-se como psicologia dos heróis romanescos: esses heróis estão sempre em busca", que se configura na supervalorização da busca pelo sentido da vida que já não se encontra no próprio indivíduo.

Nesta perspectiva, aproximaremos a construção de Nando ao conceito do herói do romance de formação. De forma consciente resguardamos as diferenças entre Nando e o típico herói do romance de formação, segundo Bakhtin (20015, p. 221), que "desenha uma trajetória tipicamente recidiva de formação do homem, que vai do idealismo juvenil e da natureza sonhadora à sobriedade madura", ou ainda, do tipo "biográfico". Consideramos,

\footnotetext{
${ }^{20}$ Informações disponíveis em < http://www.axa.org.br/anexo/no-ponto-sociedade/> Acessado em: 5 de novembro de 2015.
} 
portanto, Quarup e por sua vez a construção de Nando com relevantes aproximações do quinto tipo de romance formação ${ }^{21}$ elencado por Bakhtin como,

[...] o mais importante. Nele a formação do homem se apresenta em indissolúvel relação com a formação histórica. A formação do homem efetua-se no tempo histórico real a sua necessidade, com sua plenitude, com seu futuro, com seu caráter profundamente cronotópico [...] Os elementos de tal formação histórica do homem existem em toda parte onde quer que se tenha atingido um domínio considerável do tempo histórico real. (BAKHTIN, 2015, p. 221-222)

Não podemos considerar, categoricamente, Quarup como romance de formação dos tipos ditos anteriormente, segundo Bakhtin, devido tanto a sua estrutura narrativa - tempo - como quanto ao protagonista, tendo em vista que, Nando já é um homem formado no início do romance. Todavia, é a busca em que Nando se envolve que dá ao romance o caráter de formação, no sentido de que não é mais uma busca exterior que guia a narrativa e o personagem, mas sim uma busca interior do personagem e, dessa forma, a "problemática não reside em suas "falsas tendências", mas precisamente no fato de querer realizar, de algum modo, o âmago de sua interioridade no mundo" (LUKÁCS, 2012, p.142).

Além disso, segundo essa teoria - o quinto tipo de romance de formação bakhtiniana - que o "homem se forma ao mesmo tempo que o mundo reflete" (BAKHTIN, 2015, p. 221) nos leva a ligar diretamente que a saga de Nando em busca do centro do Brasil para criação de uma sociedade utópica se revelará na narrativa como um desejo coletivo de transformação social. Neste sentido, para Lukács (2012, p.140), “o herói é selecionado entre o número ilimitado dos aspirantes e posto no centro da narrativa somente porque sua busca e sua descoberta revelam, com máxima nitidez, a totalidade do mundo".

Nando se apresenta no primeiro momento da narrativa fechado demais em um projeto ideológico a ponto de ser incapaz de avaliar as condições absurdas e que ignoram a realidade histórica dos fatos. É, somente, devido à elaboração do narrador onisciente que podemos, por exemplo, observar sentimentos íntimos de Nando em diálogo com Levindo e sua total ignorância e alienação a respeito da violência que ocorria fora do mosteiro, como no trecho,

\footnotetext{
${ }^{21}$ Bakhtin (2015, p. 220-221) classifica o romance de formação em cinco tipos, são eles: o primeiro, no "tempo idílico pode-se mostrar a trajetória do homem entre a infância e a mocidade e entre a maturidade e a velhice"; o segundo, de formação cíclica "que vai do idealismo juvenil e da natureza sonhadora à sobriedade madura e ao praticismo"; formação do tipo biográfico "se processa no tempo biográfico"; quarta, "é o romance didáticopedagógico" e a quinta é a que explicitamos no texto.
} 
Levindo continuou desfiando a história da chegada da Polícia, das arrogâncias de Zé Quincas e das condições de trabalho escravo que impunha aos lavradores, mas Nando fitava com desalento a mancha de sangue no marfim ilustre da caveira franciscana. Uma profanação, o episódio de loucura e violência vindo desaguar no ossuário. $O$ sangue de um jovem desmiolado a manchar quem só aguardava o sangue da Ressureição. Que tinha Levindo a fazer ali, santo Deus? (CALLADO, 1984, p. 11-12)

É, pois, somente quando Nando decide sair do mosteiro e começa a ter contato com pessoas de fora do seu círculo de convivência que ele se torna capaz de questionar seus projetos ideológicos,

Desde que D. Anselmo lhe dera permissão - mais do que isto, lhe ordenara que saísse do Mosteiro, que fizesse relações com gente do mundo, Nando só tinha encontrado uma paz séria e tranquila em Francisca, noiva de Levindo. $\mathrm{O}$ mais era o desmembramento, o mundo entrando em filetes de distração por todas as frinchas da fortaleza que ele fora antigamente. A convivência com seus amigos era estimulante mas agora o levava quase ao desespero, de tanto que o tirava de dentro de si. (CALLADO, 1984, p. 12)

Esse momento de choque com seus projetos é, portanto, o início da passagem do estritamente individual para o desejo impulsionador coletivo de transformação. Esse marco da narrativa também revela, se considerarmos o posicionamento crítico de Callado diante do papel dos escritores, como uma metáfora do intelectual que alienado em suas convicções e certezas dogmáticas não consegue perceber a realidade política e social ao seu redor. Como esclarece Martinelli (2006, p. 218), "Quarup como um romance de deseducação do intelectual. Daquele intelectual que vai perdendo sua concepção de mundo mais direta com a realidade que o cerca", ou ainda, para Gullar (1967, p. 258) a "deseducação" a que Nando é submetido na narrativa se revela como exemplo libertário de um ponto de partida para transformações necessárias não somente para ele, mas para o país.

Antes de ir para o Xingu, Nando passa um período no Rio de Janeiro, e é lá que ele tem contato com o Serviço de Proteção ao Índio (SPI), que hoje conhecemos como Funai (Fundação Nacional do Índio) $^{22}$. É nesse momento da narrativa que Nando tem uma variedade de experiências sexuais e com drogas, especificamente, o lança perfume. Ao partir,

\footnotetext{
${ }^{22}$ Segundo informações disponíveis em < http://www.funai.gov.br/index.php/nossas-acoes/politica-indigenista >, acessado em 2 de novembro de 2015, A Funai tem suas origens no extinto SPILTN (Serviço de Proteção aos Índios e Localização de Trabalhadores Nacionais). O SPILTN foi criado pelo Decreto de Lei $\mathrm{n}^{\circ}$ 8.072, de 20 de junho de 1910. Tal órgão teve como objetivo ser o órgão do Governo Federal responsável de executar as políticas indigenistas. A criação do SPI fez com que a lgreja deixasse de ter hegemonia no trabalho de assistência junto aos índios. A Funai, por sua vez, foi criada por meio da Lei n. ${ }^{\circ} 5.371$, em 5 de dezembro de 1967, no entanto, somente com a Lei n. ${ }^{\circ} 6.001$ de 19 de dezembro de 1973 (conhecida como Estatuto do Índio) que foram formalizados os procedimentos a serem adotados pela Funai para proteger e assistir as populações indígenas, inclusive no que diz respeito à definição de suas terras e ao processo de regularização fundiária.
} 
finalmente, para o Xingu, outros personagens começam a ganhar destaque, como: Ramiro, um dos líderes do SPI; sua sobrinha e secretária Vanda, que de forma curiosa diz que "tio Ramiro arranjou todas as respostas às perguntas da prova que eu prestei, depois me requisitou para secretária dele" (CALLADO, 1984, .100); Sônia que é representada na narrativa como uma mulher muito atraente e que durante a narrativa foge com o índio Anta e ainda o sertanista Fontoura.

No capítulo seguinte, todos retornam ao Xingu - menos Sônia que já tinha fugido com o índio Anta - para demarcar o centro do país. Contudo, essa busca pelo "centro" do país é também a busca de Nando por si mesmo, em que durante toda a narrativa se revela como a descoberta do outro e que se reafirma na teoria de Lukács (2009, p. 90) sobre o romance moderno,

O processo assim explicitado como forma interior do romance é a marcha para si do indivíduo problemático, o movimento progressivo que - a partir de uma obscura sujeição à realidade heterogênea puramente existente e privada de significação para o indivíduo leva a um claro conhecimento de si.

É, portanto, nessa busca e experiência tanto individual quanto coletiva que ocorrerá o confronto entre a visão utópica do Brasil idealizada pelo padre e a visão do homem Nando após o abandono do sacerdócio, que se configura no projeto engajado de Antonio Callado que reintegra,

mas que também revela o passado e o presente, tipo humano e estrutura da ação, portanto, são condicionados aqui pela necessidade formal de que a reconciliação entre interioridade e mundo seja problemática, mas possível; de que ela tenha de ser buscada em penosas lutas e descaminhos, mas possa no entanto ser encontrada. (LUKÁCS, 2009, p.138)

Os personagens que surgem no segundo capítulo "O Éter" revelam projetos confusos e individuais tomados pelo tédio e privilégios da classe burguesa, esses personagens se voltam para seus próprios dilemas, que por sua vez, se revelam como os problemas das grandes capitais: as drogas, a corrupção e a política. Aliado a esses problemas também nos parece claro que o escritor busca retratar o aparelho burocrático ocupado pela burguesia na defesa de seus interesses, que só incidentalmente cogitam considerar a realidade do país.

É, pois, neste sentido que temos personagens que representam uma elite com princípios e valores que são incoerentes com os cargos que possuem como, por exemplo, Ramiro - forte defensor da influência francesa - era um dos presidentes do SPI, mas poucas afinidades possuía com a causa indígena, 
Está vendo como é difícil fazer alguma coisa nesse país? Eu aceitei esse abacaxi dos índios por amizade ao Ministro Gouvéia, que devia ser nosso próximo Presidente da República mas que o Dr Getúlio botou num Ministério que é prêmio de consolação. E quando a gente encontra, para um trabalho no meio do mato, que ninguém quer, um cara como Fontoura, dedicado e esforçado apesar de bêbado, é isso que o senhor vê. (CALLADO, 1984, p. 104)

Ao tratar da temática indígena, em pleno século XX, já não é mais possível uma literarização mitificada do índio, pois já não se pode ignorar ou mesmo tratar de forma amena a devastação cometida pela colonização aos povos indígenas, além de como os índios ainda são tratados como manobra política.

Por outro lado, nos é apresentado o personagem Fontoura que é o chefe do Posto Capitão Vasconcelos, no Xingu. Esse personagem levanta questões que englobam a boa vontade, a falta de incentivo governamental e o alcoolismo. Fontoura é o representante do desespero diante da situação dos indígenas Brasil adentro,

- Quando morre uma manada de índios de um sarampo qualquer o Fontoura toma porres intermináveis e tem uma loucura recorrente. Propõe a mim, propõe a todo mundo sempre a mesma coisa, sabe o quê? A invasão do Rio pelos índios.

- De raiva, de ódio. Aterrissar no Rio com vinte aviões de transporte carregados de índios nus e passeá-los pela Avenida Rio Branco, pelas praias. Armá-los de arcos, de sarabatanas, bordunas, trucidar o maior número possível de funcionários públicos, que Fontoura odeia, apesar de ser funcionário ele próprio. Criar um caso, uma guerrilha. Obrigar o Brasil a matar índio na Capital e com bala, em lugar de dizimá-lo às escondidas, pela fome. (CALLADO, 1984, p. 165, grifos meus)

Há uma distinção clara entre o ponto de vista de Fontoura sobre os índios e a ideia que Nando faz dos mesmos. Enquanto Fontoura percebe a situação desfavorável dos índios e a necessidade de resistência para que não só mantenham sua cultura, mas que sobrevivam, Nando ainda possui uma visão pura, idealizada e, portanto, deformada que muito se assemelha aos índios das produções alencarianas. Na narrativa temos um trecho claro, ainda que extenso, dessa distinção de pontos de vista a respeito do indígena,

- Os índios estão quase mortos - disse Fontoura. - O importante é dar a eles os meios para sobreviver.

- Exatamente - disse Nando. - Eu tenho a impressão de que o que desagrada você é a ideia de integrar o índio nas populações do interior, não é? Eles se despersonalizariam, desapareceriam como índios.

Fontoura assentiu com a cabeça. 
- Portanto - continuou Nando se entusiasmando - o que se pode fazer é educá-los de modo a que contribuam para seu sustento com a pesca, a caça, a lavoura, as artes plumárias continuando a se desenvolver como índios. Poderíamos montar aqui peixarias, serrarias...

Fontoura fez que não com a cabeça.

- Não? - disse Nando.

- Não, nunca.

Fontoura se levantou da rede, foi até ao escritório e de lá voltou com um sovado mapa do Mato Grosso onde se delimitara, a lápis de cor vermelho, o Parque Nacional do Xingu, entre 10 e 12 graus de latitude sul e 53 e 54 graus de longitude oeste de Greenwich. A forma inclinada acompanhava o curso do Xingu, das cabeceiras dos seus três formadores até a cachoeira de pedras.

- Este - disse o Fontoura batendo com o dedo em cima da área do Parque - é o Estado dos Índios.

Montoya, Cataldino, Rodrigues, pensou Nando, o coração a lhe bater apressado. Ave, República dos Guaranis.

- Magnífico - disse ele - o estado Indígena.

- Sim, magnífico - disse Fontoura - se fosse realizável. E se fosse possível, de acordo com meus sonhos, estender aqui - e seu dedo passou como se abrisse uma vala pelo contorno do Parque - uma cerca de arame farpado.

- Arame farpado? - disse Nando.

- Sim - disse Fontoura. - Eletrificado. Contra o Brasil.

- E educar os índios de que maneira? Que fazer deles? Que espécie de gente?

- O Estado seria de índios, de bugres, do que eles são - disse Fontoura martelando as sílabas. - Eu não quero transformar índios em nada. Parques imensos, cuidadosamente vigiados, fizeram os ingleses para girafas e zebras em Quênia e Tanganica. Não para educar girafas ou zebras. Para preservá-las vivas.

- Mas os índios têm como nós uma alma imortal - disse Nando.

- Os índios não sei se têm. Ou se ainda têm. Nós eu sei que não temos. No mundo inteiro as reservas indígenas são simples arapucas para extermínio de índios. (Callado, 1984, p.160-1)

Assim, se, para Nando, a catequese católica é a solução para a formação da sociedade brasileira "quero ir em busca dos índios ferozes e trazê-los ao contato da civilização por meio de Cristo" (CALLADO, 1984, p.25), para Fontoura representa a resistência que possibilitará que os credos indígenas permaneçam vivos. Para Santos (2009b), essa visão de 
Fontoura é "um discurso próximo ao que se construiu no Brasil pelos positivistas na formulação da política indigenista, feição da experiência pessoal de Rondon", ainda que,

O que difere ideais da personagem em relação aos positivistas é que acredita na eficácia da proteção do Estado para com a preservação da cultura. Essa face revela, em certa medida, uma mentalidade utópica, porque o histórico do Serviço de Proteção ao Índio no Brasil mostra que, em determinados momentos, foram registrados mais problemas com o enfrentamento dos índios do que sua proteção propriamente eficaz. Mesmo os resultados de Rondon, considerados exemplares na "pacificação" dos indígenas, são passíveis de outra leitura no que compete aos métodos persuasórios de que se utilizou para alcançar as tribos mais aguerridas como os Nambikwara. (SANTOS, 2009b, p. 355-356)

Ao marcar na narrativa discursos tão diferentes Callado constrói Quarup como um romance que se torna "produto da hibridação, um compósito das culturas branca, indígena e dos discursos heterogêneos que constroem uma imagem do Brasil como país incompleto, que está constantemente sendo inventado". (JABLONSKI, 2005, p;106). Quarup, a respeito das questões indígenas, se reveste de maior naturalidade e aproximação com a realidade histórica, afastando-se, portanto, das idealizações comuns na literatura brasileira. Se no Romantismo a representação do índio na literatura só foi possível devido ao genocídio e desaparecimento do povo indígena, em Quarup o índio é representado como uma minoria desfavorecida da sociedade contemporânea sem qualquer aspecto do indianismo romântico. A sua resistência como elemento nacional a se representar é a própria testemunha do genocídio. Assim, para Leite (1982, p. 156),

O contato com os índios de carne e osso vai corrigir diversas ilusões de Nando: a descoberta de que o Paraíso está muito próximo do inferno, a descoberta de que não há muito sentido no projeto civilizador, a revelação de que o índio não é um animal sem conflitos e consciência mas que tem suas convenções, suas injustiças, e que, sobretudo, tem consciência do sofrimento, da doença e do prazer.

Na expedição ao Xingu uma nova e crucial personagem nas ações da narrativa surge, ela é Francisca que morava na Europa e cujo noivo havia sido morto pela polícia em um confronto entre usineiros e camponeses. Levindo - noivo de Francisca no primeiro capítulo "O Ossuário" - surge como um antagonista de Nando, podemos considerar isso tanto pelo interesse amoroso que ambos têm por Francisca, mas, principalmente, pelos ideais e convicções que representam. Diferentemente, de Nando que se apresenta em dúvida quanto a suas aspirações religiosas e sem muita convicção de seus projetos utópicos, Levindo é o representante do programa socialista-comunista e se posiciona enfaticamente contra o sistema capitalista. 
Levindo acreditava na revolução como forma de fortalecer os oprimidos enquanto Nando defendia os índios pela catequese em Cristo,

- Me ajude, Padre Nando - disse Levindo. - O que eu quero dizer ao Leslie é que precisamos criar dentro do brasileiro a ajuda ao Brasil, Temos de fabricar os mitos.

- Você se interessa pelos índios - disse Nando.

- Não - disse Levindo - não me interesso pelo índio assim feito você, isto não. Nada de missões e parques indígenas. Só nos países onde os homens vivem direito é que jardins zoológicos podem funcionar. $\mathrm{O}$ índio por enquanto que se defenda. (CALLADO, 1984, p.33)

No capítulo "A Orquídea”, marcado pela busca ao "centro" geográfico do país, é que temos as cenas mais fortes e representativas da narrativa. Nesse momento do romance Nando não é mais padre e há a consumação de seu amor com Francisca em um paraíso em meio às orquídeas. Contudo, também é nesse capítulo que ocorre o trágico fato do crean acárore, em que uma tribo é dizimada pela epidemia de sarampo e disenteria trazida pelo homem branco. Um momento da narrativa extremamente trágico que nos é narrado por narrador e personagens de forma grotesca, como podemos observar nos seguintes trechos:

Adiantaram-se pelo acampamento adentro cambaleantes e foram aos jiraus enfiando na boca a comida e a farinha e o arroz que encontravam e outros vieram e em pouco tempo o que havia de comida tinha sumido.

- Famintos! - disse Fontoura.

- Mas não é só isto - disse Vilaverde. - Estão morrendo de alguma outra coisa também. (CALLADO, 1984, p.356)

(...)

Um cren meio morto, de olho revirado, ia se afastando de quatro para o mato mais perto mas não teve tempo de chegar e se aliviou assim mesmo, joelhos e mãos no chão, e ali ficou de rabo pingando, olhando Ramiro e Olavo que se afastavam carregando os rifles.

- Como fazem cocô! - disse Olavo.

- Estes índios realmente exageram na disenteria - disse Ramiro. (CALLADO, 1984, p.361)

A história do chefe cren era que o pajé tinha dito que sabia mas não sabia curar doença trazida pelos brancos. Então os cren tinham assassinado o pajé e não tinham outro à mão. (CALLADO, 1984, p.363)

$(\ldots)$

Eles estão na última lona. Vi mortos praticamente em todas as malocas. Acho que até alguns dos que estiveram aqui voltaram para morrer. Estavam quentes ainda. (CALLADO, 1984, p.364) 
Nesses trechos destacados o que percebemos são os relatos grotescos sobre a trágica situação de extinção que os índios sofreram após o contato com os seringueiros e a morte do pajé. Tendo em vista que o pajé é assassinado por não conseguir conter a disenteria, podemos avaliar esse fato simbolicamente como a denúncia da negação dos valores, costumes e credos indígenas.

Para Cristiane de Assis Portela (2008),

A história indígena no Brasil foi marcada pela imposição de uma unidade nacional que excluía a diversidade e "lembrava", sob diferentes formas de violência, que índios deveriam deixar de ser índios. Na contemporaneidade, as formas de violência persistem, a despeito dos avanços jurídicos conquistados pelos movimentos indígenas nas últimas décadas do século XX. Porém, no âmbito do imaginário nacional, há inúmeras ideias estereotipadas que foram consolidadas historicamente (PORTELA, 2008, p. 151).

Quarup ainda mantém alguns desses estereótipos atribuídos aos índios, além de se afastar da construção estética do índio romântico quando o percebe por um viés grotesco, ridiculizador, oportunista. Quando a expedição sai rumo ao centro do Brasil - no capítulo "A Orquídea" - Ramiro encontra cartazes de um filme que seria feito sobre Sônia que fugiu pela floresta com o índio Anta. Ramiro encontra com um grupo de indígenas que possuem informações sobre Sônia, mas que para que digam algo impõem uma troca de presentes como pagamento,

Movido talvez pelo açodamento de Ramiro os txucarramãe não o levaram logo à cabana da mulher branca. Ramiro teve de dar como presente a eles até as duas camisas engomadas que ainda guardava. (CALLADO, 1984, p.315)

É a representação do índio interesseiro completamente inteirado das operações de troca e comércio, visando à própria necessidade, do mundo dos homens brancos. Ainda durante a expedição e a busca por Sônia podemos observar, no trecho abaixo, a construção feita por Callado para perceber o entendimento de selvagens, exóticos e perigosos dos indígenas,

- Você pensou que fosse Sônia, meu bem? - disse Nando. - Ah, que impressão terrível, Nando. Tolice minha, é o escuro da maloca. Mas pensei por um momento que a vida selvagem, ou os sofrimentos não sei, tinham transformado ela. Ainda sinto um arrepio, sabe? Como estará Sônia, a verdadeira Sônia? O que acontece se a gente viver durante anos essa vida deles? - Eu duvido que dure muito tempo, Francisca. (CALLADO, 1984, p. 316 , grifo meu) 
É, portanto, o receio de Francisca que revela na narrativa a visão estereotipada dos índios selvagens que corrompem a civilidade e os princípios do homem branco.

Dessa forma, Quarup ainda que se distancie da visão do ancestral bon sauvage desenvolvida por Alencar, ainda possui os discursos em defesa do povo indígena sem que nenhum deles seja, de fato, o do índio. Segundo Ávila (1983, p. 364), “o nativo não chega a 'merecer' uma forma estética nobre. $\mathrm{O}$ grotesco denuncia agressivamente as injustiças, mas não suscita qualquer sentimento de simpatia". Outro exemplo dessa percepção exterior sobre o índio diante da degradação do autóctone com o contato com o home branco, é a que trata da doença de Aicá,

- O que é que tem esse índio?

- Venha ver. É parte do seu mistério.

[...]

De uma rede na penumbra levantou-se um rapagão dos seus vinte e poucos anos. Parecia em tudo e por tudo qualquer dos índios do acampamento que Nando vira até agora. Lídia tirou do bolso um embrulho.

- Para Aicá - disse ela.

O índio se aproximou da caixa de anzóis e linha de pesca que lhe trazia Lídia. Então Nando viu como estava coberto de feridas. Jó tinha muito mais anos do que Aicá, pensou Nando, mas não pode ter tido mais chagas..

- Aicá está assim há bem uns dez anos - disse Lídia. - Fogo selvagem.

- Fogo selvagem. - repetiu Aicá, familiarizado com o nome dado pelos brancos para à sua moléstia.

$[\ldots]$

- Deus me livre achar que Aicá não sofre, mas sofrerá como um de nós? Com a mesma sensibilidade? E com o mesmo horror da chaga em si e da chaga vista pelos outros? (CALLADO, 1984, p. 236)

Esses episódios, assim como outros na narrativa mostram-se como a forma encontrada por Callado para revelar e desconstruir a ideia do índio perfeito que resiste belo, forte e corajoso à invasão do homem branco, além de revelar o olhar desumanizador que o homem "civilizado" lança para o indígena. Desse modo, a literarização do indígena em Quarup reconhece que a condição de atraso não é passageira ou meramente circunstancial e por isso a obra de Callado resulta em um negativismo, uma vez que mesmo superando questões do indianismo a obra confirma que o índio ainda permanece como um problema para o Brasil. Portanto, o índio representado no século XX deixa de ser o índio romântico com costumes e valores europeus e passa a ser construído como aquele que necessita ser salvo de sua ignorância e da ganância destruidora do homem branco. Dessa forma, para Leite (1982, p. 15), "a pastoral indígena nasce da exigência de resgatar o índio como ser social, o qual, salvo poucas exceções, é tido como "coisa". A narrativa assimila esse projeto missionário, em pleno curso na série social". 
Ao questionar o sofrimento do índio Aicá, tendo dúvidas se o sofrimento do indígena é o mesmo do homem branco, o que temos é o olhar desumanizado para o outro que o retira da condição de "igual”, ao qual, de fato, ele nunca esteve. Tal construção nos leva a refletir, extrapolando o indianismo, sobre o sentimento de existência incompleta que está no índio, mas que também está nos mestiços, nos nordestinos, nos migrantes e em todas as pessoas que se apresentam em uma situação marginal na nossa sociedade graças ao nosso hostil processo colonizador.

Dessa forma, para Lukács (1970, p. 262),

O particular como categoria estética abraça o mundo global, interno e externo. (...) O universal, por seu turno, é tanto a encarnação de uma das forças que determinam a vida dos homens, como ainda um veículo de vida dos homens, da formação da sua personalidade e do seu destino. Com esta representação simbólica do singular e do universal, a obra de arte revela em virtude da sua essência objetiva, independentemente das intenções subjetivas que determinaram o seu nascimento - uma qualidade interna, em si significativa da vida humana, terrena.

Seguindo em nossa análise por capítulos temos o terceiro capítulo de Quarup, intitulado "A Maçã”, que inicia com uma representação às avessas do episódio bíblico entre Adão e Eva,

Estava Nando a uns vinte metros quando de dentro da casa saiu um casal de índios. Um belo casal de índios. Se primeiro casal de índios. Nus. Ela apenas com seu uluri, ele apenas com um fio de miçangas na cintura. Deram dois passos para fora da casa. Voltaram-se um para o outro. Nando, que estacara, viu então que a mulher tinha na mão direita uma maça, que oferecia ao companheiro. O índio fez que não com a cabeça. Ela mordeu a maça. E então, virando-se para Nando, foi lentamente andando em sua direção, a maça na mão estendida em oferta. Nando confuso, pôs a mala no chão, estirou a mão. (CALLADO, 1984, p. 153)

Este capítulo, diferentemente dos dois primeiros, não se centra em Nando e seus projetos utópicos, mas é o desvelamento do espaço do outro para o jovem padre. É, portanto, em "A Maçã" que Nando perceberá como seus projetos para os índios se demonstram esvaziados de sentidos diante da realidade devastadora em que os indígenas se encontram, em face ao contato com o homem branco, pois, segundo Robeni B. Mammizuka (1983, p. 43-44),

a ideologização do índio, marcando-o negativa ou positivamente, ocorre, dado que as personagens assumem o desconhecimento da realidade (...) ainda que tenham discutido a realidade indígena, mas na busca da correspondência entre o modelo e o índio real, aquele saber se desmancha. Este saber se desmancha exatamente porque foi construído a partir de preconceitos e clichês. 
$\mathrm{Na}$ reconstrução do protagonista, Nando, se desprende do sacerdócio "É a primeira vez que eu te vejo com roupa... - De homem - disse Nando" (CALLADO, 1984, 170) e aprende a se comunicar e a viver com os índios,

Em longas caminhadas de beira-rio, em visitas aos índios camaiurá acampados à beira do lago, embrenhando-se na mata pra ver um veado correndo na distância ou garças voando reto como flechas brancas disparadas das copas das árvores, Nando ruminava o plano e triturava nomes com fervor. Takuxirrae, suiá, txucarramãe, iarumá, miarrã. (CALLADO, 1984, p. 167)

É em "A Maçã” que temos a preparação para o quarup. Neste momento todos vivem a expectativa da chegada de Getúlio e do Ministro Gouvéia, até mesmo Fontoura que acreditava que o contato dos índios com os homens brancos era o veredito de sua dizimação via na chegada de Getúlio a concretização da criação do Parque. O que nos interessa é perceber que este momento é construído de forma a ressaltar as discrepâncias entre dois mundos tão distintos e em como o contato do homem branco com o índio retira sua identidade. Para exemplificar isso analisaremos o trecho abaixo, em que Fontoura explica a necessidade da colaboração de todos na preparação do quarup,

- Não- disse Fontoura - você não vai me tirar ninguém daqui antes do quarup. Padre Nando, Otávio, Lídia, até o Ministro se eu pegar ele de jeito vão ajudar na pesca. Senão esses índios convidam os mil índios do Xingu e quando chegarem aqui não tem comida pra cem.

[...] - Mas são uns mandriões, esses teus índios - disse Vilar. - Nem para dar de comer aos convidados conseguem trabalhar feito gente.

Fontoura emburrou.

- Quando eles tinham as terras férteis de outrora davam seus quarups com facilidade. Depois de séculos de exploração e de roubos dos civilizados precisam da nossa ajuda para recuperarem os hábitos e a alegria de outrora. Nem tudo é fazer cidade e abrir estrada. (CALLADO, 1984, p. 186)

O que Fontoura tenta explicitar é a condição de dependência em que estão os índios em relação aos homens brancos. Isso porque ao entrar em contato com o homem branco já não eram mais inteiramente índios, eram qualquer coisa que necessitavam de ajuda e proteção "ensinando os índios a se manterem selvagens" (CALLADO, 1984, p. 187). Não que surta efeito a defesa de Fontoura, pois a intromissão do ritual acontece, feita por Vilar, como veremos,

Vilar transformava o trabalho do quarup numa espécie de violento folguedo. [...] Vilar foi buscar a lenha da derruba no campo de pouso e pôs-se a desbastar os paus para fazer dezenas de moquéns para moquear milhares de peixes. [...] Os jiraus do moquém afogueados pelos brasileiros transbordaram 
do terreiro, se esparramaram pelas cercanias. As tribos recém-chegadas davam sua mãozinha aos anfitriões. Cuias de caxiri circularam. Mulheres puseram-se a dançar em fila. E voltava Vilar segurando pela proa, acima da cabeça avermelhada pelo fogo, uma ubá com os últimos peixes, segurada na popa por Saruiá. [...]- Este não é o espírito em que eles se preparam para uma festa religiosa como o quarup - disse Fontoura. - Trabalham até a festa, exatamente no preparo da festa. Se você fizer tudo está roubando deles o espírito do quarup. (CALLADO, 1984, p. 229-230)

Este momento da narrativa é antes de tudo a constatação da complexa e diversificada sociedade brasileira - reconhecimento que não existia no romantismo, por exemplo - pois, com a chegada do núcleo de personagens do Rio de Janeiro podemos perceber os diferentes interesses entre índios e homens brancos. Fontoura é o ser que permanece entre esses dois polos tentando preservar o máximo, que é o mínimo, do quarup.

Não podemos deixar de mencionar que é em "A Maçã” que acontece de forma clara a fusão entre plano ficcional e plano histórico, estratégia bastante conhecida por Callado e que explicitamos no capítulo anterior. No Rio de Janeiro estava a tensão política e no Xingu a festa do quarup é, pois, durante o ritual que recebem a notícia da morte de Getúlio,

Os índios de huka-huka e do moitará e javari só ouviram porque conheciam muito bem a voz de Fontoura mas ligar não ligaram o grito dele não, porque não queria dizer nada que índio soubessem e viram logo que só podia ser coisa entre caraíba o Fontoura berrando o velho se suicidou, o velho se matou, o velho morreu e nem interessava também que o Cícero berrasse junto dizendo meteu bala no coração e morreu, Getúlio morreu. Otávio saiu correndo como um doido do campo de pouso e encontrou diante da casa do Posto Cícero aos soluços e Fontoura repetindo Getúlio morreu e Nando e Vanda e Lídia de caras transformadas também [...]. (CALLADO, 1984, p. 332)

$\mathrm{E}$, enquanto isso, os índios seguiam desfazendo de seus quarups, encerrando o ritual, "quarups que vinham rolando, rolando pelo declive tocados pelo pajé e plaf plaf plaf um atrás do outro entrando n'água e o maior de Uranaco mergulhou um pouco, emergiu, saiu boiando" (CALLADO, 1984, p. 332).

Para avaliar analogamente a discrepância entre o verdadeiro ritual do quarup e o da narrativa acreditamos ser necessário situarmos o ritual indígena que inspira o livro. Kuarup é o nome dado a uma cerimônia de celebração da vida e da morte realizada pelos índios da região do Alto Xingu. Sobre a lenda que teria dado origem a esse cerimonial Villas-Bôas (2000, p. 7778) esclarece que,

(...) o lendário Maivotsinin, auxiliado por Ianamá, outra figura lendária, saudoso de sua gente desaparecida num passado remoto, resolveu criar outras gentes. [...] Maivotsinin e Ianamá assentaram que seriam seis os 
casais a serem criados, feito isso, plantaram na praia os doze toros. Noite alta, os toros começaram a tremer de frio, e os dois heróis lendários fizeram fogo ao pé de cada um. A esperança era de que o calor do fogo e a força criadora Maivotsinin os transformassem em seres humanos. Postado atrás do Kuarup, o herói criador cantava e agitava seu maracá. A noite e a madrugada avançaram e os toros continuaram rijos. (...) Aos primeiros raios do sol da manhã, os fogos foram retirados de perto dos Kuarups. E o calor do sol começou a dar vida aos toros plantados. Os peixes alegres saltaram dos rios para homenagear as criaturas. A onça, imitando-os, correu para a praia e começou a lutar com os peixes. Maivotsinin, num gesto, transformou todos em índios 'camará' (comuns), já que aqueles criados eram ligados à linhagem do criador. É por isso que hoje só se justifica o Kuarup quando morre um índio dessa descendência. Os índios comuns (camarás) podem, no entanto, aprontar um Kuarup para prantear seus mortos. Terminado o cerimonial, os toros perdem seus enfeites e são lançados na parte funda de uma lagoa ou de um rio.

Contudo, além da celebração de um morto a cerimônia também pode ter sentido de ressureição. Podemos, assim, observar na obra de Callado o desejo do escritor de marcar que há renovação após o quarup, é também a concretização do projeto dele para o país revelando a necessidade de integração do passado com o presente para transformações significativas. Ao analisarmos estritamente o ritual podemos observar o sentido de renovação da vida nos toros de madeiras esculpidos e pintados que foram lançados nas águas do rio, ressaltando sua simbologia de renascimento. É também depois do quarup que Nando deixa de lado seus projetos utópicos e o sacerdócio e passa a encarar seus medos, como o temor de ver as índias nuas. Este se perde ao perceber a naturalidade dos índios Combra e Auaco,

Distraídos, olhando ora para o lado de Lídia ora para o lado de perna de Combra, cuja mão ficou sobre seu ombro esquerdo. Combra, alerta, esquadrinhava tudo com os olhos. Auaco, linda, sonolenta, olhava em frente. A mão de Combra estava naturalmente na altura do seio esquerdo de Auaco e ele começou a acariciá-lo. Era impossível a Nando não olhar disfarçadamente a estranha cena, que Lídia sem dúvida olhava também. Dois jovens índios, noivos ou lá o que fosse, nus em pelo, ele acariciando o peito dela e, no entanto, ela quase adormecida e ele olhando as modas ao redor, sem dar o menos sinal de excitação. (CALLADO, 1984, p. 173)

A simbologia do ritual quarup perpassa toda a narrativa norteando mudanças e renovações não só em Nando, mas também em outros personagens como, por exemplo, quando a personagem Sônia - prostituta russa - resolve se deitar e em seguida fugir com o índio Anta, a personagem, por sua vez, se despe não só de roupa, mas também de sua cultura aprendendo um novo jeito de viver,

Sônia tirou o vestido pelos ombros, depois o resto da roupa e sentiu um gostoso arrepio pela incuriosidade que sua nudez despertava. Será que os índios não iam falar naquilo? Mulher branca em rede de índio devia valer pelo menos uma fofoca xinguana. Mas ali estava ela nua em pelo no meio da 
maloca diante de homens e mulheres e todo o mundo continuava balouçando em rede de buriti, dormitando, esfregando tinta no corpo [...] Sônia entrou na rede do Anta feito fêmea índia e deixou ele deitar em cima e pensou que só queia estar ali na maloca com um homem desencrencado por cima e que era só isso [...] (CALLADO, 1984, p. 244)

Neste momento da narrativa podemos marcar uma diferença explícita entre a representação do índio romântico e a de Callado. O índio Anta, que já retratamos anteriormente, identificado sobre o estereótipo do índio preguiçoso em nada se assemelha ao “cavalheiro medieval” que foi Peri, em Guarani, de José de Alencar. A impossibilidade do romance entre Peri e Cecília e, portanto, entre um índio e uma mulher branca desenvolvida no século XIX já não existe entre Sônia e Anta, certamente, devemos guardar as distinções entre Cecília, a jovem donzela, e a prostituta Sônia. Todavia, ainda está presente a ideia de que a vida plena é a vida selvagem, primitiva e ingênua que vive longe da promiscuidade do mundo do homem branco, o que não deixa de ser uma homologia com a obra de Alencar.

O quarto capítulo "Orquídea" é, de forma resumida, o momento da Expedição e a chegada ao centro do Brasil. Nesse capítulo que Nando reencontrará Francisca, após sete anos, e será através dela e da admiração do trabalho de Levindo que Nando encontrará seu destino. Neste sentido, a expedição ao centro do Brasil pode ser vista como o quarup de Nando, ao encararmos ela como um ritual de "morte", já que é neste momento da narrativa que ele deixará de ser padre e se transformará no ativista em defesa de causas sociais que sem hesitação irá manejar armas e provocar revoluções em busca de transformação.

Cada integrante da expedição possuía propósitos distintos. Para Francisca o desejo era de registrar a viagem e cumprir a promessa feita à Levindo, de levar um punhado de terra do centro do Brasil - Levindo tinha sido morto por um tiro há, aproximadamente, dez anos sem nenhuma investigação ou reconhecimento por seus anos de luta. Ramiro era motivado pelo desejo de reencontrar Sônia que havia fugido com o índio Anta. Vilaverde, que mais tarde assumiria o posto de Fontoura no SPI, admirador de Rondon, empenha-se na construção do Parque e auxilia durante a expedição no contato com as tribos violentas, suiá e os txucarramãe, além dos doentes cren-acárore. Na expedição ainda há o sociólogo e etnólogo Lauro que é marcado na narrativa por ter seus conhecimentos limitados a teoria.

Mesmo com todas as dificuldades a expedição chega ao Centro Geográfico do Brasil, na cena, sem dúvidas, a mais trágica e simbólica de Quarup. Fontoura que se constitui na narrativa como um herói as avessas que lida com o alcoolismo e suas limitações diante da 
luta incessante de resguardar os índios e sua cultura do avanço devastador do homem branco morre com o rosto em um formigueiro de saúvas buscando ouvir o coração do Brasil,

Trêmula, segurando forte o braço de Fontoura, Francisca foi andando para perto do padrão. A poucos metros da rede sentiu um arrepio de aflição ouvindo as formigas que estouravam pisadas pelos dois. [...] Quando chegaram ao pé do padrão Fontoura pôs os joelhos no chão e leu:

- Centro Geográfico do Brasil, latitude dez graus e vinte minutos sul, longitude cinquenta e três graus e doze minutos oeste de Greenwich.

Fontoura caiu de cara no chão, as mãos para a frente, o ouvido colado à terra enquanto inquietos bandos de formiga lhe cobriam os dedos e o pescoço. [...]

- Ponha o seu ouvido na terra - disse Fontoura.

- Para quê? Levanta!

Mas na impossibilidade de erguer Fontoura Francisca se curvou, deitou o rosto sobre as formigas enlouquecidas, sentiu viva e feroz a terra de Levindo.

- Está ouvindo? - disse Fontoura.

- O quê?

- O coração. (CALLADO, 1984, p. 377)

A morte de Fontoura e o formigueiro de saúvas encontrado no centro do Brasil revelam a desesperança e o fracasso da tentativa de salvação dos índios, mas, além disso, são também a constatação da frustração diante da missão de resgatar o começo do território brasileiro e atribuir a ele uma nova gênesis. A expedição buscava, na verdade, conceituar o Brasil redefinindo, ou ainda, definindo a identidade brasileira.

Na perspectiva em que direcionamos este trabalho - isto é, de encarar a literatura como possibilidade de investigação e descoberta do Brasil - podemos considerar a explosão do grande formigueiro de saúvas como a desesperança e impossibilidade de um futuro unificado e justo da reconciliação com os povos indígenas, pelo menos, naquele momento. Neste sentido, torna-se ainda mais simbólico quando os integrantes da expedição esquecem a bandeira que seria fincada no Centro, a explicitação da incompletude, "de longe os membros da expedição e os da turma de socorro viram que tremulava ao vento, no pau da bandeira, um pano cor-de-rosa com florões rosa." (CALLADO, 1984, p. 380). 
O título do quinto capítulo, "A Palavra", se justifica pela importância da palavra no processo de alfabetização, que se revela como parte de um processo de desalienação. Para Leite (1982, p.23), Quarup se move nos

princípios dos Centros Populares de Cultura, de uma arte engajada e mobilizadora, do romance realista lukacsiano, o conceito da conscientização, bebido na pedagogia de Paulo Freire, os princípios isebianos de Cultura Nacional, modernização e consciência nacional. É isso que se busca e é isso que se lê em Quarup.

Neste capítulo são abordadas questões como a Liga dos Camponeses, a criação dos sindicatos e a luta da esquerda brasileira. Na volta ao Pernambuco o Nando pós-quarup se apresenta como um militante consciente e seguro de suas convicções e ideais e muito otimista com o momento político do país,

'- Meu reino de Deus foi adiado - disse Nando. - Por pouco. Em nenhum lugar do mundo o mundo está sendo tão rapidamente alterado e tornado melhor como aqui, neste ponto do Brasil, neste momento. E eu estou dentro do turbilhão. Sou uma faísca do raio. Quando além disto eu tiver Francisca vou viver ao mesmo tempo neste turbilhão e na realidade. (CALLADO, 1984, p. 397)

No entanto, este otimismo dura pouco e paira a frustração do sonho utópico de igualdade e justiça social. A esperança de tempos melhores dá lugar às torturas do período da ditadura militar. Nando é preso. Este capítulo, então, encerra com mais uma vez o protagonista tendo que encarar uma reconstrução, tendo em vista, que descobre que Francisca voltara para Europa e o mundo que idealizavam se encontra mais distante do que nunca. O capítulo "A Praia" é o retorno de Nando para si mesmo, sem buscar por revoluções insere-se em experiências sexuais convencido de quem ensina sobre o amor e como amar.

Decidido a fugir do país Nando organiza um jantar em homenagem a Levindo cheio de referências ao quarup dos índios do Alto Xingu. No jantar comeram "o fruto das pescarias e mariscagens de Amaro, Zeferino, Quimango e Margarida, das ostras e lagostas e lagostins à traíra cor de salmão" (CALLADO, 1984, p. 549-551), receberam convidados “juntou gente na porta da casa de Nando para ver a chegada dos convidados". Na hora do jantar Nando propõe um brinde,

- Estamos aqui reunidos em espírito de festa para lembrar o único brasileiro morto em luta por uma idéia. Brasilidade é o encontro marcado com o câncer. Brasilidade é a espera paciente da tuberculose. Brasilidade é morrer na cama. À frente de um grupo de camponeses, morrendo pelo salário do camponês, Levindo morreu uma bela morte estrangeira. Estamos hoje aqui 
para comer o sacrifício de Levindo, comer sua coragem e beber seu rico sangue de brasileiro.

O excerto acima, notoriamente, revela semelhanças do ritual indígena do quarup, mas também aspectos do ritual antropofágico realizado pelos índios tupinambás que comiam a carne e bebiam o sangue do índio da tribo vencida para que se apropriassem de suas qualidades. Também podemos comparar este momento da narrativa a última ceia celebrada por Cristo, em que Nando assumiria o papel do sacerdote que realiza tal cerimônia,

Tomou em seguida o pão e depois de ter dado graças, partiu-o e deu-lho, dizendo: 'Isto e o meu corpo, que e dado por vos; fazei isto em memoria de mim'. Do mesmo modo tomou também o cálice, depois de cear, dizendo: 'Este cálice e a nova aliança em meu sangue, que e derramado por vos...' (LUCAS 22:19-20).

De certo, Cristo morre em sacrifício aos pecadores, já Levindo teria dado seu sangue em sacrifício na luta pelos camponeses. Continuando nesta análise comparativa precisamos destacar que, diferentemente, do quarup que homenageia Uranaco, o líder de uma sociedade que existia e que lutava para que continuasse a existir de forma inteira, Levindo é o herói de uma sociedade que necessitava da luta para que um dia pudesse existir.

Analogamente, durante o jantar, Nando é informado que a Marcha ${ }^{23}$ se aproxima do centro da cidade, portanto, mais um momento da narrativa que explicita a impossibilidade da construção da nação. Dessa forma, concluímos que o ritual do quarup não é um momento isolado da narrativa no terceiro capítulo, pelo contrário, ele assume no romance a centralidade temática irradiando a partir dele e de sua essência aborígene questões que perpassam senão todos, a maioria dos personagens e a história brasileira daquele momento. Ao que conferimos um refinamento da técnica narrativa desenvolvida por Callado que se apresenta como um elemento central para superação do indianismo e universalização da obra,

O que vemos agora, sob este aspecto, é uma florada novelística marcada pelo refinamento técnico, graças ao qual as regiões se transfiguram e os seus contornos humanos se subvertem, levando os traços antes pitorescos a se descarnarem e adquirirem universalidade. Descartando o sentimentalismo e a retórica; nutrida de elementos não-realistas, como o absurdo, a magia, das situações; ou de técnicas antinaturalistas, como o monólogo interior, a visão simultânea, o escorço, a elipse - ela implica não obstante em aproveitamento do que antes era a própria substância do nativismo, do documento social. (CANDIDO, 2006, p. 195)

\footnotetext{
${ }^{23}$ A Marcha da Família com Deus pela liberdade foi uma sequência de manifestações públicas que ocorreram no período entre 19 de março e 8 de junho de 1964. Essa Marcha foi idealizada e promovida por uma elite que via as medidas tomadas por João Goulart como uma "ameaça comunista".
} 
Por abordar tantas temáticas, Quarup é construído de forma a constituir um "retrato do Brasil ${ }^{24}$ ". Em uma primeira análise podemos perceber uma composição quase plástica, se considerarmos as diversidades de elementos representados na composição da criação dos personagens e seus pontos de vista sobre o Brasil e seus problemas. Contudo, nesta pesquisa observamos que o romance supera a plasticidade do "retrato" através do enredo que liga os personagens e o conteúdo histórico que entrelaça os personagens e suas ações. Por isso, nossa análise de Quarup põe em movimento os elementos constitutivos do retrato brasileiro incorporando na obra elementos como a problematização histórica da nossa formação, a questão do indígena e a desesperança do momento em que foi escrito, além de trazer em si a herança de uma tradição literária que desde o início deste trabalho buscamos explicitar.

Antonio Callado consciente da impossibilidade de retratar o índio ignorando o processo violento da colonização e o desprezo com que foi tratado durante toda a história constrói uma obra que se utiliza do elemento estético indígena para destacar os problemas da formação do país. Neste sentido, em Quarup, não há a exotização do índio, mas o compromisso de Callado é com a sua figuração histórica, por isso não cabe em sua narrativa nem o humor, nem a sátira e a ironia.

\footnotetext{
24 No livro Quando a pátria viaja : uma leitura dos romances de Antonio Callado, da escritora Ligia Chiappini, há um esclarecimento sobre o termo "retratos do Brasil" utilizado várias vezes em entrevista pelo escritor Antonio Callado ao se referir a Quarup. Tal termo diz respeito ao ensaio impressionista de Paulo Prado sobre a formação étnica do Brasil que foi publicado em 1928.
} 


\section{CONSIDERAÇÕES FINAIS}

Neste trabalho, nos concentramos em acompanhar a tradição literária brasileira que trata do índio tendo como ponto de chegada o romance Quarup, de Antonio Callado. Tal tradição, como tentamos mostrar, é superada pela obra de Callado não pela mera negação dos elementos estéticos tradicionais do indianismo, mas porque Quarup se mostra capaz de tornar visível a realidade em sua dimensão histórica e, portanto, contraditória. Ao trazer para narrativa vários personagens, dos mais diferentes planos e com as mais variadas intenções e pretensões, o autor torna possível a configuração das mais diferentes percepções e interesses dos personagens sobre o índio.

Para chegarmos a esse ponto buscamos, também, entender e compreender a questão da literarização do elemento indígena desde os primeiros relatos dos cronistas e viajantes sobre os índios que viviam por aqui no período da colonização. Compreender os efeitos da colonização em sua dimensão histórica e em como isso reflete em nossa literatura se tornou imprescindível para nossa análise que priorizou o princípio estruturante de Antonio Candido (2000a), considerando que a história é um elemento estruturante da obra literária.

No segundo capítulo tornou-se necessária a retomada do indianismo para que pudéssemos no quarto capítulo realizar a aproximação entre a obra de Callado e a tradição romântica. No entanto, acreditamos que quando esta aproximação acontece, em um jogo dialético de negação e reafirmação dessa tradição, Quarup se torna consciente das contradições históricas do país.

Além dessas questões, discutimos a influência do engajamento de Callado, enquanto jornalista, em suas obras literárias considerando a noção de empenho, desenvolvida por Antonio Candido (2009), levantando e analisando aspectos do contexto social e literário do Brasil do século XX. Apontamos aproximações entre fato e ficção nas produções do escritor e em como sua trajetória social e convicções resultam em um projeto literário voltado à práxis social na construção de obras que buscavam reconstruir e organizar a história social e política do país, como esclarece o autor em entrevista concedida a Marcelo Ridenti, em 1996,

A única coisa que me interessou durante esse tempo todo, da minha formação e do meu trabalho, foi exatamente a possibilidade de uma re-vo-lução que mudasse o estado de espírito de um país como o Brasil (...). (CALLADO apud RIDENTI, 2002, p. 36) 
Por fim, no quarto capítulo, analisamos Quarup buscando compreender que ainda que esta obra possua traços da tradição romântica, revelando um processo contínuo entre obras de períodos tão diferentes da nossa literatura, ela é capaz de nos fazer analisar a questão do índio de uma forma mais crítica e consciente das consequências do processo colonizador e devastador - ainda sem solução - para os povos indígenas. É, portanto, através da trajetória de Nando que percebemos o posicionamento político e ideológico de Antonio Callado.

Quarup revela, pela temática do renascimento - materializada na cerimônia do quarup - o desejo de Callado de reinventar o Brasil, inicialmente na utopia da comunidade modelo do homem "civilizado" idealizada por Nando até sua incorporação de Levindo, na última cena. Ainda que não consiga se desvencilhar do pessimismo e do sentimento de impotência daqueles anos de ditadura há sempre uma possibilidade de transformação por vir.

Chegamos ao fim deste trabalho com a certeza de que há ainda muitas questões que Quarup e a literarização do índio nos impõem e que não puderam ser contempladas. Dessa sensação de incompletude e da necessidade de fazer perguntas de uma forma ampla que inclua, por exemplo, o índio não só no contexto brasileiro, mas também no da América Latina a partir da perspectiva que transforma o índio em elemento estético para pensar a identidade nacional nos desafiaremos em um novo passo da trajetória acadêmica. Assim, pretendemos posteriormente no doutorado analisar de forma análoga o indianismo brasileiro e o indigenismo peruano através das obras de Antonio Callado e de José Maria Arguedas.

Concluimos, portanto, que Quarup é um romance da busca. Quando o padre Nando vai ao centro do Brasil desenvolver uma comunidade ideal com os índios está impressa a necessidade de reconstruir uma história que fracassa pela constatação da dizimação dos povos indígenas desde o processo colonizador. A temática do centro se apresenta como o desejo necessário de equilíbrio e reformulação do país, levantando questões antigas e inacabáveis "em virtude da concentração, seleção, densidade e esterilização do contexto imaginário, que reúne os fios esfarrapados da realidade” (CANDIDO, 2005, p.35) 


\section{REFERÊNCIAS BIBLIOGRÁFICAS}

ALENCAR, J. de. O Guarani. São Paulo: Ática, 1998a.

Iracema. São Paulo: Ática, 1998b.

Ubirajara. São Paulo: Ática, 1999.

Como e porque sou romancista. Rio de Janeiro: Pontes, 2005.

A Confederação dos Tamoios (excertos). In: COUTINHO, A. (org.). Caminhos

do pensamento crítico. Rio de Janeiro/Brasília:

U Pallas/Instituto Nacional do Livro, 1980.

ANCHIETA, J. de. Cartas: informações, fragmentos históricos e sermões. Belo Horizonte-Itatiaia-São Paulo: Edusp, 1988.

ANCHIETA, José S. J. Poesias. Manuscrito do século XVI, em português, castelhano, latim e tupi. Tradução: Maria de Lourdes de Paula Martins. São Paulo: Comissão do IV Centenário. 1954.

ANDERSON, B. Comunidades imaginadas. Reflexões sobre a origem e a expansão do nacionalismo. Lisboa: Edições 70, 2012.

ARRIGUCCI JR., D. Jornal, realismo, alegoria: o romance brasileiro recente. In: Outros achados e perdidos. São Paulo: Companhia das Letras, 1999.

ASSIS, M. de. Obra completa em quatro volumes. v. 3. Rio de Janeiro: Nova Aguilar, 2008.

ÁVILA, H. M. E o verbo se fez carne: uma introdução à teoria do realismo crítico e sua aplicação à leitura do romance Quarup de Antonio Callado. 1983, 400 f. Dissertação (Mestrado em Teoria Literária) - Universidade Federal do Rio de Janeiro - UFRJ, Rio de Janeiro, 1983.

BAKHTIN, M. Estética da Criação Verbal. São Paulo: Martins Fontes, 2015.

BASTOS, A. O índio antes do indianismo. Rio de Janeiro: 7 Letras: FAPERJ, 2011.

A Bíblia Sagrada: Tradução na linguagem de hoje. Barueri: Sociedade Bíblica do Brasil, 2012.

BRANDILEONE, A. P. F. N. O Romance-Reportagem: Implicações EstéticasIdeológicas. Revista de Estudos Literários. v. 19, 2010.

BOSI, A. Dialética da colonização. São Paulo: Companhia das Letras, 1992.

CAlladO, A. A expedição Montaigne. 2.ed. Rio de Janeiro: Nova Fronteira, 1982. Quarup. 14.ed. Rio de Janeiro: Nova Fronteira, 1984. 
Tempo de Arraes - a revolução sem violência. Rio de Janeiro: Paz e Terra, 1979.

CASTRO, S. A carta de Pero Vaz de Caminha: O descobrimento do Brasil. Porto Alegre: L\&PM, 2014.

CANDIDO, A. Formação da literatura brasileira: momentos decisivos. 3.ed. v. 2. São Paulo: Martins, 2009.

Movimento e parada. In: Na sala de aula. São Paulo: Ática, 2004.

Letras e ideias no período colonial e Estrutura literária e função histórica. In:

Literatura e sociedade. 9.ed. Rio de Janeiro: Ouro Sobre Azul, 2006a.

Literatura de dois gumes. A educação pela noite. Rio de Janeiro: Ouro Sobre Azul, 2006b.

O Romantismo no Brasil. São Paulo: Humanitas/FFLCH, 2002.

Vários escritos. 5.ed. São Paulo: Ouro Sobre Azul, 2011.

COELHO, J. M. Em nome da consciência. Revista Veja. jul. 1976

DENIS, Benoît. Literatura e engajamento: de Pascal a Sartre. São Paulo: EDUSC, 2002.

DURÃO, José de Santa Rita. Caramuru: poema épico do descobrimento da Bahia. São Paulo: Martin Claret, 2003.

Guanabara. Revista Mensal Artística, Científica e Literária. Rio de Janeiro, 18491851, 1854-1856.

GAMA, B. da. O Uraguai. Rio de Janeiro: Record, 1998.

GRAÇA, A. P. Uma poética do genocídio. Rio de Janeiro: Topbooks, 1998.

GULLAR, F. Quarup ou ensaio de deseducação para brasileiro virar gente. In: Revista Civilização Brasileira. ano III, n. 15, set. 1967.

IANNI, O. Nação e narração. In: AGUIAR, F. (org.). Antonio Candido: pensamento e militância. São Paulo: Fundação Perseu Abramo: Humanitas/ FFLCH/USP, 1999.

JABLOSNKI, J. Padre Nando: um quarup na obra Quarup. 2005, 183 f. Dissertação (Mestrado em Letras - Linguagem e Sociedade) - Universidade Estadual do Oeste do Paraná. - UNIOESTE, Toledo, 2005.

LAFETÁ, J. L., LEITE, L. C. ZILIO, C. O nacional e o popular na cultura brasileira - Artes plásticas e literatura. São Paulo: Brasiliense, 1982.

LEITE, L. C. Antonio Callado: seleção de textos, notas, estudos biográfico, histórico e crítico. São Paulo: Abril Educação, 1982a. 
LERY, J. de. Histoire D'un Voyage en Terre De Brésil. 2.ed. Paris: Bibliothèque Classique, 1994.

Viagem à Terra do Brasil. Belo Horizonte-Itatiaia-São Paulo: Edusp, 1980.

Viagem à Terra do Brasil. Rio de Janeiro: Editora do Exército, 1961.

LUKÁCS, G. Introdução a uma estética marxista. 2.ed. Rio de Janeiro: Civilização Brasileira, 1970.

MAMIZUKA, R. B. O romance engajado na década de 60: Quarup. Campinas, 1983. Dissertação (Mestrado) - Instituto de Estudos da Linguagem, Universidade Estadual de Campinas, Campinas, 1983.

MARTINELli, M. Antonio Callado: um sermonário à brasileira. São Paulo: Annamblume, 2006.

MATOS, G. Poemas escolhidos. Seleção, introdução e notas de José Miguel Wisnik. São Paulo: Cultrix, 1976.

PELLEGRINI, T. Relíquias da casa velha: literatura e ditadura, 50 anos depois. Revista Estudos de Literatura Brasileira Contemporânea. n. 43, 2014.

PORTELA, C. de A. Por uma história mais antropológica: indígenas na contemporaneidade. Goiânia: Sociedade e Cultura, 2008.

Relatório da Comissão da Verdade. 2015. Disponível em: $\langle$ http://www.cnv.gov.br/index.php?option=com_content\&view=article\&id=571>

Acesso em: 28 out. 2015.

REIS, C.; LOPES, A. C. M. Dicionário de teoria da narrativa. São Paulo: Ática, 1988.

RIBEIRO, D. Gentilidades. São Paulo: LPM, 2011.

RIDENTI, M. A guerrilha de Antônio Callado. In: KUSHNIR, B. (org.). Perfis cruzados: trajetórias e militância política no Brasil. Rio de Janeiro: Imago, 2002.

SANTOS, L. A. O. dos. O percurso da indianidade na literatura brasileira: matizes da figuração. São Paulo: Cultura Acadêmica, 2009b.

SCHWARZ, R. Ao vencedor as batatas: forma literária e processo social nos inícios do romance brasileiro. 5.ed. São Paulo: Duas Cidades/Editora 34, 1992.

SILVA, L. G. A.; SANTANA, J. A.; BELTRÃO, L. C. Aspectos da construção da imagem do índio na narrativa Quarup, de Antonio Callado. v. 3. Ponta Grossa: Muitas Vozes, 2014. 
SÜSSEKIND, F. O escritor como genealogista: a função da literatura e a língua literária no romantismo brasileiro. In: PIZARRO, A. (org). América Latina: palavra, literatura e cultura. São Paulo/Campinas: Memorial/Unicamp, 1993.

TELLES, G. M. (org.). Prefácios de romances brasileiros. Porto Alegre: Academia, 1986.

VERÍSSIMO, J. História da Literatura Brasileira: de Bento Teixeira (1601) a Machado de Assis (1908). São Paulo: Letras \& Letras, 1998.

VILLAS-BÔAS, C. O. Xingu: os contos de Tamoin. São Paulo: Kuarup, 2000. 